CHLORINATED ORGANIC COMPOUNDS IN GROUND WATER AT ROOSEVELT FIELD, NASSAU COUNTY, LONG ISLAND, NEW YORK

by David A. V. Eckhardt and Kenneth A. Pearsall

U.S. GEOLOGICAL SURVEY

Water-Resources Investigations

Report 86-4333

Prepared in cooperation with the NASSAU COUNTY DEPARTMENT OF PUBLIC WORKS

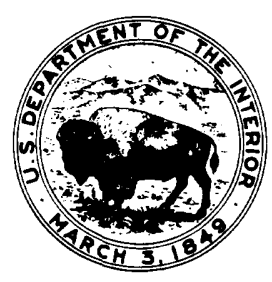

Syosset, New York

1989 
DEPARTMENT OF THE INTERIOR

DONALD PAUL HODEL, Secretary

U.S. GEOLOGICAL SURVEY

Dallas L. Peck, Director

For further information call:

U.S. Geological Survey Water Resources Division 5 Aerial Way

Syosset, New York 11791
Copies of this report may be obtained from:

U.S. Geological Survey Books and Open-File Reports Section Federal Center, Bldg. 41 Box 25425

Denver, CO 80225 


\section{CONTENTS}

Page

Abstract. . . . . . . . . . . . . . . . . . . . . . . 1

Introduction. . . . . . . . . . . . . . . . . . . . . . . . . . 1

Purpose and scope. . . . . . . . . . . . . . . . . . . 3

Location and description of the Roosevelt Field area . . . . . . 4

Methods of study . . . . . . . . . . . . . . . . . . . 4

Well network and sampling procedures. . . . . . . . . . 5

Chemical analyses... . . . . . . . . . . . . . . 8

Quality assurance... . . . . . . . . . . . . . . 9

Accuracy of measurements. . . . . . . . . . . . . . . 9

Acknowledgments. . . . . . . . . . . . . . . . . . . . . 9

Hydrogeologic setting . . . . . . . . . . . . . . . . . . . 10

Magothy aquifer. . . . . . . . . . . . . . . . . . . 11

Upper glacial aquifer. . . . . . . . . . . . . . . . . . 11

Hydrologic environment. . . . . . . . . . . . . . . . . . 11

Precipitation. . . . . . . . . . . . . . . . . . . 11

Water use. . . . . . . . . . . . . . . . . 12

Recharge . . . . . . . . . . . . . . . . . 15

Recharge basins.................... 15

Drain field . . . . . . . . . . . . . . 15

Diffusion wells.................. . 16

Ground-water movement. . . . . . . . . . . . . . . . 16

Upper glacial aquifer . . . . . . . . . . . . . . . 16

August 1982 water table. . . . . . . . . . . . 17

August 1983 water table. . . . . . . . . . . 20

August 1984 water table. . . . . . . . . . . 20

Magothy aquifer... . . . . . . . . . . . . . . 21

Downward movement of water in the aquifer system. . . . . . 21

Inorganic chemical constituents in ground water. . . . . . . . 23

Ground-water temperature . . . . . . . . . . . . . . . 25

Volatile organic compounds in ground water. . . . . . . . . . . . 25

Chemical character.................... . 25

Concentrations at Roosevelt Field. . . . . . . . . . . . 26

Trichloroethylene (TCE), 1,2-dichloroethylene, and tetrachloro-

ethylene in discharged cooling water. . . . . . . . . . . 26

Discharge to Pembrook recharge basin. . . . . . . . . . 27

Discharge to Garden City Plaza drain field. . . . . . . . 27

TCE in the upper glacial aquifer . . . . . . . . . . . . 29

Original plume. . . . . . . . . . . . . . . . . . 29

Plume at Garden City Plaza drain field. . . . . . . . . . 29

Plume at Pembrook recharge basin. . . . . . . . . . . 30

Extent of TCE contamination . . . . . . . . . . . . . . 31

TCE in the Magothy aquifer... . . . . . . . . . . . . . . 33

Movement of TCE. . . . . . . . . . . . . . . . . . . . 35

Advection . . . . . . . . . . . . . . 36

Upper glacial aquifer. . . . . . . . . . . . . 36

Magothy aquifer................ 36

Density-induced movement. . . . . . . . . . . . . 37

Biodegradation. . . . . . . . . . . . . . . 37

Adsorption. . . . . . . . . . . . . . . . . 38

Summary and conclusions... . . . . . . . . . . . . . . . 39

References cited. . . . . . . . . . . . . . . . . . . . 42 


\section{ILLUSTRATIONS}

Page

Figure 1. Map of Nassau County showing location of Roosevelt Field. . 2

2. Photographs showing Roosevelt Field area:

A. December 1951. B. December 1974 . . . . . . . . . 6

3. Idealized north-south geologic section through Nassau

County. . . . . . . . . . . . . . . . . 10

4. Bar graph showing monthly precipitation at Mineola, N.Y.,

during 1982-84 water years. . . . . . . . . . 12

5. Map showing location of pumping centers and areas of cooling-water discharge at Roosevelt Field in 1983. . . . 14

6. Bar graph showing total monthly pumpage from four publicsupply wells at Roosevelt Field during 1983 water year. . . 14

7. Maps showing water-table configuration at Roosevelt Field:

A. August 1982. B. August 1983. C. August 1984 . . . 17-19

8. Hydrograph showing water-table altitudes at wells $N 9955$ near Pembrook recharge basin and N9958 near Garden City Plaza from August 1982 through January 1983 . . . . . . 20

9. Hydrographs showing water-level fluctuations at wells N9955 and N10020 near southwest corner of shopping center in fall 1982 and winter 1983. . . . . . . . . . . .

10. Maps showing trichloroethylene concentrations in the upper glacial aquifer at Roosevelt Field: A. August-September

1983. B. April-May 1984 . . . . . . . . . . . . . . 32-33

11. Map showing trichloroethylene concentrations in the Magothy aquifer at Roosevelt Field, April-May 1984, before

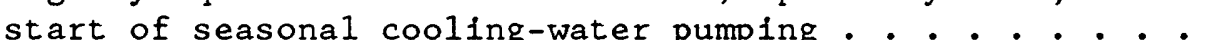

\section{TABLES}

Table 1. List of volatile organic compounds analyzed for in groundwater samples from Roosevelt Field, 1983-84 . . . . . . . .

2. Annual pumpage from 11 public-supply wells in the Roosevelt Field area. . . . . . . . . . . . . . . . 14

3. Summary of inorganic chemical analyses of ground water from wells in the Roosevelt Field area of Nassau County, 1984. . . 


\section{TABLES (Continued)}

Table 4. Concentration and discharge of volatile organic compounds in water from six cooling-water wells at Roosevelt Field, August 1984 . . . . . . . . . . . . . . . . 28

5. Total organic carbon in core samples from we11 N10042 at Mitchel Field in central Nassau County, New York. . . . . . 38

6. Data on we1ls in the Roosevelt Field area, Nassau County, New York. . . . . . . . . . . . . . . . .

7. Concentrations of volatile organic compounds in ground-water samples collected by Nassau County before 1983. . . . . . .

8. Concentrations of volatile organic compounds in ground-water samples collected by U.S. Geological Survey in 1983-84. . . .

\section{PLATES}

(in pocket)

Plate 1. Map showing 1983 water-table altitude in April 1984 and locations of wells in the Roosevelt Field area

2. Geologic sections $A-A^{\prime}, B-B^{\prime}, C-C^{\prime}, D-D^{\prime}$, and $E-E^{\prime}$ showing 1984 trichloroethylene concentrations in the Roosevelt Field area

\section{CONVERSION FACTORS AND ABBREVIATIONS}

For the conventence of readers who prefer metric (International System) units rather than the inch-pound units used in this report, the following conversion factors may be used:

Mult 1ply inch-pound unit

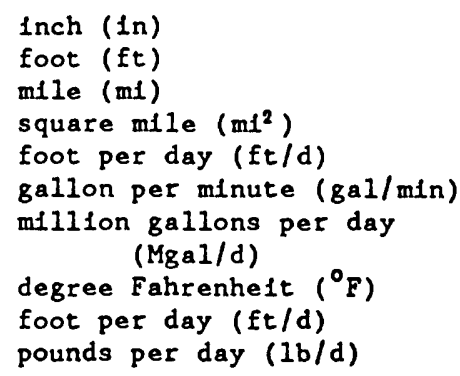

by

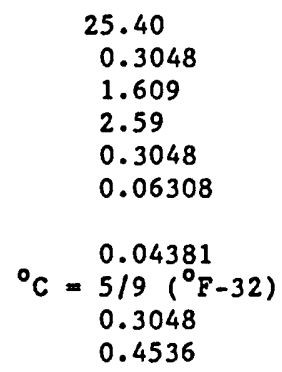

To obtaln metric unit

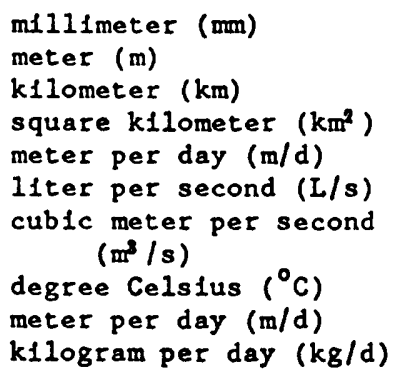

Sea level: In this report "sea level" refers to the National Geodetic Vertical Datum of 1929 (NGVD of 1929)--a geodetic datum derfved from a general adjustment of the flrst-order level nets of both the Unfted States and Canada, formerly called "sea level datum of 1929." 


\title{
CHLORINATED ORGANIC COMPOUNDS IN GROUND WATER AT ROOSEVELT FIELD, NASSAU COUNTY, LONG ISLAND, NEW YORK
}

\author{
by David A. V. Eckhardt and Kenneth A. Pearsall
}

\begin{abstract}
Trichloroethylene, 1,2-dichloroethylene, and tetrachloroethylene have been detected in ground water at Roosevelt Field near Garden City, N.Y. The 200-acre area was once an air field but is now a large shopping mall and office-building complex. One well screened $300 \mathrm{ft}$ below land surface in the Magothy aquifer (Upper Cretaceous) has yielded water that contains 38,000 micrograms per liter of trichloroethylene, the principal contaminant. The source(s) of contamination have not been identified.

During 1982-84, four public-supply wells at Roosevelt Field pumped more than 4 million gallons per day for peak water demand in the summer, and seven wells pumped an additional 4 million gallons per day for warm-weather cooling. Four of the cooling-water wells pumped water from trichloroethylene-contaminated zones in the Magothy aquifer. The cooling water was discharged after use to the water-table (upper glacial) aquifer through a recharge basin and a subsurface drain field.

Three plumes of contaminated ground water have been delineated. The initial plume probably originated before the shopping center was developed and extends through both the upper glacial and Magothy aquifers; the other two plumes are in the upper glacial aquifer and originate at the two cooling-waterdischarge sites. The contaminated discharge water moves radially away from both discharge sites, and the two secondary plumes have merged in the southwestern part of Roosevelt Field. In 1986, the plumes extended at least 1,000 feet south-southwest beyond Roosevelt Field along the regional ground-water flow path. Concentrations of inorganic constituents in the plumes are indistinguishable from those in the ambient ground water.

Ground-water velocity in the Magothy aquifer varies locally because the aquifer is anisotropic and heterogeneous, and because large-scale pumping increases the hydraulic gradients locally. Where clay layers are absent and sandy zones provide good vertical hydraulic connection between upper and lower parts of the aquifer system, pumping of wells screened in the middle and basal sections of the Magothy aquifer has increased the rates of downward movement of contaminants. As a result, trichloroethylene has been detected in the basal section of the Magothy aquifer, 500 feet below land surface.
\end{abstract}

\section{INTRODUCTION}

Chlorinated organic chemicals in ground water were first discovered in Nassau County in October 1975, when vinyl chloride, trichloroethylene (TCE), and tetrachloroethylene were detected in two industrial-supply wells at Bethpage (fig. 1) (Myott, 1980). A program to sample all public-supply wells 


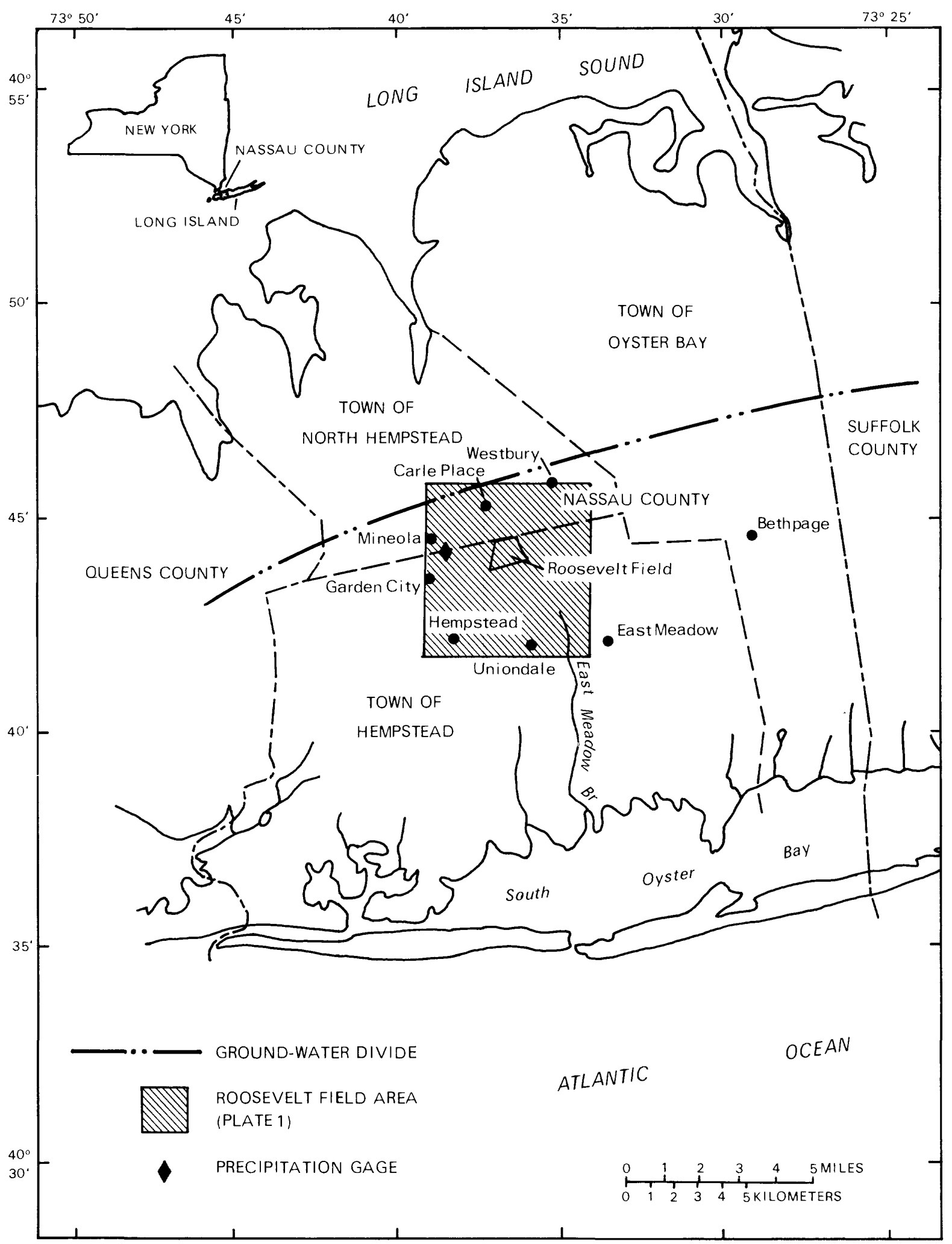

Base from U.S. Geological Survey

State base map. 1974

Figure 1.--Location of Roosevelt Field, Nassau County. 
In Nassau County was begun in November 1976 after similar organic compounds were detected in five public-supply wells in the Bethpage area. Surveys of industrial and commercial establishments were conducted to identify potential sources of organic chemical contamination, such as industrial and commercial sites and chemical-waste-disposal areas (Mackay and others, 1979, p. 1). Organic compounds were commorly detected in the ground-water system in these initial surveys; the higher concentrations were mainly in industrialized areas and in shallow wells.

In 1982, the U.S. Geological Survey began a cooperative study with the Nassau County Department of Public Works to evaluate the occurrence and movement of VOC' $s^{1}$ in ground water at Roosevelt Field--an area in the northern part of the Town of Hempstead (fig. 1) where one public-supply well and five cooling-water-supply wells have yielded water that contained TCE in excess of recommended New York State Health Department drinking-water guidelines (50 $\mu \mathrm{g} / \mathrm{L}$ ). (The public-supply well and two cooling-water wells have been subsequently abandoned.) No sources of the contamination had been identified, and a lack of adequate hydrologic information and inconsistencies in the water-quality data from this area were hindering analysis of the movement and fate of the compounds and their effects on the area's water resources. The investigation was conducted from March 1982 through September 1984.

\section{Purpose and Scope}

This report describes the results of the study, the major objective of which was to delineate the horizontal and vertical distribution and temporal trends of VOC concentrations in the aquifer system at Roosevelt Field. A second objective was to evaluate hydrologic factors that determine the distribution and movement of organic compounds in the ground-water system. Factors considered were natural recharge from precipitation, effects of seasonal ground-water pumping for cooling water and public supply, discharge of used cooling water during summer and early fall to the upper glacial aquifer, hydraulic characteristics and dimensions of the aquifer system, and regional ground-water flow patterns.

Most of the work concerned evaluation of factors that affected the movement of ground water and associated advective movement of dissolved organic chemical compounds. Other factors such as dispersion, biochemical degradation, or volatilization were not studied in detail but are discussed briefly. Most of the sampling was done within Roosevelt Field, but groundwater levels were measured and samples collected from the $10-\mathrm{mi}^{2}$ area surrounding Roosevelt Field (fig. 1 and pl. 1) as well.

This report describes the distribution of chlorinated compounds, primarily TCE, in the ground-water system at Roosevelt Field and discusses factors that affect contaminant movement. Concentrations of TCE, 1,2-dichloroethylene (DCE), and tetrachloroethylene (PCE) in samples from wells in the Roosevelt Field area are reported in tables 7 and 8 (at end of report); table 7 contains data collected by Nassau County before 1983, and table 8 contains data collected in 1983-84 by the Geological Survey. The data in

1 In this report, chlorinated organic compounds are referred to as VOC's (volatile organic compounds). 
table 7 were used to delineate plumes of TCE in the upper glacial aquifer and the Magothy aquifer on two maps. Water-table maps that represent four perlods are given--August 1982, August 1983, April 1984, and August 1984; the reglonal movement of ground water is also described. Five geologic sections ( $p 1.2$ ) show the dimensions and lithology of the aquifer system in the Roosevelt Field area and concentrations of TCE at various depths. An analysis of the effects of seasonal pumping of TCE-contaminated ground water and its discharge after use to the shallow aquifer at two locations also is presented.

\section{Location and Description of the Roosevelt Field Area}

The area addressed in this report encompasses about $20 \mathrm{mi}^{2}$ in central Nassau County and lies on the boundary between the Towns of Hempstead and North Hempstead (fig. 1, pl. 1). Roosevelt Field was a commercial airfield from about 1924 to 1951 (f1g. 2A). (Charles Lindbergh departed from this field on his historic trans-Atlantic flight in 1927). The field is now the site of a large shopping mall and office-building complex and is surrounded by residential and commercial areas and light industry (fig. 2B).

Directly southeast of Roosevelt Field is the site of Mitchel Field, a U.S. Alr Force base until 1957 and currently occupied by Nassau County Community College, Hofstra University, Nassau Veterans Memorial Coliseum, and several other county and commercial facilities ( 1.11$)$. Nassau County is currently developing Mitchel Field and neighboring Eisenhower Park as a water-supply area. VOC's were detected at the northeast corner of the Mitchel Field site during exploratory well drilling by Nassau County in 1978. In one well (N9765, near Mitchel Field, pl. 1), ground water contained total VoC concentrations exceeding $260,000 \mu \mathrm{g} / \mathrm{L}$. The source has been determined to be from a former industrialsolvent-distributor and a State mandated soll and ground-water remedial program has been in-place since 1985. Work by the USEPA has also begun on another former industrial-solvent distributor site directly to the west. The contamination at Mitchel Field is currently under study by Nassau County and others, and, for that reason, the area shaded on plate 1 was excluded from this study.

\section{Methods of Study}

Ground water was sampled by the Geological Survey during late summer 1983 and spring 1984 to (1) delineate the area affected by VOC's; (2) determine the distribution of VOC's in the aquifer system, (3) examine the effect of ground-water pumping and discharge of contaminated cooling water on the movement of contaminants in the area, and (4) provide a measure of background concentrations of VOC's in areas bordering Roosevelt Field. The first set of samples was collected during August and September 1983 at the end of the summer pumping season and included samples from 62 wells in the immediate vicinity of the observed contamination. The second set was collected from April through June 1984, at the beginning of the summer pumping season. The second phase included sampling to provide background water-quality data and entailed a more intensive effort to sample all wells in the Roosevelt Field area, including most public-supply wells and monitoring wells.

In addition to the primary sampling phases in August 1983 and April 1984 , a set of samples was collected in August 1984 from cooling-water wells that 
contributed contaminated water to Pembrook recharge basin and Garden City Plaza drain field. The discharge water from the wells at both locations was sampled concurrently, as was ground water near each discharge point. Additional ground-water samples were collected as necessary near the coolingwater-discharge areas to define seasonal changes in ground-water quality. In a11, 224 water samples were collected from 52 monitoring we11s, 28 publicsupply wells, and 25 cooling-water wells.

\section{Well Network and Sampling Procedures}

A well network consisting of 52 monitoring wells, 28 public-supply wells, and 25 cooling-water supply wells was established within the 10-mi ${ }^{2}$ Roosevelt Field area for collection of hydrogeologic and water-quality data. Most monitoring wells were installed before the study began and therefore represent a variety of casing sizes, construction materials, and installation methods. The monitoring wells typically have either 2- or 4-in steel casings and stainless steel screens. To supplement the well network, seven additional wells were drilled by augering in the upper glacial aquifer, and two more were drilled to the Magothy aquifer by the mud rotary method. Information on wells in the network is given in table 6 (at end of report), and well locations are shown on plate 1 .

The procedures used for monitoring-well sampling depended on the casing diameter and well depth. Most wells screened in the upper glacial aquifer were sampled with a Johnson-Keck ${ }^{1}$ 1.75-in-diameter positive-displacement screw-type submersible pump. The pump is made of stainless steel with an ethylene propylene rubber (EPDM) stator; Teflon ${ }^{1}$ tubing was used to transmit the pumped water to land surface. The usual procedure was to place the pump intake just above the well screen and pump at least 3 casing volumes (about 1 hour) before collecting samples. Pump placement, flow rate, and pumping duration were duplicated when wells were resampled. Tests of this sampling procedure have indicated that it provides representative samples of ground water at VOC concentrations between 1 and $1,000 \mu \mathrm{g} / \mathrm{L}$ (Pearsa11 and Eckhardt, 1987). The pump was flushed after each sampling with 2 to 5 gal of clean tap water. Samples of flush water were collected after sampling and analyzed by purge-and-trap liquid-sample concentration and gas chromatography with flame-ionization detection (PT-GC/FID) scans for volatile compounds to verify the cleanliness of the sampling equipment. Permanent pump installations were used to collect samples for water-quality analyses at public-supply and cooling-water wells.

Field data recorded during pumping included initial water leve1, pump-intake depth, pumping time, flow rate, and drawdown. Specific conductance, $\mathrm{pH}$, and temperature of all samples were measured during sampling; dissolved oxygen concentrations (DO) were measured in selected samples.

Four-inch-diameter wells deeper than $100 \mathrm{ft}$ were evacuated and sampled with a 4-inch-diameter Goulds 1-hp submersible pump. Water was transmitted to the surface through 1.25-inch (outside diameter) Teflon pipe and sampled at the well head. The procedures used and precautions taken were similar to

1 Use of the brand name in this report is for identification purposes only and does not constitute endorsement by the U.S. Geological Survey. 


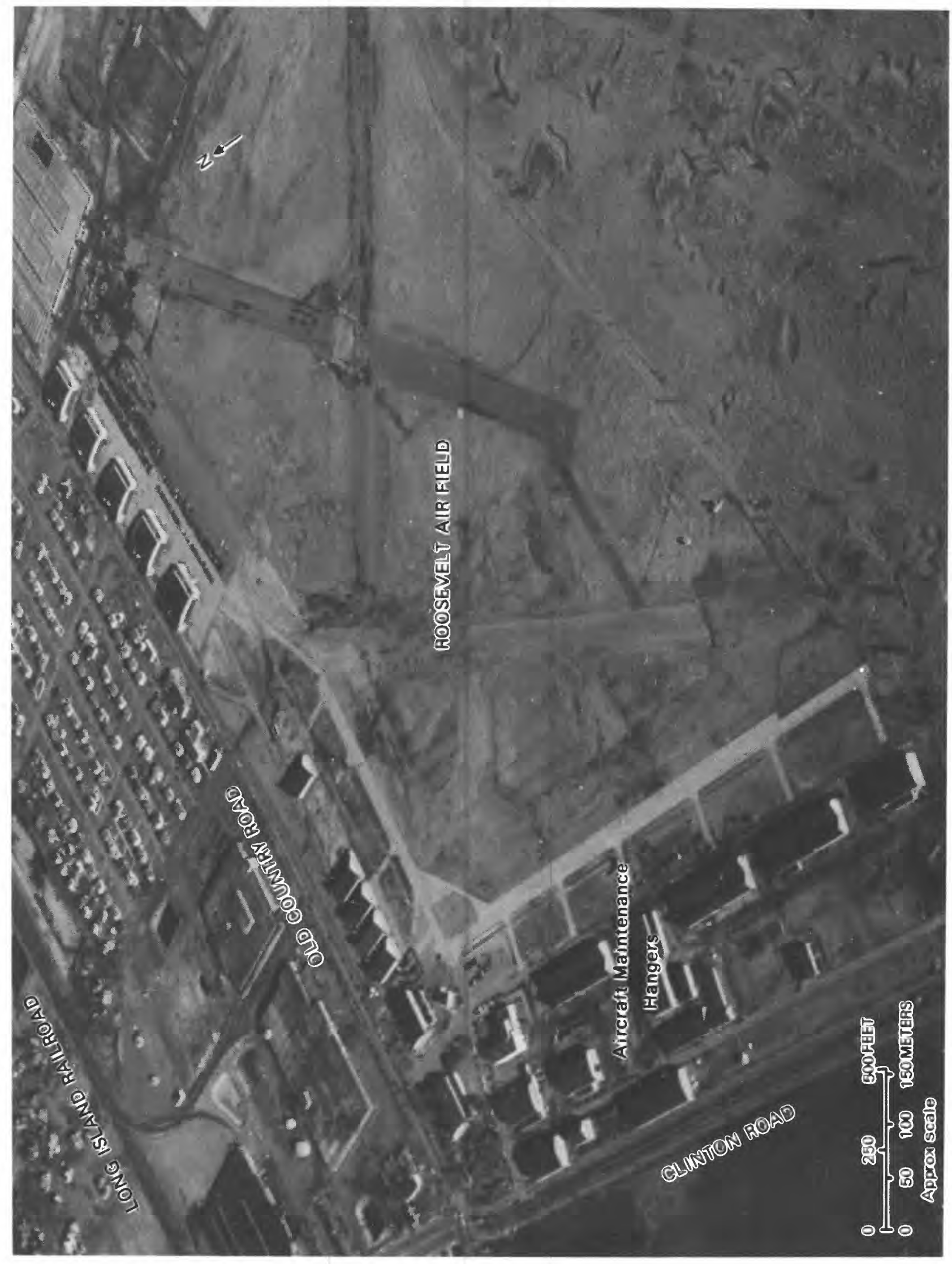




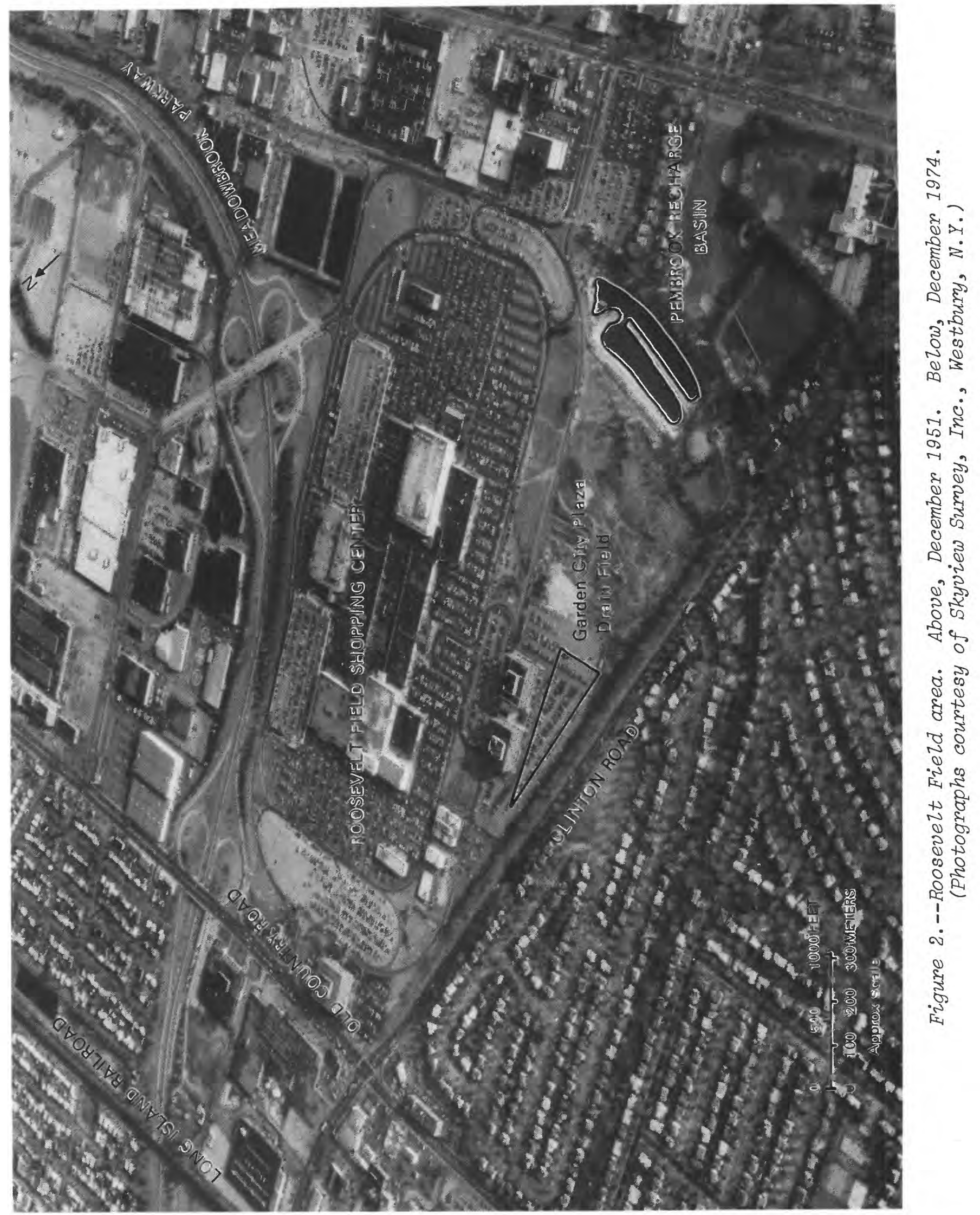


those used with the 1.75-inch submersible pump. Wells with a casing diameter of less than 2 inches were sampled with bottom-entry Teflon bailers. Sampling equipment and techniques are described and evaluated by Pearsall and Eckhardt (1987). Production wells with permanently installed pumps such as publicsupply wells or cooling-water wells were sampled at a tap or faucet as near the well head as possible after the pump had been running at least 1 hour.

Sample containers were prepared and supplied by the analyzing laboratory. Samples for VOC analysis were collected in glass bottles and sealed with Teflon-lined caps or septa. These sample containers were filled with minimum aeration of the sample; this was usually done by routing sample water from the pump outlet into the sample container through a Teflon tube whose exit end was below the water surface in the sample container. All samples for inorganicconstituent analysis were collected in containers supplied with preservatives added by the analyzing laboratory. Samples for dissolved inorganic constituents were filtered through a $0.45-\mu \mathrm{m}$ cellulose-membrane filter. Samples for metals analysis were preserved with nitric acid. All samples were stored in a cooler with ice for preservation after collection.

\section{Chemical Analyses}

The VOC's analyzed for in this investigation are listed in table 1. Trichloroethylene, cis-1,2-dichloroethylene, and tetrachloroethylene were the principal compounds detected in most water samples. Concentrations of these constituents before and during this study are given at the end of this report in tables 7 and 8, respectively. Total VOC's (the sum of concentrations for all compounds listed in table 1) are included. A summary of the concentrations of inorganic chemical constituent and physical-property values are listed in table 3 (p. 24). Samples were analysed by the Nassau County Department of Health, Division of Laboratories and Research, in Hempstead, N.Y., by procedures described in Narang and Bush (1980) and the U.S. Environmental Protection Agency (1979a).

Table 1.--List of volatile organic compounds analyzed for in ground-water samples from Roosevelt Field, 1983-84.

\section{Volatile Halogenated Compounds}

Trichlorofluoromethane

Methylene chloride

1,1,2-Trichlorotifluoroethane

1,1-Dichloroethylene

cis-1,2-Dichloroethylene

trans-1,2-Dichloroethylene

1,1-Dichloroethane

Chloroform

1,1,1-Trichloroethane

Carbon tetrachloride

Trichloroethylene

Bromodichloromethane

cis-1,3-Dichloropropene

Dibromochloromethane

1,1,2-Trichloroethane

1,2-Dibromomethane
Tetrachloroethylene

Bromoform

1,2-Dichloroethane

1,2-Dichloropropane

trans-1, 3-Dichloropropene

$1,1,2,2$-Tetrachloroethane

Volatile Aromatic Compounds

Benzene

Toluene

Chlorobenzene

Ethylbenzene

Xylene

Dichlorobenzene 


\section{Quality Assurance}

All samples to be analyzed for VOC's were collected in duplicate and screened by PT-GC/FID' scans at the U.S. Geological Survey's Long Island office for comparision with the reporting laboratory's results. Flush blanks of rinse water from the 2-inch submersible pump were also screened to verify the cleanliness of the sampling equipment between samples. Ten percent of the VOC samples were collected in triplicate, one of which was analysed by the U.S. Geological Survey National Water-Quality Laboratory (NWQL) in Atlanta, $\mathrm{Ga}$., by procedures described by Wershaw and others (1982). Surrogate spiking compounds were added to these samples by NWQL analysts before analysis to evaluate recovery efficiencies. Ten percent of samples for inorganic analysis were collected in duplicate and analyzed by the NWQL by the procedures described by Skougstad and others (1979). Both the Nassau County Department of Health Laboratory and the U.S. Geological Survey National Water Quality Laboratory participate in the Standard Reference Water Sample Program, a quality-assurance program administered by the U.S. Geological Survey.

\section{Accuracy of Measurements}

A degree of error is inherent in any measurement, and an understanding of the possible magnitude of the error is necessary to correctly interpret that measurement. Several possible sources of error are inherent in the process of ground-water sampling and analysis.

A primary source of analytical error arises from variable recovery efficiencies of very low concentrations of organic constituents from aqueous solutions. Acceptable recovery efficiencies for extraction of surrogate spiking compounds from water samples can range from 70 to 130 percent (Wershaw and others, 1982).

In addition to the inherent potential for error in analytical techniques, the quality of data depends on the ability of the field procedures to provide a sample that is truly representative of the aquifer water. The uncertainty in obtaining representative samples and in preserving them may add a degree of error, even before the sample enters the laboratory. Thus, despite rigid quality-control procedures, specific concentrations reported as representative of aquifer water at a site must be interpreted with caution.

\section{Acknow ledgments}

This work was done by the U.S. Geological Survey as part of a cooperative study with Nassau County. J. F. Mulligan, P. J. Witkowski, and R. E. Denton of the Nassau County Department of Public Works helped in locating and drilling wells, coordinating vertical elevation surveys, and furnishing water levels and geophysical data. M. J. Alarcon, D. H. Myott, and J. J. Kardos of the Nassau County Health Department (NCHD), Bureau of Public Water Supply, assisted by implementing a project with the New York State Health Department

1 Purge and trap liquid-sample concentration followed by gas chromatography with flame-ionization detection. 
that provided for the drilling of 18 observation wells and sampling of publicsupply wells. James Adamski, Andrew Lichtman, and Robert Porter, NCHD, Division of Laboratories and Research, coordinated the analytical laboratory services. Many private well owners and officials from water-supply departments for the Town of Hempstead, the villages of Garden City, Mineola, and Hempstead, and the water districts of Carle Place and Westbury provided access to their wells and records. B. J. Schneider of the U.S. Geological Survey did the preliminary data collection at Roosevelt Field.

\section{HYDROGEOLOGIC SETTING}

The Long Island aquifer system lies within the embayed section of the Atlantic Coastal Plain province. The island is underlain by unconsolidated Pleistocene and Cretaceous deposits of gravel, sand, silt, and clay that overlie gently dipping metamorphic and igneous Precambrian bedrock (fig. 3 ). The hydrogeology of Nassau County is discussed in detail by McClymonds and Franke (1972), Isbister (1966), Perlmutter and Geraghty (1963), Swarzenski (1963), Kilburn (1979), and Kilburn and Krulikas (1987).

The aquifer system in the study area consists, from oldest to youngest, of the Lloyd aquifer, which is the lower member of the Raritan Formation of Cretaceous age and rests on bedrock; the Upper Cretaceous Magothy aquifer, which is the principal aquifer for water supply in this area; and the Pleistocene upper glacial aquifer, which contains the water table. The

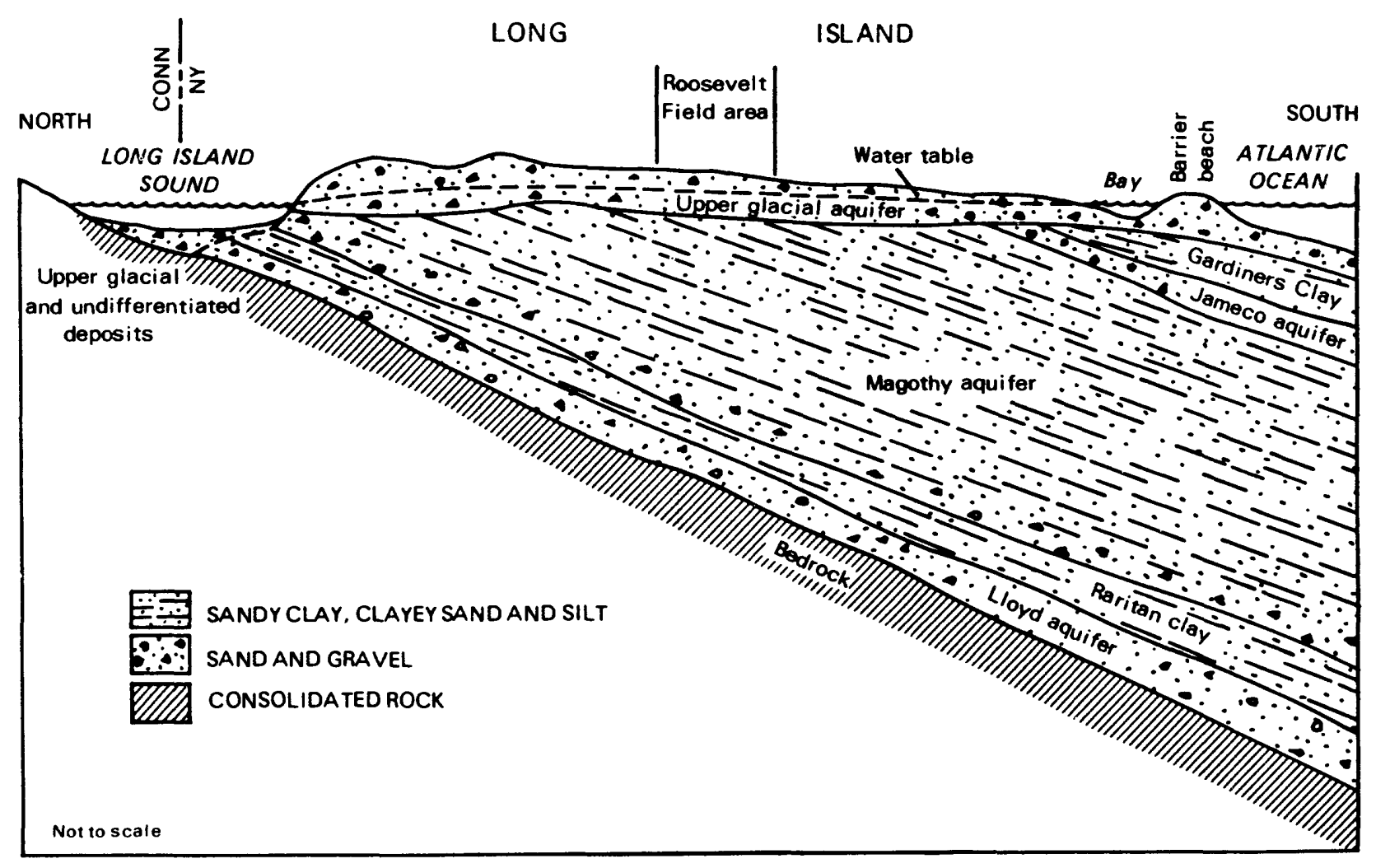

Figure 3.--Idealized north-south geologic section through Nassau County. (Modified from McClymonds and Franke, 1972.) 
Raritan confining unit, the upper member of the Raritan Formation, consists mostly of clay and sandy clay and separates the Lloyd aquifer from the Magothy aquifer. South of the Roosevelt Field area, the Gardiners Clay (Pleistocene age) and other confining units separate the Magothy and upper glacial aquifers, but these units do not extend into the study area. Thus, the upper glacial aquifer at Roosevelt Field is in direct hydraulic contact with the Magothy aquifer. The upper zones of the aquifer system in the Roosevelt Field area are depicted in five geologic sections in plate 2; the sections were compiled from deep-well logs. This study concerned only the aquifer system above the Raritan confining unit (fig. 3 ) because no hydrologic or water-quality data from below the confining unit in this area were available.

\section{Magothy Aquifer}

The Magothy aquifer unconformably overlies the Raritan confining unit and consists of alternating sequences and gradations of sand, clayey sand, sandy clay, clay, lignite, and some gravel in the basal section. The deposits are fluvial deltaic and have considerable lateral and vertical heterogeneity. Although the Magothy aquifer is about $500 \mathrm{ft}$ thick in the Roosevelt Field area, most of the public-supply water is taken from sand and gravel zones in the lower $150 \mathrm{ft}$. Discontinuous layers of gray lignitic clay are common in the upper zones, and the larger ones form local confining layers.

Hydraulic conductivity averages between 50 and $60 \mathrm{ft} / \mathrm{d}$ in southern Nassau County but may be as much as $190 \mathrm{ft} / \mathrm{d}$ in the basal section of the Magothy aquifer, which contains more gravel than the upper sections (McClymonds and Franke, 1972).

\section{Upper Glacial Aquifer}

The upper glacial (water-table) aquifer unconformably overlies the Magothy aquifer and consists of glacial outwash that is predominantly sand and gravel. The outwash deposits in the Roosevelt Field area are fairly uniform in particle-size distribution and lithology. Depth to water ranges from 25 to $50 \mathrm{ft}$ below land surface, and the saturated thickness of the aquifer ranges from 20 to $40 \mathrm{ft}$. Hydraulic conductivity of the upper glacial aquifer in southern Nassau County averages about $250 \mathrm{ft} / \mathrm{d}$ (McClymonds and Franke, 1972).

\section{HYDROLOGIC ENVIRONMENT}

\section{Precipitation}

Precipitation is the only natural source of freshwater to the groundwater reservoir of Long Island. Annual precipitation in the Roosevelt Field area averages about 42 inches and is fairly well distributed throughout the year (Miller and Frederick, 1969). Nearly half the annual precipitation is returned to the atmosphere by evapotransporation; the remainder infiltrates the earth's surface and percolates downward to the water table as recharge to the ground-water system (Cohen and others, 1968). Direct runoff of 
precipitation from paved areas is routed to recharge basins, which are excavations in the upper glacial deposits from which water infiltrates fairly rapidly into the ground. Direct runoff to streams from precipitation is negligible in the Roosevelt Field area.

Monthly precipitation measured at Mineola (fig. 1) from October 1982 through September 1984 is plotted in figure 4; the bar graph shows that precipitation exceeded the 45-year mean annual precipitation of 43.63 inches during all 3 years of this study. Water year 1984 was particularly wet, especially during the spring.

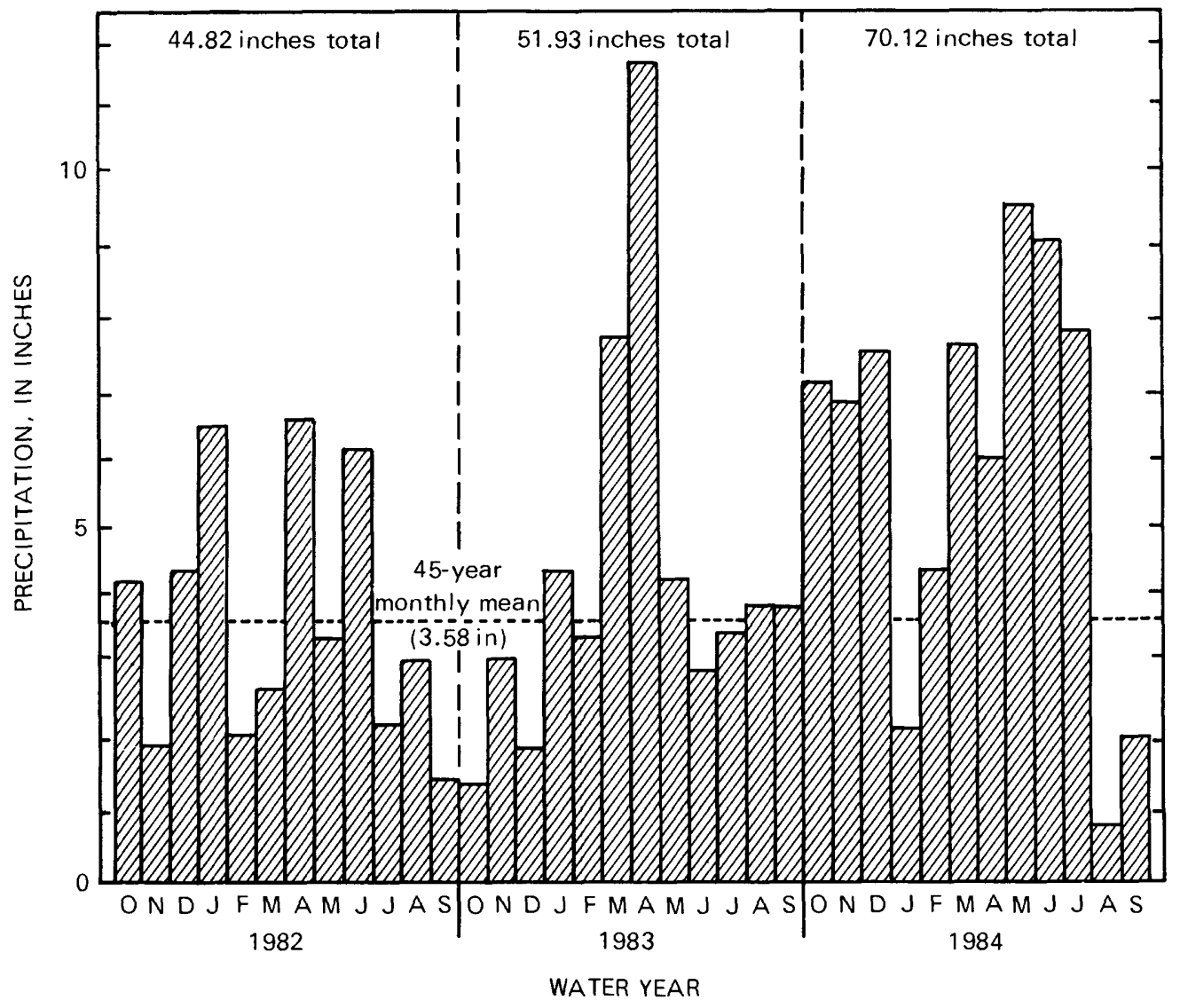

Figure 4.--Monthly precipitation at Mineola, N.Y., during 1982-84 water years.

\section{Water Use}

Annual pumpage from 11 public-supply wells in the Roosevelt Field area is given in table 2; well locations are shown in figure 5 and plate 1.

Four public-supply we1ls (N3934, N3935, N5484, and N5485) and seven cooling-water wells (N5507, N6045, N8050, N8068, N8458, N9310, and N9311) pump water from the Magothy aquifer at Roosevelt Field. The public-supply wells may operate all year, but the peak demand for water during summer causes higher pumpage rates from June through September (fig. 6). Daily summer pumpage from the four public-supply wells may exceed $4 \mathrm{Mgal} / \mathrm{d}$ during hot, dry 
weather. Cooling-water wells operate seasonally 12 to 16 hours per day during warm weather (May-September) and are generally off during cool weather, although wel1 N8458, at the northeast end of the shopping mal1, operates intermittently throughout the year. Combined pumpage from the seven coolingwater wells during the cooling season was about $4 \mathrm{Mgal} / \mathrm{d}$ in 1984.

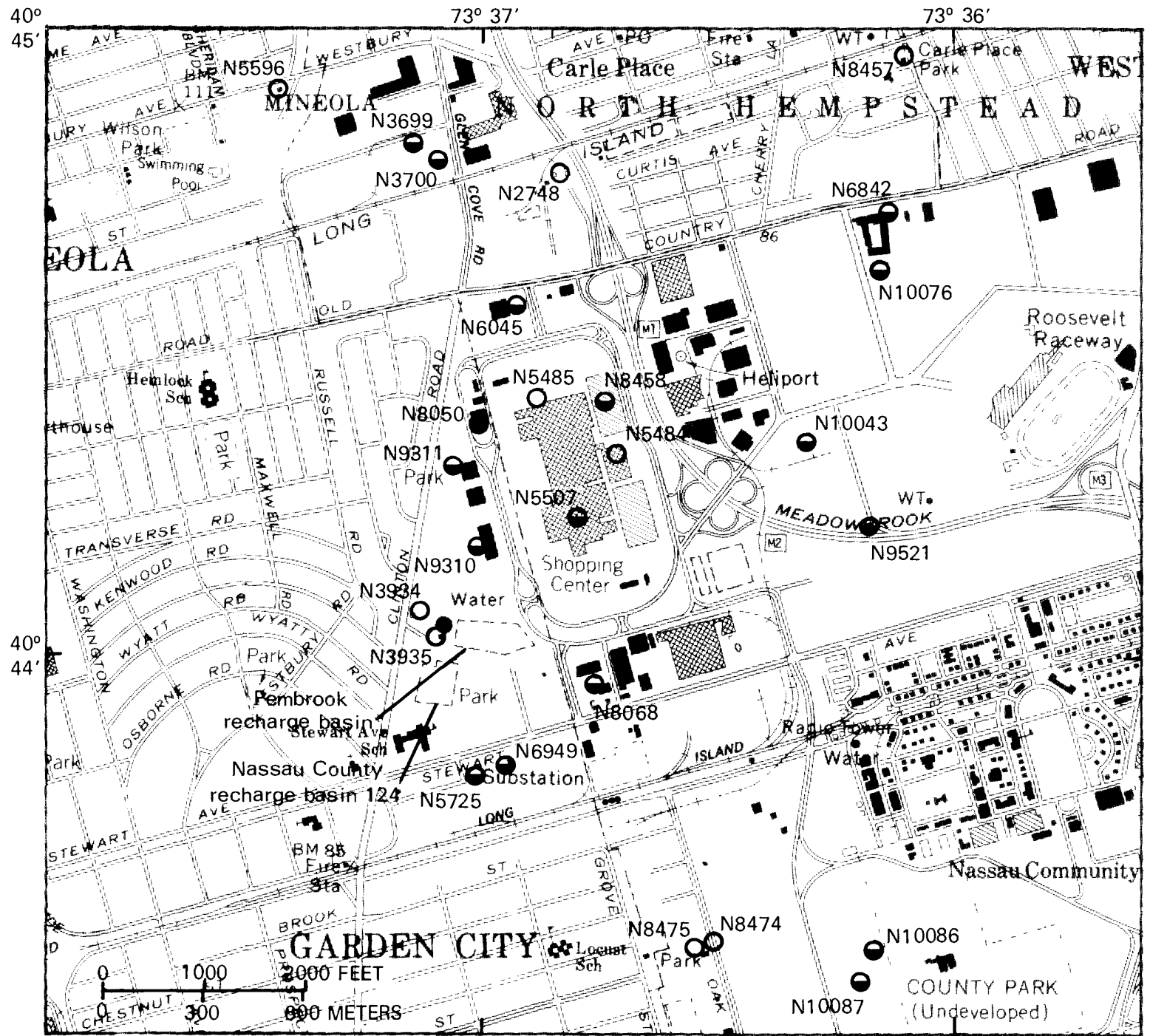

Base from NYSDOT, Freeport, NY, 1981; Lynbrook, NY, 1981;

Sea Cliff, NY, 1981; and Hicksville, NY, 1981, 1:24,000

EXPLANATION

O PUBLIC-SUPPLY WELL

COOLING-WATER WELL

Figure 5.--Location of pumping centers and areas of cooling-water discharge at Roosevelt Field in 1989. Prior to 1985, cooling-water wells N5507, N6045, N8050, and N8458 discharged used water to Pembrook basin; wells N9910 and N9S11 continue to discharge used water to Garden City Plaza drain field. 
Table 2.--Annual pumpage from 11 public-supply wells in the Roosevelt Field area.

[Well locations are shown in pl. 1; data from pumpage records supplied by local water departments]

\begin{tabular}{|c|c|c|}
\hline \multirow{2}{*}{$\begin{array}{l}\text { Well } \\
\text { number }\end{array}$} & \multicolumn{2}{|c|}{ Pumpage, in thousands of gallons } \\
\hline & $\begin{array}{c}\text { Water year* } \\
1982\end{array}$ & $\begin{array}{c}\text { Water year } \\
1983 \\
\end{array}$ \\
\hline N2748 & 126,051 & 157,123 \\
\hline N3934 & 217,903 & 246,824 \\
\hline N3935 & 241,197 & 256,208 \\
\hline N5484 & 114,742 & 140,334 \\
\hline N5485 & 102,713 & 100,986 \\
\hline N5596 & 251,226 & 183,047 \\
\hline N7957 & 209,399 & 272,453 \\
\hline N8457 & 165,033 & 163,993 \\
\hline N8474 & 238,044 & 244,302 \\
\hline N8475 & 255,218 & 239,570 \\
\hline N9521 & 203,877 & 331,299 \\
\hline Total & $2,125,403$ & $2,336,139$ \\
\hline
\end{tabular}

* Water year is the 12 -month period from October 1 of the previous year through September 30 of the indicated year.

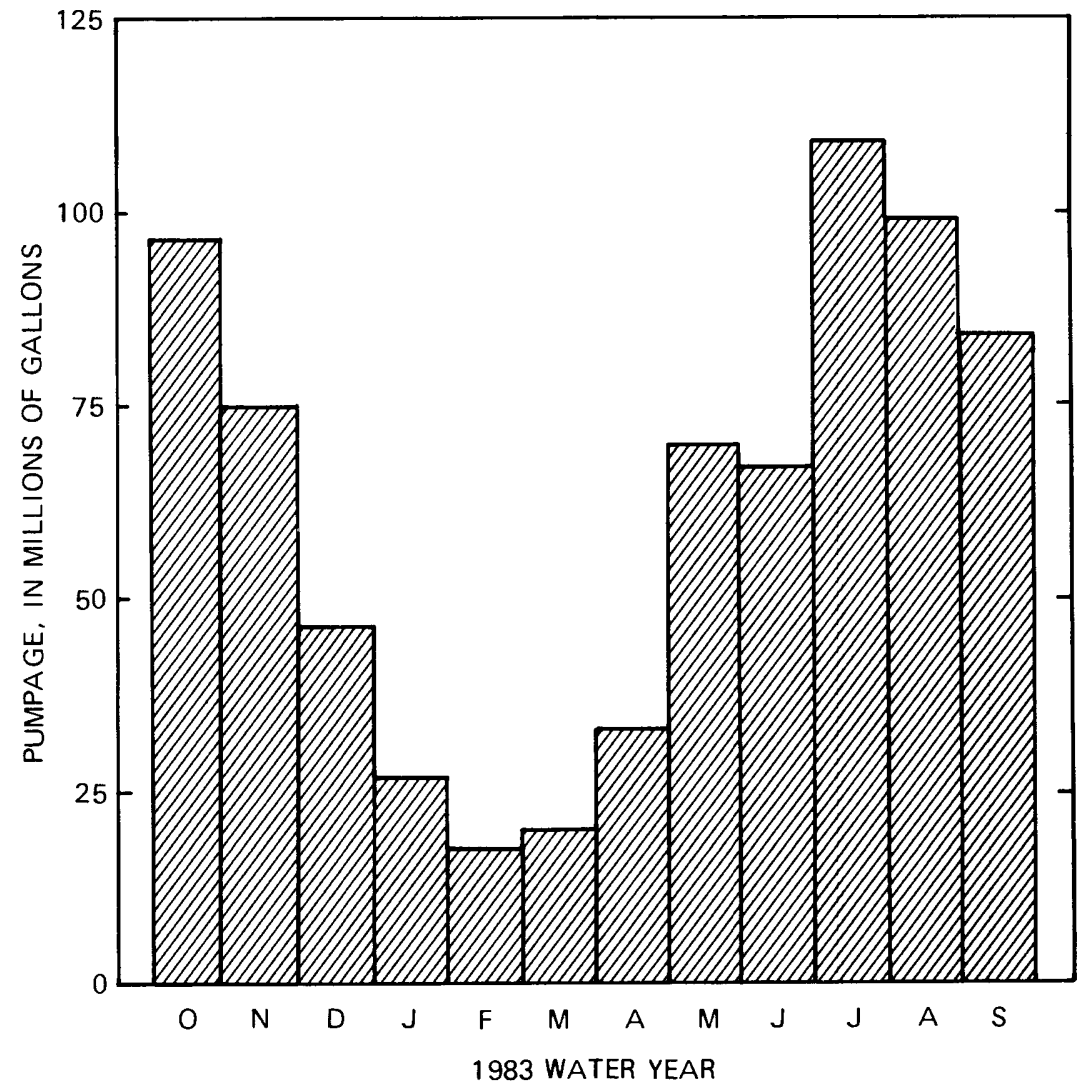

Figure 6.

Total monthly pumpage from four publicsupply wells at Roosevelt Field during 1989 water year. (Data from daily pumpage records supplied by local water departments.) 


\section{Recharge}

Most of Roosevelt Field is paved and impervious; thus, natural recharge of the underlying ground-water system is limited to small grassy areas around the perimeter of the shopping center. Storm drains receive runoff from some of the impervious areas and route it to recharge basins; storm drains in paved parking areas are open to the underlying deposits, which allows direct infiltration. When a storm drain's infiltration capacity is exceeded, overflow conduits carry the excess runoff to local recharge basins. The sporadic recharge from precipitation causes short-term rises of the water table and also causes changes in ground-water quality because the storm runoff differs from ground water, which in some areas at Roosevelt Field is contaminated by VOCs.

Disposal of used cooling water from the seven cooling-water wells provides additional recharge to the ground-water system during the cooling season, typically May through September. During 1982-84, used water from four of the wells was discharged to the upper glacial aquifer at a pair of recharge basins, and water from two wells was discharged to a drain field. Water from the other well was discharged to a series of diffusion wells. Locations of discharge sites, described below, are shown in figure 5 .

\section{Recharge Basins}

Two recharge basins at the southwest corner of Roosevelt Field (fig. 5) received about $2 \mathrm{Mgal} / \mathrm{d}$ from four cooling-water wells (N5507, N6045, N8050, N8458 in p1. 1) in 1982-84 as well as public-supply water from the coolingwater-distribution system during summer. The discharge water was contaminated with VOC's pumped from the intermediate depths of the Magothy aquifer, principally at wells $\mathrm{N} 5507$ and N8050. The recharge basin that received most of the water, referred to herein as Pembrook recharge basin, is privately owned and is divided by an earth dam into halves that are hydraulically connected by a concrete channel. The basin covers 2.5 acres, is excavated in the outwash deposits, has an overflow outlet, and forms a perennial impoundment of water. During the 1983 summer, as much as $0.8 \mathrm{Mgal} / \mathrm{d}$ of water overflowed and entered the second basin, Nassau County stormwater basin 124 (fig. 5). Thus, about $1.2 \mathrm{Mgal} / \mathrm{d}$ infiltrated Pembrook recharge basin as a result of cooling-water discharge during hot weather, and the remaining 0.8 $\mathrm{Mgal} / \mathrm{d}$ infiltrated the Nassau County basin. Stormwater runoff also entered both basins intermittently throughout the year.

\section{Drain Field}

The drain field is excavated in the outwash deposits beneath the parking area at an office-building complex north of the recharge basins, as shown in figure 5. It was built in 1982 on the west side of Roosevelt Field adjacent to the Garden City Plaza office buildings and receives about $2 \mathrm{Mgal} / \mathrm{d}$ of cooling water from Magothy aquifer wells N9310 and N9311 during warm weather. Water from these wells is also contaminated by VOC's but is treated by aeration to reduce the concentrations before it is discharged to the drain field. 
Before the drain field was constructed in 1982, untreated cooling water from wells $\mathrm{N} 9310$ and $\mathrm{N} 9311$ was discharged to the Pembrook recharge basin. The drain field was constructed to allow diversion of this contaminated water from the basin, which reduced the overflow from Pembrook recharge basin into Nassau County recharge basin 124. Treatment of the water before discharge to the upper glacial aquifer at the drain field entails percolation through a column of plastic baffles in contact with forced air, which strips volatile constituents from the water. During the summer cooling season, about 1.2 Mgal/d is treated and discharged to the drain field.

\section{Diffusion Wells}

The diffusion wells are in the southern part of Roosevelt Field and recelve about $0.8 \mathrm{Mgal} / \mathrm{d}$ from cooling-water well N8068 (fig. 5). This discharge has relatively low VOC concentrations (far below New York State Health Department drinking-water guidelines for VOCs) and is not discussed further herein.

\section{Ground-Water Movement}

The regional direction of ground-water movement in this area is southwest from the mid-island ground-water divide ( $f i g .1$ ), about $2 \mathrm{mi}$ north of Roosevelt Field, to discharge areas at and beyond the south shore in southeastern Queens County and southwestern Nassau County (Donaldson and Koszalka, 1983a, b, c). The water table in this area is in the upper glacial aquifer and lies 25 to 50 $\mathrm{ft}$ below land surface. Confined conditions predominate in deeper zones of the Magothy aquifer, where silty and clayey layers form local confining units (Franke and McClymonds, 1972). Flow in this system is predominantly horizontal because the bedding planes are almost horizontal and thus provide less resistance to lateral flow, and because the clayey layers retard vertical flow. The potentiometric surface of deeper aquifer zones at Roosevelt Field is lower than the water table; thus, ground-water movement in this area has a downward component.

Water levels in wells screened in the upper glacial aquifer were measured at least twice yearly during 1982-84. The first measurements each year were made in the spring before the start of cooling-water pumping to delineate flow patterns during periods of near-minimal pumping. Measurements were again made in August, during periods of peak withdrawals for cooling water and public supply, to evaluate the changes induced by pumping stresses, which are primarily in the Magothy aquifer, and by the cooling-water discharges.

\section{Upper Glacial Aquifer}

Plate 1 shows the water-table configuration drawn from 61 measurements made on April 25, 1984. April 1984 was a period of minimal ground-water pumping and discharge at Roosevelt Field, and regional flow was southsouthwestward (S25 $\mathrm{W}$ ) and primarily horizontal. The average water-table gradient was $0.0012 \mathrm{ft} / \mathrm{ft}$. The rate of regional horizontal ground-water flow in the upper glacial aquifer during low-stress periods, based on a hydraulic conductivity of $250 \mathrm{ft} / \mathrm{d}$ and a porosity of 0.30 (McClymonds and Franke, 1972), is about $1.0 \mathrm{ft} / \mathrm{d}$. 
Stormwater runoff and discharged cooling water that enter Pembrook recharge basin cause a water-table mound 1 to $2 \mathrm{ft}$ high that persists throughout the year. This mound was 2 to $4 \mathrm{ft}$ high, however, during warm weather, when up to $4 \mathrm{Mgal} / \mathrm{d}$ of spent cooling water is discharged to the basin, as seen in the August 1982-84 water-table maps (figs. 7A, 7B, and 7C).

August 1982 water table.--The water-table map in figure 7A was drawn from 34 measurements made on August 19, 1982. The water-table mounding beneath Pembrook recharge basin was 2 to $3 \mathrm{ft}$ above the regional water table in the

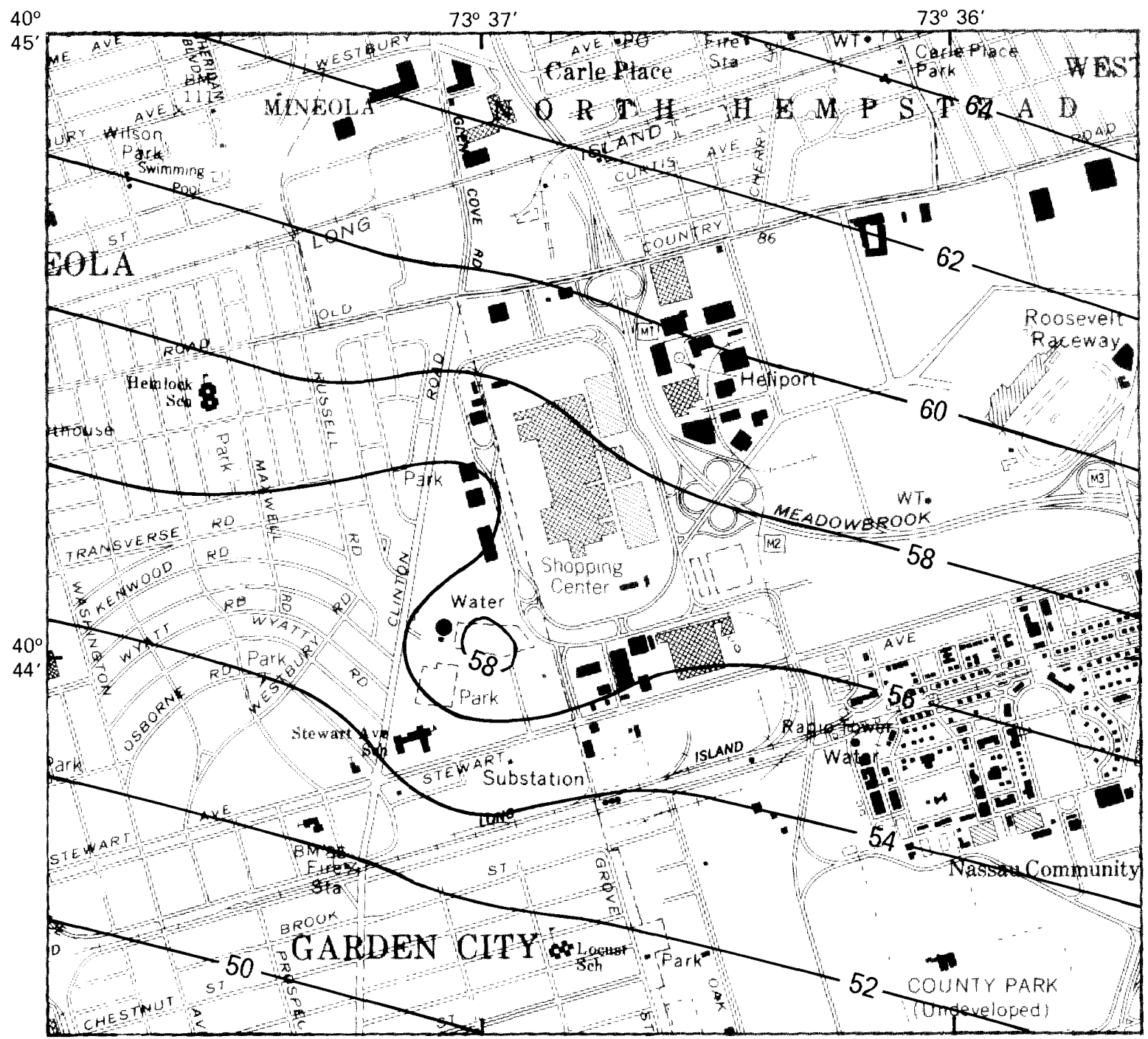

Base from NYSDOT, Freeport, NY, 1981; Lynbrook, NY, 1981;

Sea Cliff, NY, 1981; and Hicksville, NY, 1981, 1:24,000

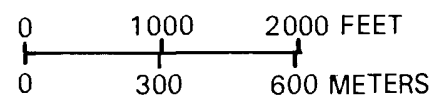

EXPLANATION

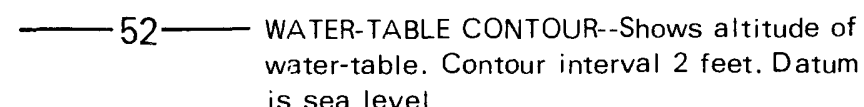
is sea level

Figure 7A.--Water-table configuration at Roosevelt Field in August 1982. (Location is shown in fig. 1.) 
area. Spent cooling water (about $4 \mathrm{Mgal} / \mathrm{d}$ ) from six wells at Roosevelt Field (N5507, N6045, N8050, N8458, N9310, and N9311, p1. 1) caused overflow into Nassau County basin 124, which eventually infiltrated the basin floor or evaporated.

A slight depression of 1 to $2 \mathrm{ft}$ in the water table is indicated about $1,200 \mathrm{ft}$ north of Pembrook recharge basin (fig. 7A). This is attributed to withdrawal from the Magothy aquifer at wells N9310 and N9311, at the west side of the shopping mall, which are screened 180 to $230 \mathrm{ft}$ below land surface.

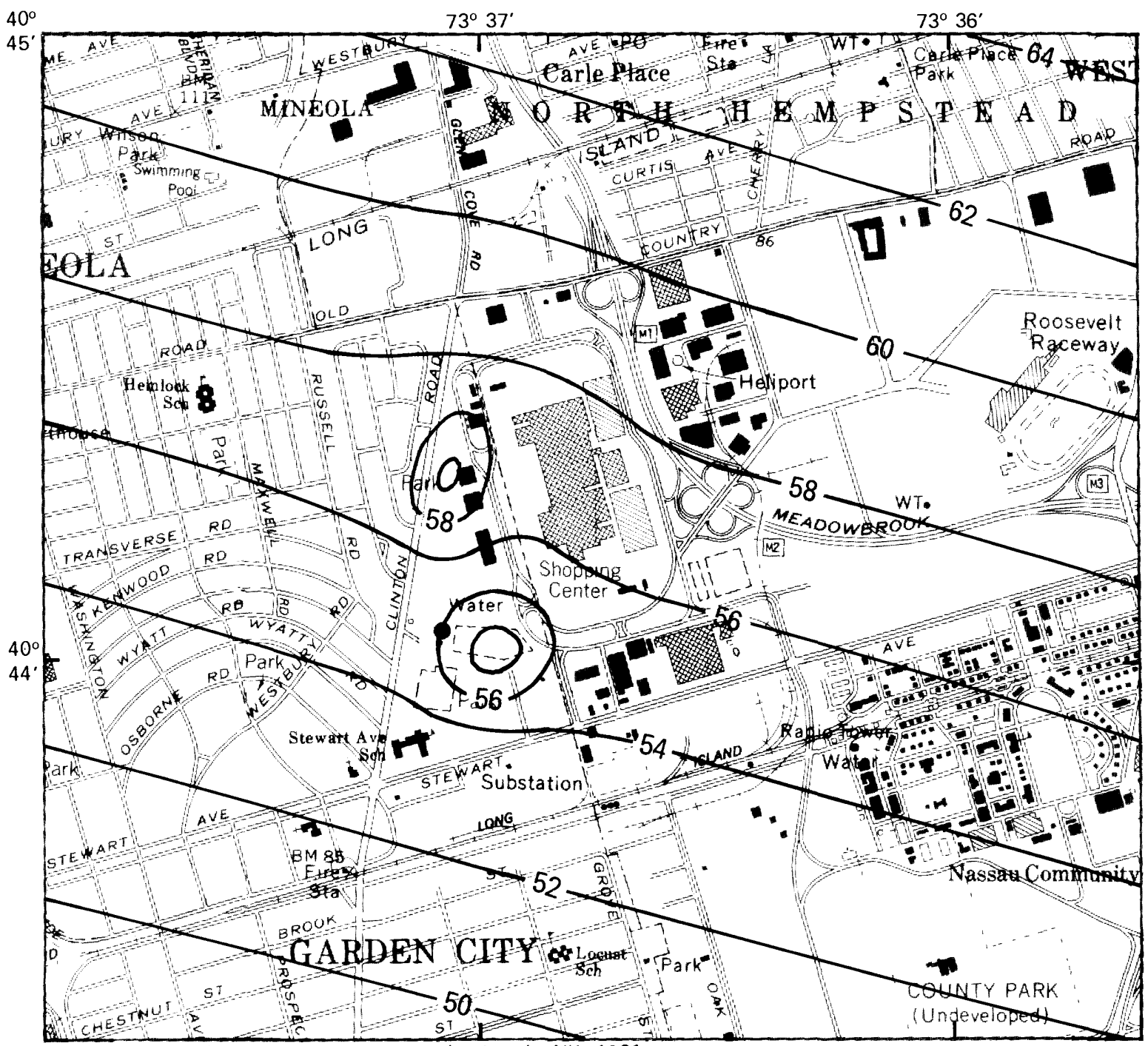

Base from NYSDOT, Freeport, NY, 1981; Lynbrook, NY, 1981;

Sea Cliff, NY, 1981; and Hicksville, NY, 1981, 1:24,000

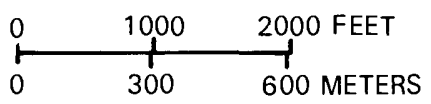

EXPLANATION

- $52-$ WATER-TABLE CONTOUR--Shows altitude of water-table. Contour interval 2 feet. Datum is sea level

Figure 7B.--Water-table configuration at Roosevelt Field in August 1983. (Location is shown in fig. 1.) 
Pumpage from these two wells during warm weather is about $1.2 \mathrm{Mgal} / \mathrm{d}$. This is the shallowest withdrawal at Roosevelt Field, and the good hydraulic connection between the upper zone of the Magothy aquifer and the water-table aquifer in this area causes a slight water-table depression. A local reversal in water-table gradient between the depressed area and the mound beneath Pembrook recharge basin was created during the summer of 1982 (fig. 7A). The seasonal flow of ground water from the area of Pembrook recharge basin toward the depressed area against the regional hydraulic gradient is indicated by hydrographs for wells N9955 and N9958 (fig. 8).

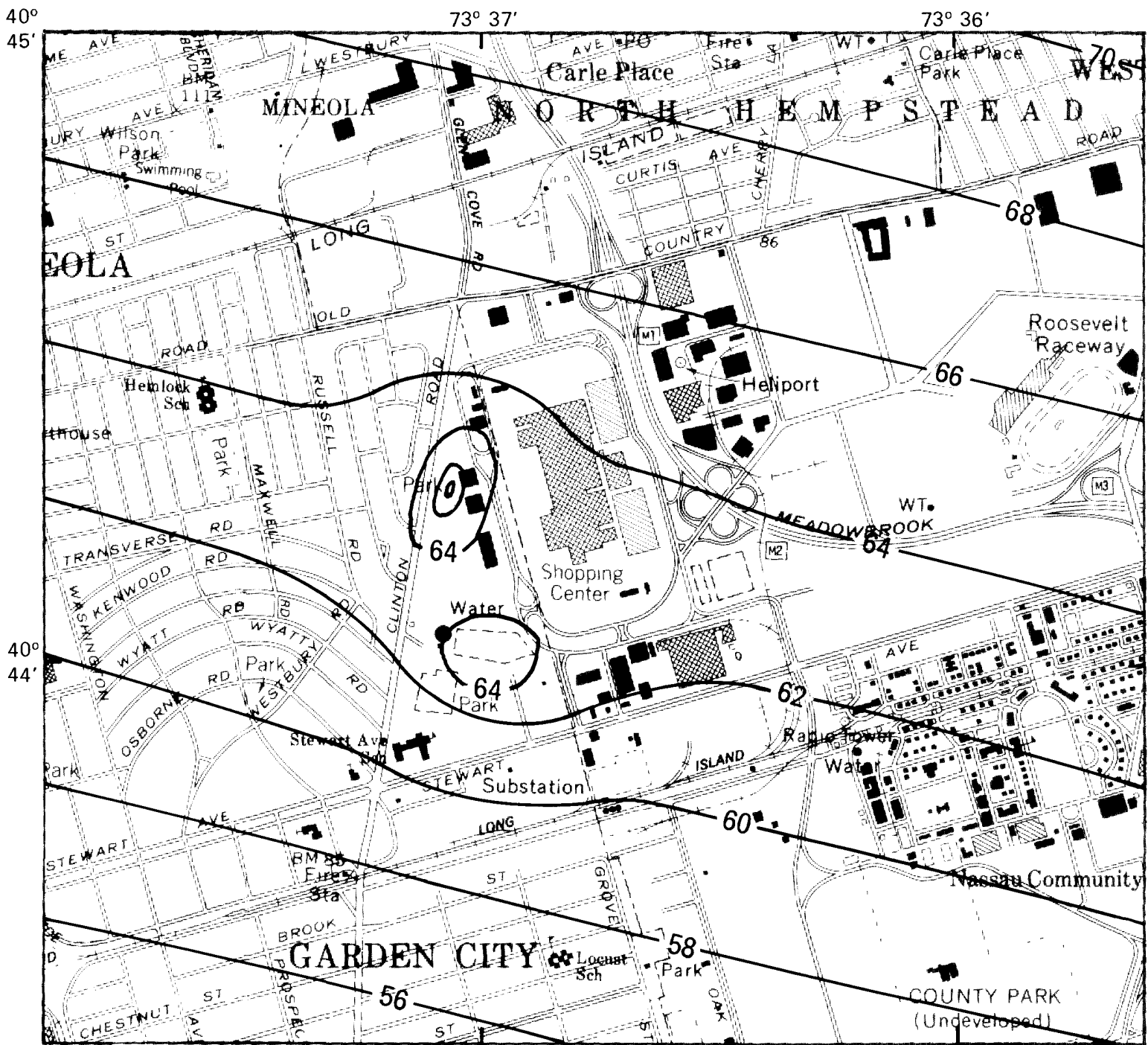

Base from NYSDOT, Freeport, NY, 1981; Lynbrook, NY, 1981;

Sea Cliff, NY, 1981; and Hicksville, NY, 1981;1:24,000

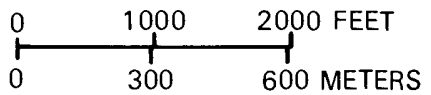

EXPLANATION

- $62-$ WATER-TABLE CONTOUR--Shows altitude of water-table. Contour interval 2 feet. Datum is sea level

Figure 7C.--Water-table configuration at Roosevelt Field in August 1984. (Location is shown in fig. 1.) 


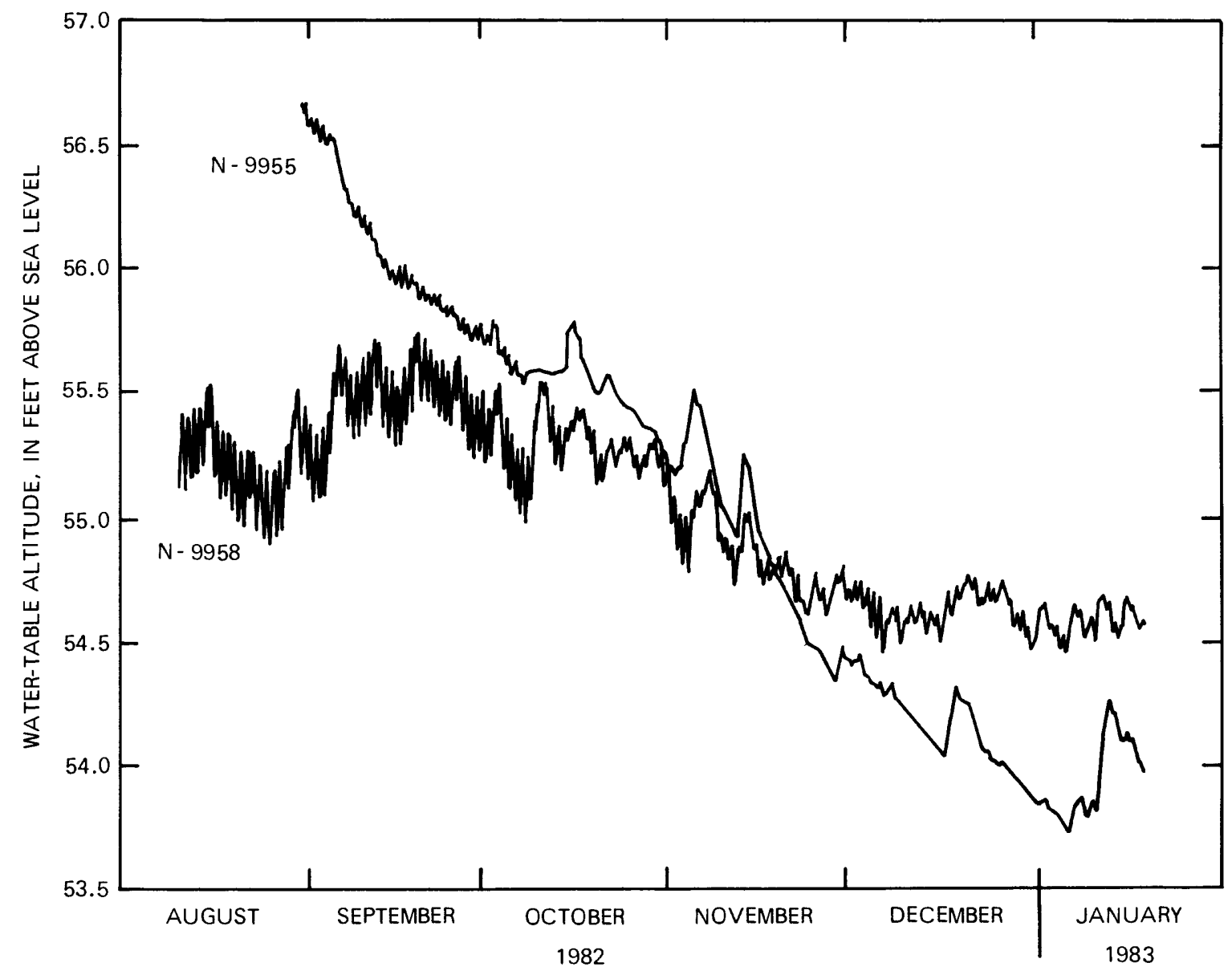

Figure 8.--Water-table altitudes at wells $N 9955$ near Pembrook recharge basin and N9958 near Garden City Plaza from August 1982 through January 1989. Higher levels in well $N 9955$ from August through October reflect the discharge of water at nearby Pembrook recharge basin, and lower levels in well N9958 reflect pumping at nearby Magothy wells $N 9910$ and N9811. Effects of pumping and discharge dissipate after October, and the regional water-table gradient again dominates.

August 1983 water table.--The 1983 water-table map (fig. 7B) was drawn from 52 measurements made on August 31, 1983. The mound beneath Pembrook recharge basin was 3 to $4 \mathrm{ft}$ above the regional water table. At this time, cooling water from wells $\mathrm{N} 9310$ and $\mathrm{N} 9311$ was diverted to the new drain field $1,400 \mathrm{ft}$ north of the recharge basin (fig. 5) rather than to Pembrook recharge basin to alleviate overflow from the basin into Nassau County basin 124 . This discharge to the drain field created a new water-table mound 3 to $4 \mathrm{ft}$ high, which was elongated along Clinton Road (fig. 7B). This mound replaced the water-table depression observed in 1982 ( $\mathrm{fig}$. 7A).

August 1984 water table.--The 1984 water-table map (fig. 7C) was drawn from 38 measurements made on August 8, 1984. Two mounds are evident, as in August 1983 (fig. 7B). The mound beneath Pembrook recharge basin was 2 to 3 $\mathrm{ft}$ above the regional level, and the one beneath the drain field was 4 to $5 \mathrm{ft}$ 
above the regional level. A small decrease in the height of the mound beneath the basin and an increase in the mound height beneath the drain field from August 1983 (fig. 7B) to August 1984 (fig. 7C) probably resulted from the diversion of discharge water from wells N9310 and N9311 from the basin after initial operation of the drain field in August 1983. In 1984, all water (2.1 Mgal/d) from these wells was discharged to the drain field.

\section{Magothy Aquifer}

The potentiometric surface of the Magothy aquifer was measured in conjunction with water-table measurements in April 1982-84, when most pumping wells had been idle for at least 48 hours. The horizontal hydraulic gradient in April 1984 was about $0.0013 \mathrm{ft} / \mathrm{ft}$, and flow was generally west-southwestward. The potentiometric-surface configuration of the Magothy aquifer is similar to that of the water table in the upper glacial aquifer when pumps are off, but heads in the Magothy aquifer are generally 1 to $2 \mathrm{ft}$ lower than the water table, and flow is slightly more westward. The rate of horizontal flow at Roosevelt Field, based on a hydraulic conductivity of $56 \mathrm{ft} / \mathrm{d}$ and effective porosity of 0.30 (McClymonds and Franke, 1972), averages about $0.3 \mathrm{ft} / \mathrm{d}$, but rates may range from negligible to $0.6 \mathrm{ft} / \mathrm{d}$. This average flow rate represents only nonpumping conditions, however.

The potentiometric-surface altitude during periods of sumer pumping could not be determined because most wells used for measurement were being pumped. The surface is apparently uneven because localized depressions that may exceed $50 \mathrm{ft}$ in depth develop and recover in response to variable pumping schedules for cooling water and public supply. Water-level measurements at wells about $1,000 \mathrm{ft}$ from several pumping centers in the Magothy aquifer indicated that heads there were 2 to $4 \mathrm{ft}$ lower than the water table during warm-weather pumping.

\section{Downward Movement of Water in the Aquifer System}

Hydraulic-head measurements in clusters of wells having screens set at different depths were used to evaluate daily and seasonal fluctuations in vertical hydraulic gradient, which reflect pumping and recharge and also the hydraulic conductivity between screened zones. Ground water has a downward flow component beneath all of Roosevelt Field. The downward component results from hydraulic heads in the middle and basal sections of the Magothy aquifer that are lower than hydraulic heads in the upper glacial aquifer. The vertical hydraulic gradient generally increases considerably during warm weather, when heads in the Magothy aquifer are lowered by cooling-water and public-supply withdrawals and when mounds of discharge water in the upper glacial aquifer are highest. Thus, the rates of vertical ground-water movement are greatest during summer periods of peak water demand and cooling-water discharge.

The influence of withdrawals from the Magothy aquifer on vertical gradients during warm weather at Roosevelt Field is illustrated in hydrographs (fig. 9) for wells N9955 and N10020, near the southwest corner of the shopping center. Well $\mathrm{N} 9955$ is screened in the upper glacial aquifer, $35 \mathrm{ft}$ above sea level; well N10020 is screened in the upper part of the Magothy aquifer, 107 
ft below sea level. The 1982 hydrographs (left side of fig. 9) represent September 7 to October 5, a period of warm weather. Combined public-supply and cooling-water pumpage from the Magothy aquifer within 1,500 ft of the well cluster was about $6.5 \mathrm{Mgal} / \mathrm{d}$. During this period, the water table in the upper glacial aquifer (N9955) gradually declined but had daily fluctuations of about $0.1 \mathrm{ft}$ due in part to recharge at the nearby Pembrook recharge basin. In contrast, The potentiometric surface in the Magothy aquifer (N10020) during this period fluctuated nearly $3.0 \mathrm{ft}$ dally. The maximum vertical hydraulic gradient between screened zones at these two wells during this period was $0.032 \mathrm{ft} / \mathrm{ft}$ on September 13. The minimum gradient, when pumps were off, was $0.008 \mathrm{ft} / \mathrm{ft}$ on September 18 .

The influence of public-supply withdrawals from the Magothy aquifer on vertical gradients at Roosevelt Field during cool weather is seen in the hydrographs on the right side of figure 9, which depicts water levels from February 18 through March 20, 1983. The only pumping in the area at that time was public-supply withdrawal of about $1 \mathrm{Mgal} / \mathrm{d}$ at two wells (N3934 and N3935), $900 \mathrm{ft}$ west of $\mathrm{N} 9955$ and $\mathrm{N} 10020$. The water-table altitude generally increased during this time, and no daily fluctuations are apparent, although recharge from several storms is evident. In contrast, the potentiometric surface in the Magothy aquifer fluctuated by about $1 \mathrm{ft}$ daily in response to the

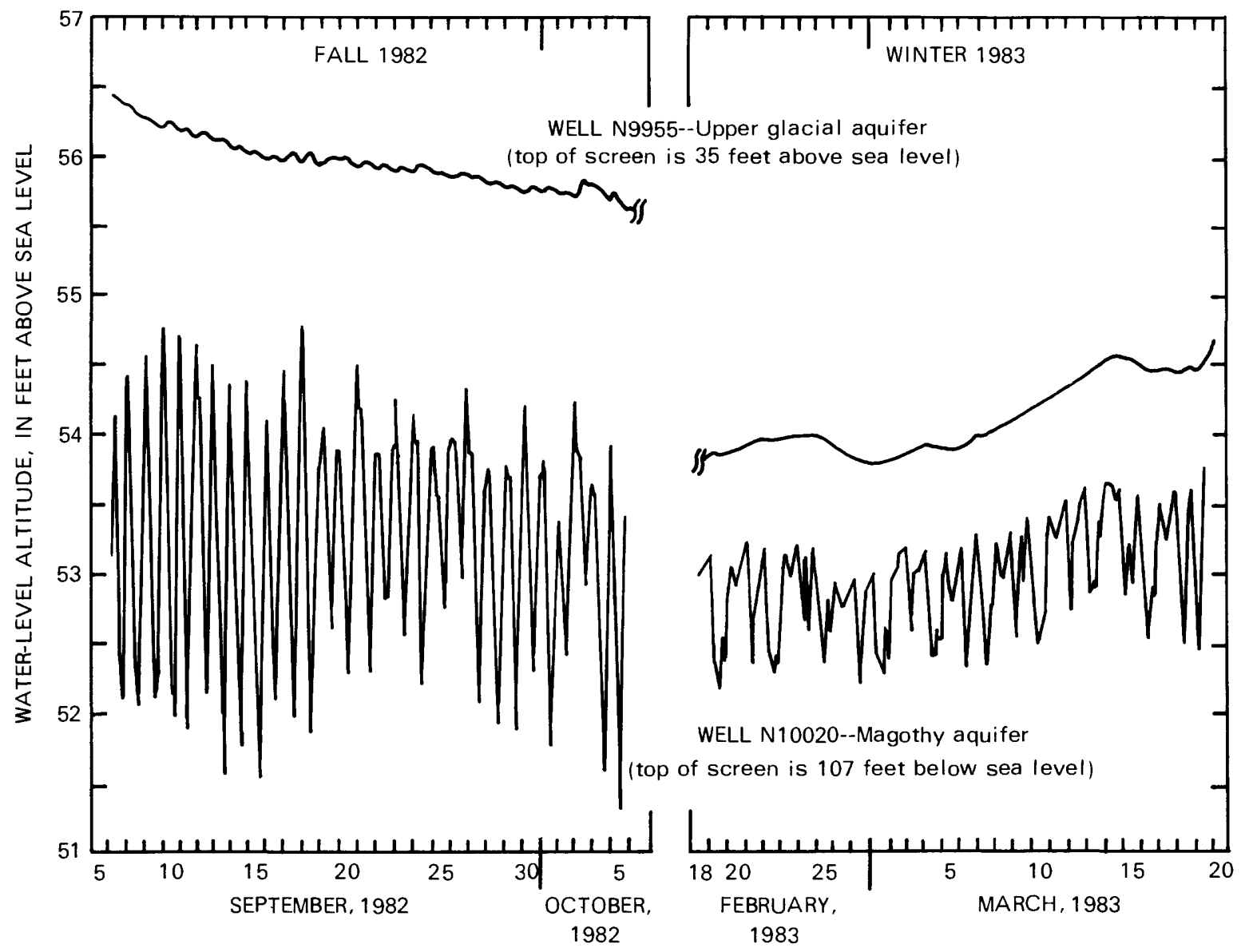

Figure 9.--Water-level fluctuations at wells $N 9955$ and N10020, near southwest corner of shopping center: Left, during a month of warm weather in fall 1982. Right, during a month of cool weather in winter 1983. (Well locations are shown on $p l .1$. 
public-supply pumping. The maximum vertical hydraulic gradient between screened zones of the two wells during this period was $0.014 \mathrm{ft} / \mathrm{ft}$ on March 19 , and the minimum observed gradient was $0.004 \mathrm{ft} / \mathrm{ft}$ when pumps were off on March 2. In general, the mean vertical gradient during the cool-weather period was about half that during the warm-weather period. Accordingly, average vertical flow rates in March 1983 at this well site were about half the average vertical flow rate in September 1982.

\section{Inorganic Chemical Constituents in Ground Water}

Inorganic chemical constituents and physical characteristics were measured in 183 samples from 105 wells screened in the upper glacial and Magothy aquifers; the results are summarized in table 3 . Dissolved oxygen (DO), which indicates oxidizing conditions, was detected at most wells, and specific conductance values were generally low, ranging from 33 to $850 \mu \mathrm{S} / \mathrm{cm}$ (microsiemens per centimeter at $25^{\circ} \mathrm{C}$ ). The median specific conductance in the upper glacial aquifer was $250 \mu \mathrm{S} / \mathrm{cm}$ and in the Magothy aquifer was $97 \mu \mathrm{S} / \mathrm{cm}$. Median $\mathrm{pH}$ in the upper glacial aquifer was 6.2 and in the Magothy aquifer was 5.8. The median alkalinity in the upper glacial aquifer was $20 \mathrm{mg} / \mathrm{L}$ (as $\mathrm{CaCO}_{3}$ ) and in the Magothy aquifer was $6 \mathrm{mg} / \mathrm{L}$. In general, median concentrations of inorganic chemical constituents were consistently lower in the Magothy aquifer than in the upper glacial aquifer (table 3), except silica.

Water from the Magothy aquifer generally has lower concentrations of inorganic chemical constituents than water from the upper glacial aquifer, presumably because water from the Magothy aquifer is older and reflects the less urbanized conditions of the past. Dilution and dispersion in the Magothy aquifer also reduce concentrations of constituents that originated at land surface and moved through the upper glacial aquifer. The differences in median concentrations of inorganic chemical constituents between the two aquifers are small, however, and the discharge of cooling water pumped from the Magothy aquifer does not significantly alter the concentrations of constituents in the upper glacial aquifer.

Dissolved iron and manganese and total nitrate concentrations were the only inorganic chemical constituents that exceeded New York State drinkingwater standards. Dissolved iron concentrations exceeded drinking-water standards in 40 percent of the wells sampled, and manganese concentrations exceeded the standards in 27 percent, probably because of localized reducing environments. The median nitrate concentration was $3.8 \mathrm{mg} / \mathrm{L}$ (as $\mathrm{N}$ ) in the upper glacial aquifer and $3.6 \mathrm{mg} / \mathrm{L}$ in the Magothy aquifer, but the difference was not statistically significant ( $\alpha$ equals 0.05 ). Elevated nitrate concentrations in the Magothy aquifer may have originated from agricultural fertilizers and septic-waste disposal before ex-tensive development of the area, whereas nitrate in the upper glacial aquifer may have originated from more recent sources such as lawn fertilization in medium- to high-density suburban areas (Katz and Iindner, 1978). Nitrate exceeded drinking-water standards in 6 percent of all wells sampled. Public-supply we11s N2747, N5654, and N6046 (not sampled), which tap the Magothy aquifer in the Roosevelt Field area, have had excessive nitrate concentrations and as a result are unused. 
Table 9.--Summary of inorganic chemical analyses of ground water from wells in the Roosevelt Field area of Nassau County, 1984

[A11 concentrations are in milligrams per liter]

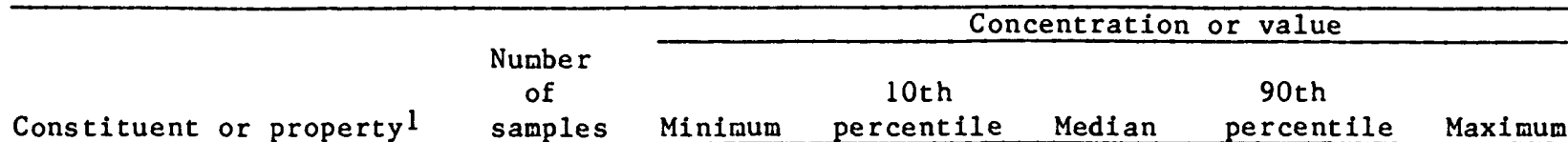

A. Wells screened in upper glacial aquifer

\begin{tabular}{|c|c|c|c|c|c|c|}
\hline $\begin{array}{l}\text { Total dissolved solids } \\
\text { Specific conductance } \\
\left(\mu \mathrm{S} / \mathrm{cm} \text { at } 25^{\circ} \mathrm{C}\right)\end{array}$ & $\begin{array}{l}53 \\
53\end{array}$ & $\begin{array}{l}64 . \\
92 .\end{array}$ & $\begin{array}{r}79 . \\
130 .\end{array}$ & $\begin{array}{l}171 \\
250 .\end{array}$ & $\begin{array}{l}335 . \\
423 .\end{array}$ & $\begin{array}{l}487 \\
850\end{array}$ \\
\hline $\mathrm{pH}$ & 53 & 4.4 & 5.5 & 6.2 & 6.6 & 6.8 \\
\hline Alkalinity $\left(\right.$ as $\left.\mathrm{CaCO}_{3}\right)$ & 52 & 1. & 5. & 20. & 37. & 65. \\
\hline Nitrite $\left(\mathrm{NO}_{2}\right.$ as $\left.\mathrm{N}\right)$ & 53 & $<.001$ & .002 & .008 & .041 & .481 \\
\hline Nitrate $\left(\mathrm{NO}_{3}\right.$ as $\left.\mathrm{N}\right)$ & 52 & $<.10$ & .63 & 3.8 & 7.8 & 15. \\
\hline Total hardness (as $\mathrm{CaCO}_{3}$ ) & 53 & 12. & 24. & 66. & 330. & 650 \\
\hline Calcium (Ca) & 53 & 2.9 & 5.0 & 14. & 35. & 41. \\
\hline Magnesium (Mg) & 53 & 1.1 & 1.6 & 3.5 & 9.7 & 18. \\
\hline Sodium ( $\mathrm{Na}$ ) & 52 & 5.0 & 9.0 & 22. & 49. & 130 \\
\hline Potassium (K) & 53 & .3 & .9 & 2.4 & 5.1 & 8.4 \\
\hline Chloride ( $\mathrm{Cl})$ & 53 & 7.5 & 13. & 39. & 78. & 246 . \\
\hline Fluoride (F) & 53 & $<.2$ & $<.2$ & $<.2$ & $<.2$ & 0.2 \\
\hline Sulfate $\left(\mathrm{SO}_{4}\right)$ & 52 & $<5$. & $<5$. & 24. & 72. & 81 . \\
\hline Iron $(\mathrm{Fe})$ & 53 & $<.05$ & $<.05$ & .43 & 5.3 & 9.3 \\
\hline Manganese $(\mathrm{Mn})$ & 53 & $<.05$ & $<.05$ & $<.05$ & .83 & 2.8 \\
\hline Silica $\left(\mathrm{SiO}_{2}\right)$ & 53 & 1.3 & 3.1 & 5.7 & 8.1 & 8.6 \\
\hline
\end{tabular}

B. Wells screened in Magothy aquifer

Total dissolved solids

Specific conductance $\left(\mu \mathrm{S} / \mathrm{cm}\right.$ at $\left.25^{\circ} \mathrm{C}\right)$

$\mathrm{pH}$

Alkalinity (as $\mathrm{CaCO}_{3}$ )

Nitrite $\left(\mathrm{NO}_{2}\right.$ as $\left.\mathrm{N}\right)$

Nitrate $\left(\mathrm{NO}_{3}\right.$ as $\left.\mathrm{N}\right)$

Total hardness (as $\mathrm{CaCO}_{3}$ )

Calcium ( $\mathrm{Ca}$ )

Magnesium ( $\mathrm{Mg}$ )

Sodium ( $\mathrm{Na}$ )

Potassium (K)

Chloride (C1)

Fluoride (F)

Sulfate $\left(\mathrm{SO}_{4}\right)$

Iron ( $\mathrm{Fe}$ )

Manganese $(M n)$

Silica $\left(\mathrm{SiO}_{2}\right)$

\begin{tabular}{|c|c|c|c|c|c|}
\hline $\begin{array}{l}54 \\
54\end{array}$ & $\begin{array}{l}29 . \\
33 .\end{array}$ & $\begin{array}{l}36 . \\
46 .\end{array}$ & $\begin{array}{l}64 . \\
97 .\end{array}$ & $\begin{array}{l}188 . \\
334 .\end{array}$ & $\begin{array}{l}302 . \\
533 .\end{array}$ \\
\hline 54 & 4.9 & 5.3 & 5.8 & 6.2 & 7.0 \\
\hline 54 & 1. & 2. & 6. & 12. & 25. \\
\hline 54 & $<.001$ & $<.001$ & .002 & .015 & .030 \\
\hline 54 & $<.10$ & .55 & 3.6 & 9.6 & 13. \\
\hline 54 & 7 & 9.5 & 22 & 67. & 111. \\
\hline 54 & 1.3 & 2.2 & 5.5 & 17. & 27 . \\
\hline 54 & .4 & .5 & 2.4 & 5.0 & 10 \\
\hline 54 & $<3$ & 3.0 & 8.0 & 28. & 85. \\
\hline 54 & .2 & .5 & .9 & 1.8 & 5.7 \\
\hline 54 & 3.5 & 5.4 & 11. & 51. & 166. \\
\hline 54 & $<.02$ & $<.2$ & $<.2$ & $<.2$ & $<.2$ \\
\hline 54 & $<5$. & $<5$. & 6. & 26 . & 77. \\
\hline 42 & $<.05$ & $<.05$ & $<.05$ & .88 & 5.2 \\
\hline 42 & $<.05$ & $<.05$ & $<.05$ & .07 & .40 \\
\hline 54 & 4.4 & 5.4 & 6.9 & 9.4 & 14 \\
\hline
\end{tabular}

1 All constituents are total concentrations from unfiltered samples, except for iron and manganese, which are dissolved concentrations from filtered ( $0.45-\mu m$ membrane) samples. 


\section{Ground-Water Temperature}

The median ground-water temperature at wells in the Roosevelt Field area, excluding those affected by cooling-water discharge, was $11^{\circ} \mathrm{C}$; the range was from $10^{\circ} \mathrm{C}$ to $15^{\circ} \mathrm{C}$. Ground-water temperature fluctuated strongly with season in wells adjacent to the Pembrook recharge basin. In well N10097, near the basin, water temperature ranged from $7.3^{\circ} \mathrm{C}$ (May 1984) to $22.6^{\circ} \mathrm{C}$ (September 1984), reflecting cold storm-runoff water during the winter and water warmed by air conditioning in the summer. Ground-water temperature at other wells near the basin, N9966 and N10096, indicated similar seasonal effects in response to the discharge of cooling water.

\section{VOLATILE ORGANIC COMPOUNDS IN GROUND WATER}

\section{Chemical Character}

Volatile or purgeable organic compounds generally are defined as lowmolecular-weight hydrocarbons having less than 2-percent solubility in water and boiling points below $150^{\circ} \mathrm{C}$. Most are liquid at room temperature. Some common priority pollutants (U.S. Environmental Protection Agency, 1979b) include vinyl chloride, trichloroethylene, tetrachloroethylene, chloroform, carbon tetrachloride, benzene, toluene, and chlorobenzene. Each is considered toxic to some degree, and most, including TCE, are believed to be carcinogenic (National Academy of Sciences, 1977). The U.S. Environmental Protection Agency $(1979 \mathrm{~b}, \mathrm{c})$ has described and assessed TCE and other VOC's in the environment and discussed their transport and fate in ground water.

The physical properties of TCE are typical of chlorlnated aliphatic VOC's. It is a colorless liquid with a density of $1.46 \mathrm{~g} / \mathrm{mL}$ (grams per milliliter) at $20^{\circ} \mathrm{C}$. It has a molecular weight of 131 , a boiling point of $87^{\circ} \mathrm{C}$, and a solubility in water of $1,100 \mathrm{mg} / \mathrm{L}$ (about $1 / 10$ percent by weight). The structural configuration of TCE is:<smiles>ClC=C(Cl)Cl</smiles>

The compounds listed above are used primarily as solvents. Typical sources of these compounds include dry-cleaning fluids, degreasing solvents, organic drain cleaners, furniture-refinishing compounds, and gasoline or other fuels. TCE has been in commercial use less than 40 years. The New York State Health Department guidelines in 1984 for maximum concentrations in drinking water were $5 \mu \mathrm{g} / \mathrm{L}$ for vinyl chloride and benzene, $50 \mu \mathrm{g} / \mathrm{L}$ for each of the remaining VOC's, including TCE, and $100 \mu \mathrm{g} / \mathrm{L}$ for total VOC concentration.

The solubilities of VOC's in ground water are very low, and the loss of VOC's from solution to clean air occurs readily. Conversely, clean water exposed to air containing a volatile organic compound in gaseous form can rapidly accumulate detectable levels of the compound in solution, and falsepositive tests resulting from this phenomenon are common in analytical laboratories where solvents are frequently used. Thus, extensive precautions 
must be taken in collection and storage of ground-water samples intended for VOC analysis. Exposure to air must be minimized during sample collection, and sample bottles must be filled to the top and sealed to eliminate exposure to gas phases and are chilled for storage. They have a finite shelf life.

\section{Concentrations at Roosevelt Field}

The principal VOC in ground water at Roosevelt Field is trichloroethylene (TCE); cis-1,2-dichloroethylene (DCE) and tetrachloro-ethylene (PCE) occur in lesser concentrations. (See tables 7 and 8 , at end of report.) Trichloroethylene was found in 44 percent of the wells sampled throughout the Roosevelt Field area in 1984, and the maximum concentration was $38,000 \mu \mathrm{g} / \mathrm{L}$. Tetrachloroethylene was detected in 46 percent of the wells sampled, and the maximum concentration was $350 \mu \mathrm{g} / \mathrm{L}$. cis-1,2-Dichloroethylene was detected in 21 percent of the wells sampled, the maximum concentration was $2,800 \mu \mathrm{g} / \mathrm{L}$. TCE, DCE, and tetrachloroethylene were detected in August 1984 in the combined outflow from three cooling-water wells that tap the Magothy aquifer (N5507, N8050, and N8458); this water was discharged after use to Pembrook recharge basin. TCE, DCE, and minor amounts of tetrachloroethylene were also detected in the combined outflow from the two cooling-water wells (N9310 and N9311) that discharge water after use to the Garden City Plaza drain field.

Forty water samples from 28 public-supply wells were also collected in 1983 and 1984 (table 8). VOC's were detected in 9 wells, 4 of which contained more than $25 \mu \mathrm{g} / \mathrm{L}$ total VOC's. Ground-water samples from public-supply wells N3934 and N3935 (owned by the Village of Garden City) and N5484 and N5485 (owned by the Town of Hempstead) in April 1984 contained 22, 27, 13, and 26 $\mu_{8} / L$, respectively, of total VOC's, principally TCE. A sample from well N83 (owned by the Village of Hempstead) in April 1984 contained $29 \mu \mathrm{g} / \mathrm{L}$ of TCE and $15 \mu \mathrm{g} / \mathrm{L}$ of tetrachloroethylene. All samples from public-supply wells met New York State Health Department drinking-water guidelines of $50 \mu \mathrm{g} / \mathrm{L}$ for individual VOC's.

VOC concentrations in excess of drinking-water guidelines have been detected in several monitoring wells not associated with the TCE at Roosevelt Field. Samples obtained in spring 1984 from wells N1160, N9703, and N9803 southeast of Roosevelt Field (p1. 2) contained $53 \mu \mathrm{g} / \mathrm{L}$ of 1,1,1-trichloroethane, $260 \mu \mathrm{g} / \mathrm{L}$ of cis-1,2-dichloroethylene, and $280 \mu \mathrm{g} / \mathrm{L}$ of 1,1,1-trichloroethane, respectively. Gasoline was detected in water from well N9951 at the northwest corner of Roosevelt Field in August 1983, but in April 1984, after the well screen was raised $10 \mathrm{ft}$ to a shallower zone in the upper glacial aquifer, none was detected. In addition, trace amounts of chloroform, carbon tetrachloride, and other volatile compounds were detected as isolated occurrences throughout the study area.

\section{Trichloroethylene (TCE), 1,2-Dichloroethylene, and Tetrachloroethylene in Discharged Cooling Water}

Of seven cooling-water wells at Roosevelt Field, five yield contaminated water from the Magothy aquifer, which is discharged after use to the upper glacial aquifer at the Garden City Plaza drain field and the Pembrook recharge basin (fig. 5). Water from wells $\mathrm{N} 9310$ and N9311 at Garden City Plaza has 
created a plume of TCE and DCE at the drain field; the contaminants had reached monitoring wells N8666, N9953, N9954, N9964, N9971, N9972, N9973, N9974, and N10095 (p1. 1) by 1984. At Pembrook recharge basin, water discharged from nearby cooling-water wells N5507, N8050, and N8458 created a plume of TCE, DCE, and tetrachloroethylene that had reached wells N9954, N9955, N9965, N9966, N10096, N10035, N10097, N10204, and N10205 by 1984. These two plumes of contaminated discharge water overlie and partly obscure the original plume of VOC's in the upper glacial aquifer.

\section{Discharge to Pembrook Recharge Basin}

Samples for VOC analysis were collected, and discharge rates measured, on August 7, 1984, at (1) the four cooling-water wells that discharged to Pembrook recharge basin, (2) the basin's inflow and outflow culverts and midpoint, and (3) three monitoring wells around the basin. The same was done the next day at (1) the two cooling-water wells that discharged to the Garden City Plaza drain field, (2) the inflow and outflow of the aeration facility, and (3) four monitoring wells near the drain field. Discharges of TCE, DCE, and tetrachloroethylene at each point were computed by multiplying flow rate by the concentration and converting the units to pounds of VOC per day, assuming an average 12-hour pumping and discharge duration. The data are presented in table 4. The values for each well represent the rate of withdrawal of each contaminant from the Magothy aquifer; the values for the recharge basin and drain field represent the rate of return to the upper glacial aquifer.

About $19 \mathrm{lb} / \mathrm{d}$ of TCE and $2.7 \mathrm{lb} / \mathrm{d}$ of tetrachloroethylene were removed from the Magothy aquifer by pumping at wells N5507, N8050, and N8458, on the assumption that flow rate and concentrations were constant (table 4). About $13 \mathrm{lb} / \mathrm{d}$ of TCE (principally from well N8050) and $3.2 \mathrm{lb} / \mathrm{d}$ of tetrachloroethylene (principally from well N5507) were discharged to Pembrook recharge basin. About $500 \mathrm{gal} / \mathrm{min}$ of public-supply water augmented the cooling-water supply and diluted the discharge. Flow rates and water-quality samples collected at the midpoint of Pembrook basin, where a berm separates the basin into a north and a south section, indicate that the south section has higher infiltration rates than the north section but lower concentrations of TCE. About $2.5 \mathrm{lb} / \mathrm{d}$ of TCE was discharged in the $1,200-\mathrm{gal} / \mathrm{min}$ outflow from Pembrook basin and entered Nassau County basin 124 through a connecting culvert.

Samples from monitoring wells around Pembrook recharge basin directly reflect the quality of water infiltrating the basin. Cooling-water well N5507 and monitoring wells around the basin contained significant concentrations of tetrachloroethylene. This serves as an indicator for distinguishing between water discharged to the recharge basin, other contaminant plumes, and ambient ground water at Roosevelt Field.

\section{Discharge to Garden City Plaza Drain Field}

About $18 \mathrm{lb} / \mathrm{d}$ of TCE and $3 \mathrm{lb} / \mathrm{d}$ of DCE is removed from the Magothy aquifer by pumping at wel1s $\mathrm{N} 9310$ and N9311, near the drain field, assuming constant flow rates and TCE concentrations for the 12-hour pumping day (table 4). The contaminated cooling water is piped in a closed system to the treatment 
facility at 100 Garden City Plaza, where it is aerated and discharged to the nearby drain field. Comparison of TCE concentrations before and after aeration indicated 44-percent removal by the treatment in August 1984; the discharge contained $9.6 \mathrm{lb} / \mathrm{d}$ of TCE and $1.3 \mathrm{lb} / \mathrm{d}$ of DCE. Samples from monitoring wells $\mathrm{N} 9971$, N9972, and $\mathrm{N} 9973$ at the drain field directly reflect the concentrations in the discharge water. The lack of either compound at we11 N9974, $600 \mathrm{ft}$ southeast of the drain field, indicates that this well was beyond the influence of the discharge.

Table 4.--Concentration and discharge of volatile organic compounds in water from six cooling-water wells at Roosevelt Field, August 1984

[Discharge points and well locations are shown in fig. 5; dashes indicate data unavailable]

\begin{tabular}{|c|c|c|c|c|c|c|c|c|}
\hline \multirow[b]{2}{*}{$\begin{array}{r}\text { Discharge } \\
\text { location }\end{array}$} & \multirow{2}{*}{$\begin{array}{l}\text { Screen } \\
\text { setting } \\
\text { (feet } \\
\text { below } \\
\text { land } \\
\text { surface) }\end{array}$} & \multirow[b]{2}{*}{$\begin{array}{c}\text { Flow } \\
\text { rate } \\
(\mathrm{gal} / \mathrm{min})^{a} \\
\end{array}$} & \multicolumn{3}{|c|}{$\begin{array}{c}\text { Concentration } \\
\text { (micrograms per liter) }\end{array}$} & \multicolumn{3}{|c|}{$\begin{array}{c}\text { Discharge } \\
\text { (pounds per day)b }\end{array}$} \\
\hline & & & $\begin{array}{l}\text { 1,2-di- } \\
\text { chloro- } \\
\text { ethylene }\end{array}$ & $\begin{array}{l}\text { tri- } \\
\text { chloro- } \\
\text { ethylene }\end{array}$ & $\begin{array}{l}\text { tetra- } \\
\text { chloro- } \\
\text { ethylene }\end{array}$ & $\begin{array}{l}\text { 1,2-di- } \\
\text { chloro- } \\
\text { ethylene }\end{array}$ & $\begin{array}{l}\text { tri- } \\
\text { chloro- } \\
\text { ethylene }\end{array}$ & $\begin{array}{l}\text { tetra- } \\
\text { chloro- } \\
\text { ethylene }\end{array}$ \\
\hline
\end{tabular}

Contributing wells

A. AT PEMBROOK BASIN

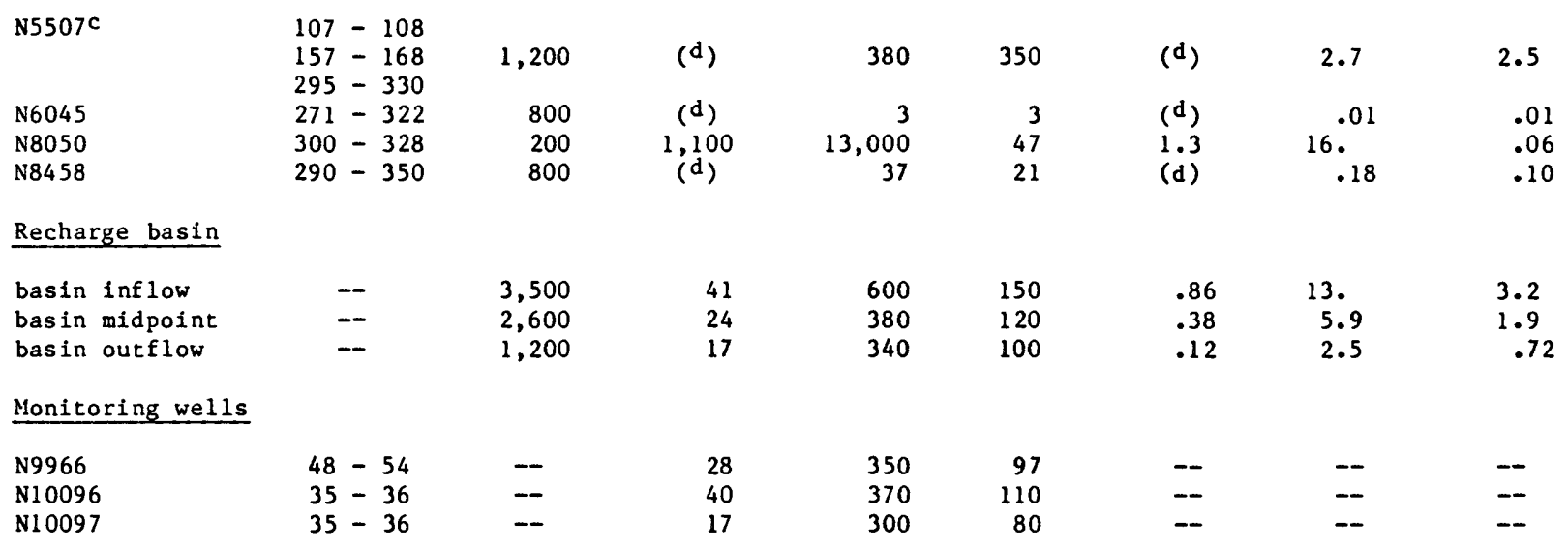

Contributing wells

\begin{tabular}{|c|c|c|c|c|c|c|c|c|}
\hline $\begin{array}{l}\text { N9310 } \\
\text { N9311 }\end{array}$ & $\begin{array}{l}180-230 \\
189-229\end{array}$ & $\begin{array}{l}800 \\
800\end{array}$ & $\begin{array}{r}73 \\
530\end{array}$ & $\begin{array}{r}810 \\
3,000\end{array}$ & $\begin{array}{l}19 \\
10\end{array}$ & $\begin{array}{l}.35 \\
2.5\end{array}$ & 14.9 & $\begin{array}{l}.09 \\
.05\end{array}$ \\
\hline \multicolumn{9}{|l|}{ Drain field } \\
\hline $\begin{array}{l}\text { Untreated inflow } \\
\text { Treated outflow }\end{array}$ & -- & $\begin{array}{l}1,600 \\
1,600\end{array}$ & $\begin{array}{l}270 \\
130\end{array}$ & $\begin{array}{l}1,800 \\
1,000\end{array}$ & $\begin{array}{r}15 \\
3\end{array}$ & $\begin{array}{l}2.6 \\
1.3\end{array}$ & $\begin{array}{l}17 \\
9.6\end{array}$ & $\begin{array}{l}.14 \\
.03\end{array}$ \\
\hline \multicolumn{9}{|l|}{ Monitoring wells } \\
\hline N9971 & $35-40$ & - & 130 & 560 & 3 & -- & -- & -- \\
\hline N9972 & $35-40$ & -- & 100 & 360 & (d) & -- & -- & -- \\
\hline N9973 & $35-40$ & -- & 130 & 550 & 5 & -- & -- & -- \\
\hline N9974 & $30-35$ & -- & (d) & 1 & (d) & -- & -- & -- \\
\hline
\end{tabular}

\footnotetext{
a Gallons per minute.

b Computation of contaminant discharge based on a 12-hour pumping day.

c Well has multiple screens.

d Less than detection limit.
} 


\section{TCE in the Upper Glacial Aquifer}

Three plumes of trichloroethylene contamination have been delineated in the upper glacial aquifer at Roosevelt Field, two of which consist of discharge water overlying the original plume.

\section{Original Plume}

The northernmost (furthest upgradient) extent of the original plume is at wells N8666, N9953, and N9971, as indicated by water-quality samples collected before discharge to the drain field began in 1982; thus, the source of the contamination is probably within or slightly upgradient of the area near the site of aircraft-maintenance hangars when the airfield was closed in 1951 (fig. 2A).

The original plume has moved horizontally downgradient in the upper glacial aquifer and downward into the Magothy aquifer. Its extent is obscured by the overlying plumes of contaminated cooling-water discharge, but historical data from 1981 (table 7, at end of report) indicate that it intersected wells in the upper glaclal aquifer at Garden City Plaza--N8666, N9971, N9972, and N9974--where the drain field is now located. June 1982 data from wells installed after the 1981 sampling, summarized below, indicate that the original plume was also affecting wells N9954 and N9964, southwest and downgradient of Garden City Plaza, and was bounded by wells N9953, N9958, and N9965 on the west and east sides of Garden City Plaza.

\begin{tabular}{lllrr}
\hline & & \multicolumn{3}{c}{ Concentration $(\mu \mathrm{g} / \mathrm{L})$} \\
\cline { 3 - 5 } We11 & Date & DCE & TCE & PCE \\
\hline \multirow{2}{*}{ N8666 } & $3-17-81$ & $<5$ & 120 & 1 \\
N9954 & $6-17-82$ & 30 & 220 & 21 \\
N9964 & $6-18-82$ & $<7$ & 30 & 11 \\
& $6-24-82$ & 16 & 120 & 24 \\
N9971 & $8-13-81$ & $<5$ & 10 & $<1$ \\
N9972 & $8-13-81$ & $<5$ & 15 & $<1$ \\
N9974 & $8-13-81$ & $<5$ & 19 & 9 \\
\hline
\end{tabular}

These data indicate the location of the original plume and its southsouthwestward direction of horizontal movement, parallel to the main direction of regional ground-water flow in the upper glaclal aquifer.

\section{Plume at Garden City Plaza Drain Field}

Since September 1982, the discharge of cooling water originating from wells N9310 and N9311, near the drain field (fig. 5), has contained VOC's in concentration up to $1,000 \mu \mathrm{g} / \mathrm{L}$, even after treatment by aeration. Samples from November 1982 (table 7, at end of report) indicate that initially the contaminated water extended west of the drain fleld and affected well N9953 (210 $\mu_{g} / \mathrm{L}$ of TCE), which had been previously free of VOC's, and we11s N9954 (110 $\mu \mathrm{g} / \mathrm{L}$ TCE) and $\mathrm{N} 9964$ (360 $\mu \mathrm{g} / \mathrm{L} \mathrm{TCE})$, southwest and downgradient of the drain fleld, which had been previously contaminated by the original plume. 
The newly affected wells reflect the extent of radial flow as contaminated discharge water moves away from the seasonal water-table mound created beneath the drain field (fig. 7b, 7c).

Samples from August 1983 and April 1984 indicate that TCE concentrations in the area of the original plume fluctuate in response to the seasonal discharge of cooling water from wells $\mathrm{N} 9310$ and $\mathrm{N} 9311$ and also from dilution by natural recharge. Significant TCE concentrations were detected in August 1983, near the end of the summer cooling season, in wells N9953, N9954, N9964, and N9965, as shown below (data are from table 8, at end of report).

\begin{tabular}{lrrrr}
\hline & & \multicolumn{3}{c}{ Concentration $(\mu \mathrm{g} / \mathrm{L})$} \\
\cline { 3 - 5 } We11 & Date & DCE & TCE & PCE \\
\hline \multirow{3}{*}{ N9953 } & $8-4-83$ & 84 & 480 & 3 \\
& $4-30-83$ & $<4$ & 56 & 3 \\
N9954 & $8-2-83$ & 61 & 480 & 50 \\
& $4-17-83$ & $<4$ & 92 & 31 \\
N9964 & $8-8-83$ & 62 & 290 & 410 \\
& $4-19-84$ & $<4$ & 20 & 27 \\
N9965 & $8-4-83$ & 120 & 670 & 4 \\
& $4-23-84$ & 70 & 320 & 1 \\
\hline
\end{tabular}

Much lower TCE concentrations were observed in the same wells in April 1984, after 7 months without cooling-water discharge. The data from April 1984 reflect the presence contaminated discharge of cooling water from the prior year, which had been diluted by natural recharge and dispersed during the preceding winter.

\section{Plume at Pembrook Recharge Basin}

The second discharge plume, which originates at Pembrook recharge basin (fig. 5), overlies the two other plumes that have sources farther upgradient. Prior to 1985 , cooling water contaminated by VOC's was discharged to this basin from wells N5507, N6045, N8050, and N8458 12 to 16 hours per day during warm weather. Storm runoff, which was free of VoC's, intermittently entered the basin and diluted the contaminated water. During dry summer weather, TCE concentrations in the basin remained high because of the daily discharge of contaminated cooling water; however, when the cooling-water pumps are off during winter and spring, TCE concentratons were reduced to the detection limit because only storm runoff entered the basin.

The seasonal changes in chemical quality of basin water are reflected at monitoring wells around the basin. Analyses of samples from wells N9966, $\mathrm{N} 10096$, and N10097 (on next page; data are from table 8) indicate this annual cyclic trend. Concentrations of VOCs were high in the summer of 1983 and low in the spring of 1984, which reflects dilution by the inflow of storm runoff during the preceding winter.

The August 1984 water-table map (fig. 7C) indicates that recharge at the basin also influences water at wells N9955 and N9964, which are about $300 \mathrm{ft}$ north and $150 \mathrm{ft}$ west of the basin, respectively. Well N9955, although 


\begin{tabular}{lrrrr}
\hline \multirow{2}{*}{ We11 } & Date & \multicolumn{3}{c}{ Concentration $(\mu \mathrm{g} / \mathrm{L})$} \\
\cline { 4 - 5 } N9E & TCE & PCE \\
N966 & $8-8-83$ & 40 & 320 & 55 \\
& $4-16-84$ & $<4$ & 3 & 1 \\
N10096 & $8-25-83$ & 80 & 300 & 44 \\
& $5-1-84$ & $<4$ & 19 & 1 \\
N10097 & $8-17-83$ & 45 & 250 & 39 \\
& $5-7-84$ & $<5$ & 2 & $<1$ \\
\hline
\end{tabular}

strongly influenced, shows a lag in the seasonal appearance of TCE because it is farther from the basin. Mounding of the water table below the basins (figs. $7 a-7 c$ ) caused a reversal of the regional hydraulic gradient in the water table (fig. 8) and resulted in a delayed seasonal appearance of TCE in we11 N9955 $(510 \mu \mathrm{g} / \mathrm{L}$ in November $1982,5 \mu \mathrm{g} / \mathrm{L}$ in August 1983, and $440 \mu \mathrm{g} / \mathrm{L}$ in April of 1984.

Tetrachloroethylene (observed mainly in water from cooling-water wells N5507 and N8050 and discharged to Pembrook recharge basin after use) was used to distinguish the plume originating at the recharge basins from that originating at the drain field, which contains relatively low concentrations of tetrachloroethylene. The two discharge plumes have merged in the upper glacial aquifer near Clinton Road Water Works (public-supply we1ls N3934 and N3935, screened in the Magothy aquifer and owned by the village of Garden City), directly west of Pembrook recharge basin.

TCE was detected hydraulically downgradient of the recharge basins in April and May 1984 at wells N5725 (140 $\mu \mathrm{g} / \mathrm{L})$, N6949 (12 $\mu \mathrm{g} / \mathrm{L}), N 10204$ (210 $\mu \mathrm{g} / \mathrm{L}), \mathrm{N} 10205(81 \mu \mathrm{g} / \mathrm{L})$, and $\mathrm{N} 10035(70 \mu \mathrm{g} / \mathrm{L})(\mathrm{p} 1.1)$. The seasonal fluctuation in quality of water from the basins is not readily apparent in data from well N10035, $1 / 2 \mathrm{mi}$ downgradient; evidently this distance is sufficient for dispersion and dilution to create a more homogeneous distribution of TCE. No TCE was detected in well N9398, $1 \mathrm{mi}$ downgradient of the recharge basin.

\section{Extent of TCE Contamination}

The distribution of TCE (fig. 10a) in the upper glacial aquifer was plotted from 28 water samples collected from August 1 through September 30, 1983, a period of heavy pumping. TCE and cis-1,2-dichloroethylene show a similar distribution, but TCE concentrations are higher, as shown in table 8 (at end of report). The highest concentrations of TCE (as high as $670 \mu \mathrm{g} / \mathrm{L}$ at well N9965) are associated with discharge of contaminated cooling water to the drain field. The TCE plume from Pembrook recharge basin adjoins the plume from the drain field, and both obscure the original plume. Although radial flow from water-table mounding has moved the TCE in all directions beneath both discharge sites (fig. 7C), the plumes have dispersed south-southwestward along the main direction of regional ground-water movement in the upper glacial aquifer.

The distribution of TCE in the upper glacial aquifer in April 1984, a period of light pumping (fig. 10b), was determined from 33 samples collected 
from April 2 to May 30, 1984. (See table 8.) Both plumes have basically the same configuration as in August 1984 (fig. 10a), but concentrations at the drain field and the basin are significantly lower as a result of recharge with TCE-free storm runoff between October 1983 and April 1984 and the dispersion of TCE-contaminated water discharged during the preceding summer.

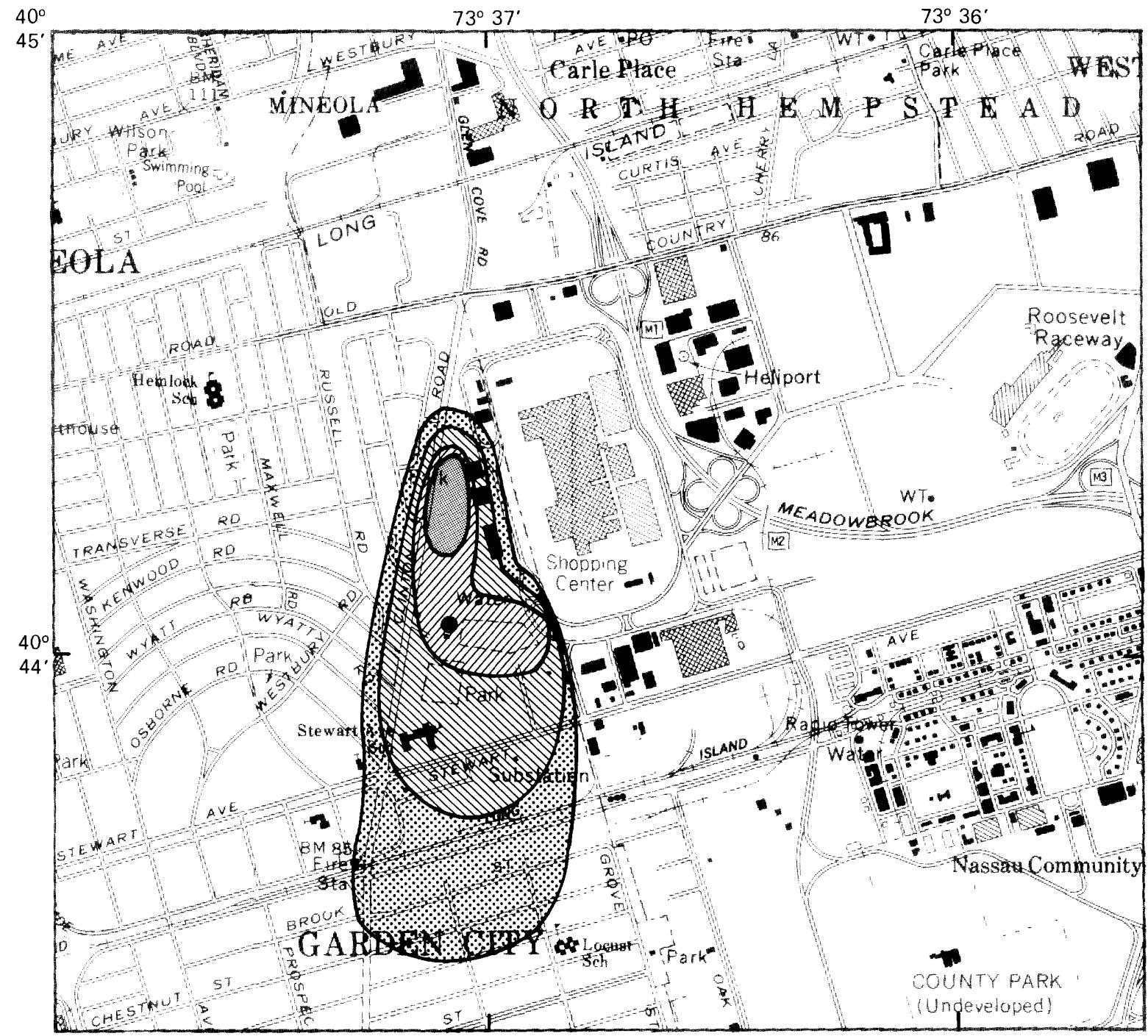

Base from NYSDOT, Freeport, NY, 1981; Lynbrook, NY, 1981;

Sea Cliff, NY, 1981; and Hicksville, NY, 1981, 1:24,000

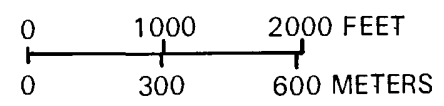

EXPLANATION

CONCENTRATION, IN MICROGRAMS PER LITER

50 to 100
100 to 250
More than 500

Figure 10A.--Trichloroethylene concentrations in the upper glacial aquifer at Roosevelt Field, August-September 1983, a period of heavy cooling-water pumping. 


\section{TCE in the Magothy Aquifer}

The spatial distribution of TCE in the Magothy aquifer (fig. 11) is less accurately delineated than in the upper glacial aquifer for several reasons. The Magothy aquifer is about $500 \mathrm{ft}$ thick at Roosevelt Field and is considerably more heterogeneous and anisotropic than the upper glacial aquifer, which has about 20 to $50 \mathrm{ft}$ of saturated thickness. Fewer wells in

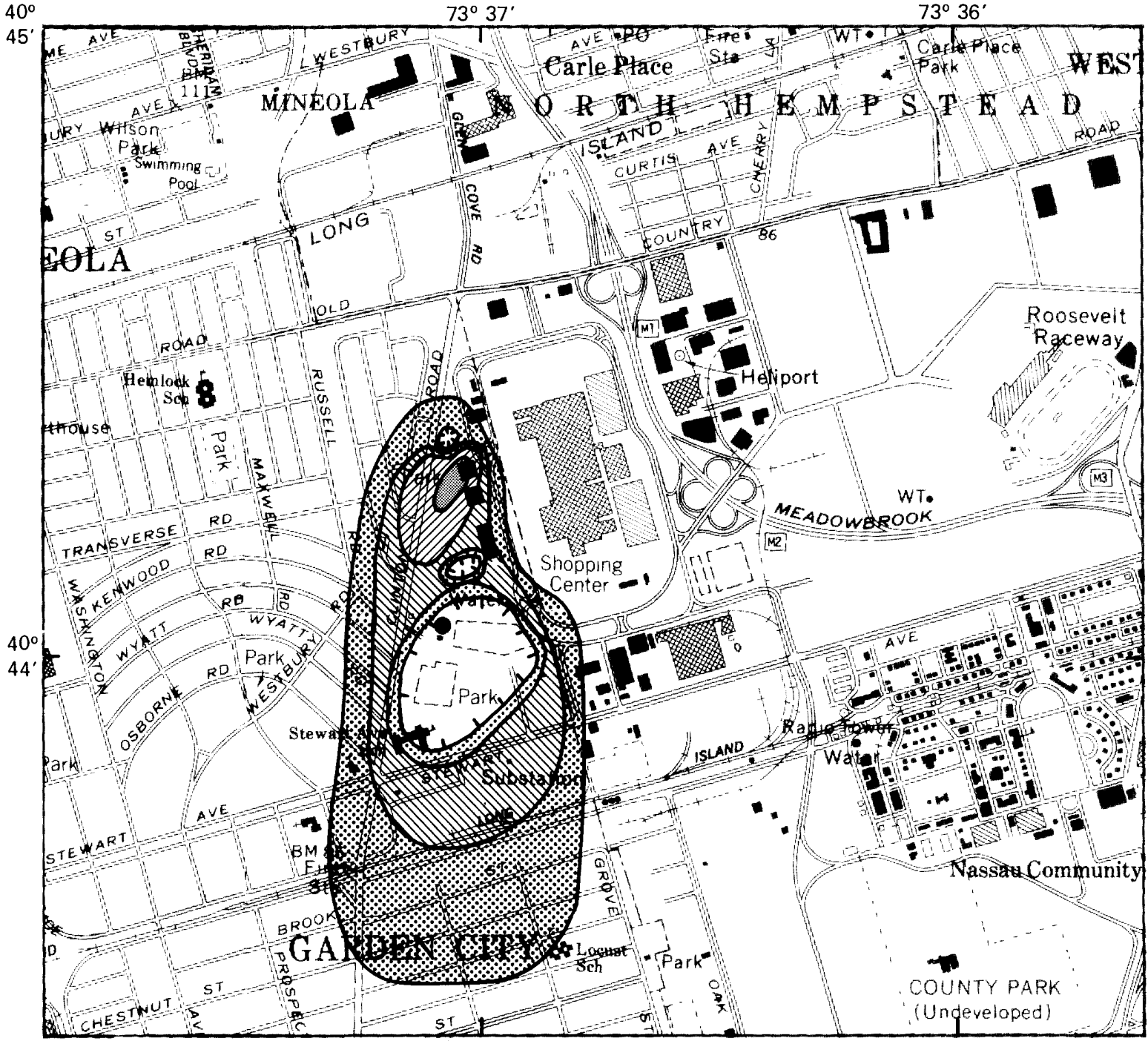

Base from NYSDOT, Freeport, NY, 1981; Lynbrook, NY, 1981;

Sea Cliff, NY, 1981; and Hicksville, NY, 1981, 1:24,000

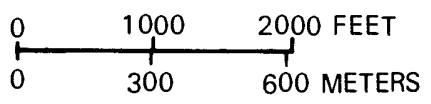

EXPLANATION

CONCENTRATION, IN MICROGRAMS PER LITER

50 to 100
100 to 250

Figure 10B.--Trichloroethylene concentrations in the upper glacial aquifer at Roosevelt Field, April-May 1984, before start of seasonal cooling-water pumping. 
the area tap the Magothy aquifer (total of 12) than the upper glacial aquifer (total of 25), and the wells are screened at variable depths (public-supply wells are screened deeper than $370 \mathrm{ft}$, whereas cooling-water supply and monitoring wells are screened less than $330 \mathrm{ft}$ deep). In general, however, contaminated water in the Magothy aquifer has been advected and dispersed south-southwestward along regional flow lines. Regional horizontal flow rates in the Magothy aquifer are less than one-third those in the upper glacial aquifer, and vertical flow rates are considerably lower because of anisotropy,

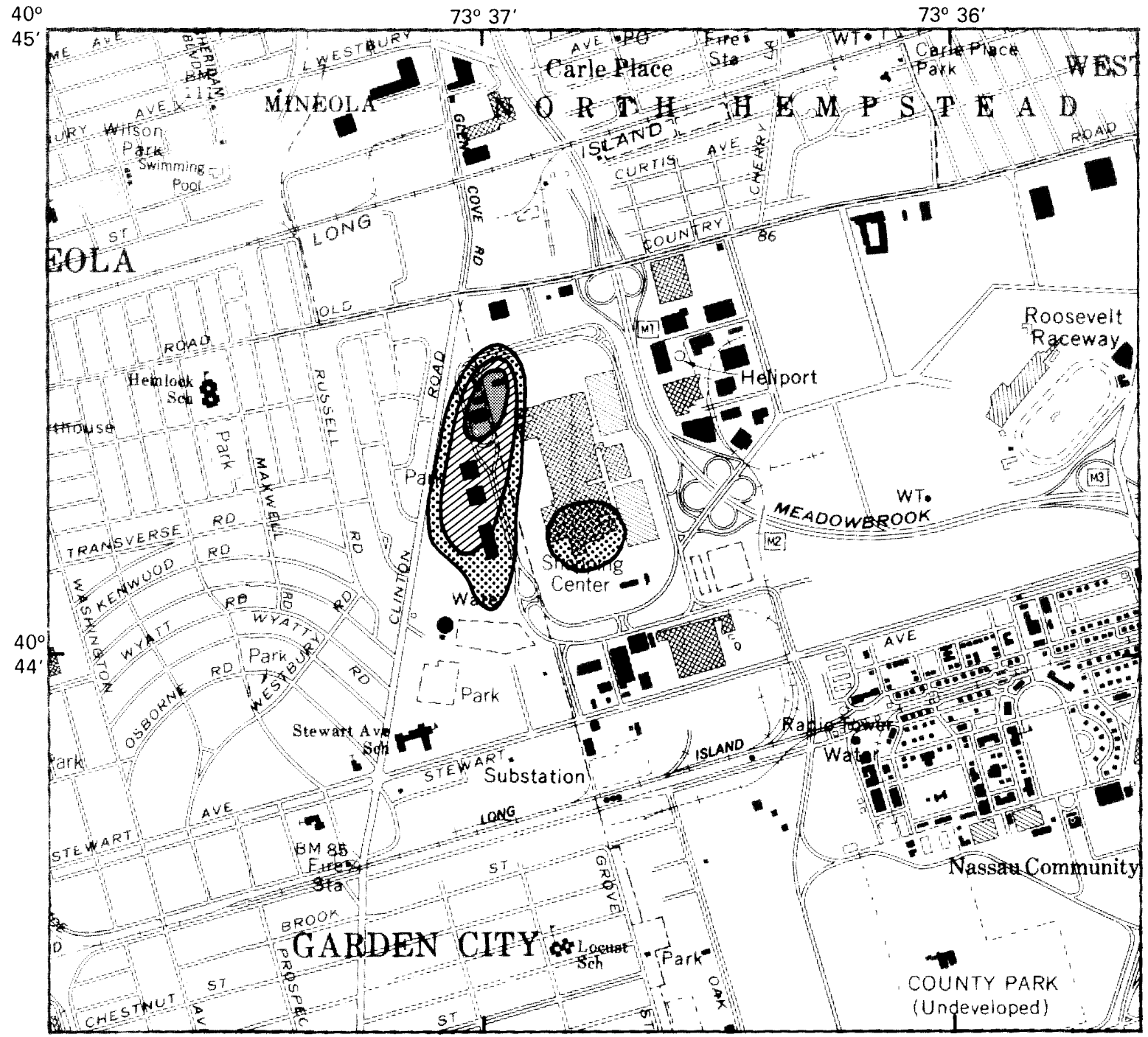

Base from NYSDOT, Freeport, NY, 1981: Lynbrook, NY, 1981:

Sea Cliff, NY, 1981; and Hicksville, NY, 1981, 1:24,000

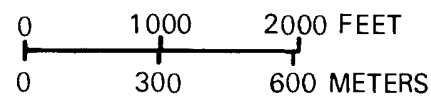

EXPLANATION

CONCENTRATION, IN MICROGRAMS PER LITER

$\square$ Less than 50
50 to $500 \quad 500$ to 3000
More than 3000

Figure 11.--Trichloroethylene concentrations in the Magothy aquifer at Roosevelt Field, April-May 1984, before start of seasonal cooling-water pumping. 
which accounts for the smaller plume (fig. 11). Also, seasonal pumping of wells for cooling water and drinking water at Roosevelt Field decreases and in some areas reverses regional hydraulic gradients near the pumping centers, thereby retarding southwestward plume movement.

The highest concentrations of TCE (and also DCE and tetrachloroethylene) observed during the 3-year study were in cooling-water wells that seasonally pump water from intermediate depths (200 to $350 \mathrm{ft}$ below land surface) in the Magothy aquifer. High TCE concentrations in three cooling-water wells--N8050, N9310, and N9311--indicate that the source of VOC contamination was northeast of these wells. The wells contained $38,000,1,300$, and $550 \mu \mathrm{g} / \mathrm{L}$ TCE respectively, in April 1984 (table 8), which define the highest concentrations in figure 11. A fourth cooling-water we11, N5507, located 1,000 ft southeast of N8050, contained $440 \mu \mathrm{g} / \mathrm{L} \mathrm{TCE}$ and $140 \mu \mathrm{g} / \mathrm{L}$ tetrachloroethylene in April 1984; the tetrachloroethylene at this well indicates a probable second source of VOC contamination at Roosevelt Field (fig. 11), but no other data verify this.

Four public-supply wells at Roosevelt Field--N3934, N3935, N5484, and N5485, screened between 370 and $572 \mathrm{ft}$ in the Magothy aquifer--contained 11 to $22 \mu \mathrm{g} / \mathrm{L}$ TCE in April 1984. A former public-supply well--N5486, directly east of Garden City Plaza--contained up to $170 \mu \mathrm{g} / \mathrm{L}$ TCE in February 1980 and for this reason was subsequently abandoned and destroyed. Geophysical and lithologic logs at well $N 5486$ indicate an absence of clay layers through the 511-ft thickness of Magothy aquifer at that location. The lack of confining layers provided a favorable pathway for the downward movement of organic contaminants from the source area to deeper zones in the Magothy aquifer. This is discussed in more detail in the following section, "Movement of TCE."

Contamination of shallow zones in the Magothy aquifer beneath the recharge basins and the drain field has probably resulted from the mounding of contaminated discharge water in the upper glacial aquifer, especially where the aquifers are in good hydraulic connection near cooling-water wells and discharge sites. Mounding increases vertical hydraulic gradients, which increases the rates of downward movement of contaminated water into the Magothy aquifer. The lack of observation wells in shallow zones of the Magothy aquifer beneath the discharge areas prevents delineation of the extent of downward movement of contamination from cooling-water discharge, however.

\section{Movement of TCE}

Advection, density-induced movement, dispersion, biochemical transformation, volatilization, and adsorption are the primary processes that affect organic-solute transport in ground water. At Roosevelt Field, regional hydraulic gradients and, to a lesser degree, gradients induced by pumping stresses, provide the dominant forces for the advective movement of organic compounds in ground water. The effects and rates of dispersion, biochemical transformation, and adsorption, which diminish concentrations of organic solutes, are less clearly defined but have been discussed by Anderson (1984), Cherry and others (1984), McCarty and others (1981), and Roberts and others (1982). 


\section{Advection}

Advective movement of an organic contaminant in ground water is the transport of the chemical with flowing water. The rate of transport is proportional to the average ground-water velocity, which is determined by the hydraulic gradients, the hydraulic conductivity, and the porosity of the aquifer material. In the absence of pumping, advective movement of organic solutes in the aquifer system at Roosevelt Field follows reglonal flow patterns--primarily horizontal but with a small vertical component. The ratio of the horfzontal component of advection to the vertical component is directly related to the anisotropy (the ratio of horizontal to vertical hydraulic conductivity, $\mathrm{K}_{\mathrm{h}}: \mathrm{K}_{\mathrm{v}}$ ), which may range from 5:1 to 24:1 in the upper glacial aquifer (LIndner and Rell1y, 1983, p. 2) and from 30:1 to 60:1 in the Magothy aquifer (Getzen, 1977).

Seasonal pumping of water from the Magothy aquifer for public supply and cooling water has altered regional gradients, however, so that contaminants in shallow aquifer zones have moved downward toward screen zones in the wells deeper in the aquifer system. Rellly (1978) and Phllips and Gelhar (1978) have shown that the major factors that affect the downward advective transport rate are hydraulic characteristics of the aquifer (including anisotropy), screen location and length, pumping rate, and regional hydraulic gradient. For deeply screened wells, the most rapld downward advective movement of contaminants is in aquifer zones where the $\mathrm{K}_{\mathrm{h}}: \mathrm{K}_{\mathrm{v}}$ ratio is lowest and pumping rates highest.

Upper glacial aquifer.--Ground water in the upper glacial aquifer moves south-southwestward along the reglonal water-table gradient with a mean velocity of about $1.0 \mathrm{ft} / \mathrm{d}$; flow within the 20 - to $40-\mathrm{ft}$ thickness of saturated upper glacial sand and gravel at Roosevelt Field is predominantly horizontal. Local water-table gradients are considerably greater than the reglonal gradients where mounding from cooling-water discharge occurs. Discharge water, which contalns dissolved organic contaminants, moves radially outward from the center of each mound, and local horizontal velocities may exceed $10 \mathrm{ft} / \mathrm{d}$ when the mound is 3 to $5 \mathrm{ft}$ above the normal water table. The increased gradients assoclated with mounding dissipate rapidly with distance from the mounds, and at distances more than 1,000 ft from each discharge site, the movement of contaminated ground water is controlled mainly by regional gradients. Mounding also increases vertical velocities below each mound, which probably results in significant downward movement of contaminated water into the Magothy aquifer. The rates of downward movement are greatest where permeable sandy zones in the Magothy aquifer are in direct hydraulic contact with the upper glacial deposits ( $K_{h}: K_{v}$ ratio is relatively low); clay zones in the top of the Magothy aquifer Impede downward movement because the $K_{h}: K_{v}$ ratio is highest in these zones.

Magothy aquifer.--Reglonal rates of ground-water movement in the Magothy aquifer are considerably lower than in the upper glaclal aquifer, and the advective movement of organic contaminants is accordingly much slower. Horlzontal ground-water velocity in the Magothy aquifer may range from negligible in clay to about $0.6 \mathrm{ft} / \mathrm{d}$ in sand under normal hydraulic gradients; average velocity is about $0.3 \mathrm{ft} / \mathrm{d}$, or one-third the average velocity in the upper glaclal aquifer. When gradlents are increased by pumping withdrawals, however, ground-water velocity increases proportionally. The velocity 
distribution in the Magothy aquifer, especially in deeper zones, is much less unfform than in the upper glacial aquifer because large intermittent withdrawals for public supply and cooling water create highly variable gradients spatially and temporally. The variability is greatest when all 11 deep-well pumps are operating on differing schedules during a typical summer day at Roosevelt Field. Under these conditions in 1983-84, rates of water movement from shallow to deeper zones in the Magothy aquifer was at least doubled at monitoring wells $900 \mathrm{ft}$ from one pumping center (fig. 9) and was more than doubled in sandy zones closer to the screens of pumping wells.

Anisotropy in the Magothy aquifer is greater than in the upper glacial aquifer, primarily because the Magothy Formation contains extensive clay layers that impede the downward movement of water. These layers are discontinuous, however, and the more permeable, coarse-grained deposits surrounding them can provide pathways for downward movement of solutes. The geologic $10 \mathrm{~g}$ of well N5486, where the deepest contamination in the Magothy aquifer was observed east of Garden City Plaza, indicates sandy zones without clay layers throughout the thickness of the aquifer. This well is near a source of contamination possibly associated with the Roosevelt Field commercial airfield, before 1950. The high vertical hydraulic conductivity in this area of heavy pumping has allowed higher-than-normal rates of vertical movement of water (and dissolved contaminants) during pumping periods. During peak demand for ground water in the summer (1982-84), about 6.2 Mgal/d of water was pumped from middle and basal sections at Roosevelt Field. Although pumping stresses were not continuous (fig. 9), the transient increases in downward movement of water have become significant over time. Under predevelopment flow conditions (unaffected by man's activities), recharge to the aquifer system from precipitation at Roosevelt Field would mostly follow the lateral gradients and would not reach $500 \mathrm{ft}$ below land surface until far from the Roosevelt Field area (Franke and Cohen, 1972, p. 273). The presence of TCE and DCE $500 \mathrm{ft}$ below land surface at well N5486 indicates that the natural flow patterns and contaminant movement in the aquifer system in this area have been significantly altered by pumping.

\section{Density-Induced Movement}

Density-induced downward movement of undissolved heavy organic solvents may partly account for the presence of TCE in the basal section of the Magothy aquifer at Roosevelt Field. TCE is about 1.5 times heavier than native ground water. When TCE is present as an organic (hydrophobic) phase, it will displace water and sink as it dissolves. Vertical movement of a hydrophobic phase would be impeded by low-permeability sediments such as clay layers. Although density-induced movement may have been significant in the early stages of the contaminant entry in the aquifer system, no evidence for the presence of a hydrophobic phase of TCE has been found to date at Roosevelt Field, and the movement of VOC's is probably controlled mainly by hydraulic gradients of natural flow patterns and from pumping.

\section{Biodegradation}

Recently, Parsons and others (1984) and Kleopfer and others (1985) have demonstrated the dechlorination of TCE by bacteria under anaerobic conditions. 
The primary dechlorination product was cis-1,2-dichloroethylene. This isomer was commonly detected in ground water containing TCE contamination at Roosevelt Field, which indicates the possible microbial metabolism of TCE. Parsons and others (1984) and Kleopfer and others (1985) also suggest that dichloroethylene is dechlorinated to form vinyl chloride; analysis of contaminated ground water at Roosevelt Field, however, did not include vinyl chloride.

\section{Adsorption}

Physical adsorption of organic contaminants to clastic and organic particles depends on the physical-chemical interaction of the compounds and the aquifer media. The adsorption of nonpolar organic solutes to sediment particles and particle coatings is directly proportional to the organic carbon content of the adsorbing media (Karickhoff and others, 1979; Schwarzenbach and Westa11, 1981). Chiou and others (1979), who prefer to view the uptake of

Table 5.--Total organic carbon in core samples from well $N 10042$ at Mitchel Field in central Nassau County, New York.

\begin{tabular}{|c|c|c|}
\hline $\begin{array}{l}\text { Depth } \\
\text { (feet) }\end{array}$ & $\begin{array}{l}\text { Percent } \\
\text { organic } \\
\text { carbon }\end{array}$ & Lithologic description \\
\hline & & Magothy aquifer \\
\hline $\begin{array}{l}144 \\
154 \\
164 \\
174 \\
184\end{array}$ & $\begin{array}{r}0.52 \\
.59 \\
.04 \\
19 . \\
2.3\end{array}$ & $\begin{array}{l}\text { Sand, gray, fine to medium, clayey. } \\
\text { Sand, gray, fine to medium, silty. } \\
\text { Sand, brown, fine to coarse, silty. } \\
\text { Clay, black, IIgnitic, slightly silty. } \\
\text { Clay, gray, IIgnitic, silty. }\end{array}$ \\
\hline $\begin{array}{l}194 \\
204 \\
214 \\
224 \\
234\end{array}$ & $\begin{array}{r}2.3 \\
.61 \\
4.1 \\
17 . \\
.20\end{array}$ & $\begin{array}{l}\text { Clay, black, lignitic, micaceous. } \\
\text { Sand, gray, fine to medium, silty. } \\
\text { Sand, gray, fine to medium, lignitic. } \\
\text { Lignite, black, clayey. } \\
\text { Sand, gray, fine to coarse, micaceous. }\end{array}$ \\
\hline $\begin{array}{l}244 \\
264 \\
274 \\
284 \\
294\end{array}$ & $\begin{array}{l}4.3 \\
.04 \\
.13 \\
.06 \\
.04\end{array}$ & $\begin{array}{l}\text { Clay, gray, slightly lignitic, silty. } \\
\text { Sand, orange, fine to coarse, silty. } \\
\text { Sand, brown-gray, fine to medium. } \\
\text { Sand, gray, fine to medium, silty, micaceous. } \\
\text { Sand, brown-gray, fine to coarse. }\end{array}$ \\
\hline $\begin{array}{l}394 \\
464 \\
524\end{array}$ & $\begin{array}{l}2.0 \\
.03 \\
<.01\end{array}$ & $\begin{array}{l}\text { Sand, gray, medium to coarse, lignitic. } \\
\text { Sand, brown, fine to medium. } \\
\text { Sand, brown, coarse; gravel, granule to pebble. } \\
\text { Raritan confining unit }\end{array}$ \\
\hline $\begin{array}{l}624 \\
644 \\
664 \\
671\end{array}$ & $\begin{array}{l}.51 \\
19.06 \\
17 .\end{array}$ & $\begin{array}{l}\text { Clay, gray, silty. } \\
\text { Sand, gray, fine to medium, slightly clayey. } \\
\text { Lignite, black; clay, gray, silty. } \\
\text { Lignite, black; clay, gray, silty. }\end{array}$ \\
\hline
\end{tabular}


organic solutes by the medium as a reversible equilibrium-partitioning process rather than an adsorption process, have shown that isotherms for chlorinated organic solutes such as TCE are essentlally linear and that their slopes are Inversely proportional to each compound's solubility. Nonpolar organic solutes such as TCE, which have moderately low solubility in water, tend to adsorb readily to organic material in the aquifers. Sorptive effects of the inorganic fraction of aquifer material, such as clay minerals, seem to be negligible when the organic fraction exceeds 1 percent (Karickhoff and others, 1979). In aquifers that are deficlent in organic carbon, such as the upper glacial aquifer, TCE's high mobility is therefore probably due in part to the low adsorptive capability of the medium.

The content of organic carbon in aquifer material at one well in the Roosevelt Field area is reported in table 5. Samples from the Magothy aquifer at well N10042 were taken from split-spoon cores $2 \mathrm{mi}$ southeast of Roosevelt Field and analyzed for total organic carbon by the U.S. Geological Survey National Water-Quality Laboratory in Doraville, $\mathrm{Ga}$. In general, sandy zones contain 1ittle organic carbor, whereas clay zones with abundant lignite may contain up to 23 percent organic carbon. These lignitic clay zones in the Magothy aquifer are laterally discontinuous and generally transmit water very slowly. The more permeable sandy zones, which transmit more water, may contain less than 1 percent organic carbon. Thus, the zones through which water moves most rapidly probably do not have the capacity to significantly attenuate organic solute transport by adsorption, which helps explain the continuing presence of TCE at lower depths in the Magothy aquifer.

\section{SUMMARY AND CONCLUSIONS}

In 1982, the U.S. Geological Survey began a study in cooperation with Nassau County to evaluate the occurrence and movement of chlorinated volatile organic compounds (VOC's) in ground water at Roosevelt Field, an area in central Nassau County where five public-supply wells have been affected by trichloroethylene (TCE) contamination. of five public-supply wells and seven cooling-water supply wells at Roosevelt Field, six have ylelded water that contains TCE In excess of New York State drinking-water guidelines. One cooling-water well that taps the Magothy aquifer has yielded water that contains $38,000 \mu \mathrm{g} / \mathrm{L}$ of TCE. The area was once an active commerclal airfield but is now a large shopping mall and offlce-bullding complex. The source of the contamination has not been 1dentified.

The aquifer system in central Nassau County consists of unconsolidated Pleistocene and Cretaceous deposits of gravel, sand, silt, and clay. The upper glaclal aquifer, which contains the water table, overlies the Magothy aquifer and is in direct hydraulic contact with it. The upper glacial aquifer consists of 20 to $40 \mathrm{ft}$ of saturated Plelstocene sand and gravel. Depth to water ranges from 25 to $50 \mathrm{ft}$. The Magothy aquifer, which overlies the Raritan confining unit, consists of alternating sequences and gradations of sand, silt, clay, and lignite, with gravel in the basal section. The Magothy 
aquifer is about $500 \mathrm{ft}$ thick at Roosevelt Field; the lower $150 \mathrm{ft}$ provides most of the public-water supply. The Raritan confining unit and the Lloyd aquifer beneath form the base of the aquifer system, but no hydrologic or water-quality data are available from the Roosevelt Field area.

The regional movement of ground water in the upper glacial aquifer is south-southwestward from the mid-island ground-water divide, about 2 mi north of Roosevelt Field, to discharge areas near and beyond the south shore in southeastern Queens County and southwestern Nassau County. The regional water-table gradient at Roosevelt Field averages about 0.0012 , and the average rate of horizontal movement is about $1 \mathrm{ft} / \mathrm{d}$. Flow rates in the Magothy aquifer, which is much finer grained and has a lower mean hydraulic conductivity, range from negligible to $0.6 \mathrm{ft} / \mathrm{d}$. The downward component of flow in the Magothy aquifer under natural conditions may range from $1 / 30$ to $1 / 60$ of the horizontal flow. Ground-water withdrawals from middle and basal sections of the Magothy aquifer induce higher rates of downward flow, especially during periods of peak demand for water supply in the summer.

During 1982-84, four public-supply wells at Roosevelt Field pumped more than $4 \mathrm{Mgal} / \mathrm{d}$ during peak water demand in the summer, and seven wells for cooling water pumped an additional $4 \mathrm{Mgal} / \mathrm{d}$ during warm weather. Water from the cooling-water wells was discharged to the upper glacial aquifer after use at two locations during the summer cooling season, typically from May to September. One location was the 2.5-acre Pembrook recharge basin, excavated in sand and gravel in southwestern Roosevelt Field, to which about $2 \mathrm{Mgal} / \mathrm{d}$ of wastewater from four cooling-water wells was discharged. The discharge water contained TCE, cis-1,2-dichloroethylene (DCE), and tetrachloroethylene (PCE which was pumped from the Magothy aquifer. The second discharge location was a subsurface drain field at the Garden City Plaza office-building complex, to which about $2 \mathrm{Mgal} / \mathrm{d}$ of wastewater from two cooling-water wells was discharged. This wastewater also contained TCE and DCE and was pumped from the Magothy aquifer, but the water was partially treated by aeration stripping before it was discharged.

Water-table mounds form beneath both discharge sites during the summer cooling season. In 1982-84, the mound beneath Pembrook recharge basin persisted throughout the year because the basin also received storm runoff, but then rose to 3 to $4 \mathrm{ft}$ above the regional water-table during the summerdischarge period. In August 1984, the discharge to the basin contained 13 $\mathrm{lb} / \mathrm{d}$ of TCE and $3.2 \mathrm{lb} / \mathrm{d}$ of PCE. The mound beneath the Garden City Plaza drain field also was observed from May through September 1984, when it was 4 to $5 \mathrm{ft}$ higher than the regional water table. Although the discharge was treated by aeration to remove VOC's, the treatment was only about 44 percent effective in August 1984. At that time, the treated discharge contained 9.6 $\mathrm{lb} / \mathrm{d}$ of TCE and $1.3 \mathrm{lb} / \mathrm{d}$ of DCE.

Ground water was sampled for VOC's and common inorganic chemical constituents in public-supply wells, cooling-water supply wells, and monitoring wells during the summer of 1983 and the spring of 1984. In 1984, TCE was detected in 44 of 105 wells, and concentrations ranged from less than the detection 1imit $(1 \mu \mathrm{g} / \mathrm{L})$ to $38,000 \mu \mathrm{g} / \mathrm{L}$. Concentrations of DCE ranged from less than detection limit to $2,800 \mu \mathrm{g} / \mathrm{L}$, and PCE concentrations ranged from less than detection limit to $350 \mu \mathrm{g} / \mathrm{L}$. 
Three plumes of trichloroethylene contamination have been delineated at Roosevelt Field, two of which are formed by the seasonal discharge of contaminated cooling water and overlie the original plume, which is in the upper glacial and Magothy aquifers. One plume originated at the drain field; the other originated at the Pembrook recharge basin, 1,000 ft downgradient of the drain field. Contaminated water moved radially from each cooling-water discharge center, where local flow rates may have exceeded $10 \mathrm{ft} / \mathrm{d}$. The two plumes have merged in southwestern Roosevelt Field and extend more than 1,000 ft to the south-southwest along the axis of regional flow in the upper glacial aquifer. The concentrations of inorganic chemical constituents in the two discharge plumes are similar to those in ambient ground water. The two plumes differ, however, in that the discharge from Pembrook recharge basin contains TCE, PCE, and DCE, whereas the discharge from the drain field contains only TCE and DCE.

Discharge of contaminated cooling water ceased during the winter, and the inflow of uncontaminated storm runoff to the recharge basin dispersed the ground water contaminated by the preceding summer's discharge. Ground-water quality and temperature in monitoring wells around the basin fluctuated seasonally and reflect the quality and temperature of water that is discharged to the basin. Concentrations of TCE at one monitoring well (N10097) at the edge of the basin seasonally ranged from 3 to $300 \mu \mathrm{g} / \mathrm{L}$, and temperature ranged from $7.3^{\circ} \mathrm{C}$ to $22.6^{\circ} \mathrm{C}$. The magnitude of fluctuation in TCE concentration and temperature decreases with distance from the basin, and no seasonal variations were detected at monitoring wells $1,000 \mathrm{ft}$ downgradient.

Although the Magothy aquifer is 10 to 15 times thicker than the upper glacial aquifer, the number of wells that tap it at Roosevelt Field is small; thus, the distribution of TCE and DCE in the Magothy is less accurately delineated than in the upper glacial aquifer. Concentrations of TCE exceeded $38,000 \mu \mathrm{g} / \mathrm{L}$ in 1984 in a cooling-water well (N8050) screened $300 \mathrm{ft}$ deep, directly north of Garden City Plaza, and were $170 \mu \mathrm{g} / \mathrm{L}$ in an adjacent public-supply well (N5486) screened at $450 \mathrm{ft}$ when the well was abandoned and destroyed in 1980. Four other public-supply wells, all screened below $400 \mathrm{ft}$, have TCE concentrations that are detectable but less than $50 \mu \mathrm{g} / \mathrm{L}$. Tetrachloroethylene was detected in only one cooling-supply well (N5507) and indicates a separate source of VOC contamination. The two cooling-water wells (N5507 and N8050) that contributed contaminated discharge to Pembrook recharge basin were both abandoned in 1985, thereby stopping the inflow of contaminants to the basin.

The contaminated zone in the Magothy aquifer contains high concentrations of TCE and DCE associated with the unknown source of contamination; the plume is elongated and diffused south-southwestward along regional flow lines. Regional flow rates in the Magothy aquifer are less than $1 / 3$ the flow rates in the upper glacial aquifer, and the plume area is proportionately much smaller. At Roosevelt Field, the heterogeneity and anisotropy of the Magothy aquifer, combined with the effects of increased vertical hydraulic gradients from ground-water withdrawals, create a highly variable velocity distribution. In addition, increased pumping for cooling-water supplies during warm weather increases hydraulic gradients near each pumping center. A sandy vertical zone that lacks clay layers provides good vertical hydraulic connection in the aquifer system in the area of a possible contaminant source near abandoned 
public-supply well N5486. Pumping from middle and basal sections of the Magothy aquifer in this area has increased the rates of downward contaminant advection, especially during summer, when pumpage has exceeded $6 \mathrm{Mgal} / \mathrm{d}$. This advection has been cumulative through time and has transported TCE and associated contaminants as deeply as the basal section of the aquifer, $500 \mathrm{ft}$ below land surface. Thus, the combined effects of horizontal flow along the regional hydraulic gradient, which controls the regional flow of ground water when pumping is at a minimum during cool weather, and increased downward flow induced by pumping during warm weather have moved and dispersed the VOC contaminants in the aquifer system. This movement and dispersion has caused TCE and DCE to reach the base of the Magothy aquifer at Roosevelt Field in less than 40 years of transit, which indicates that natural flow patterns in this area have been significantly altered by pumping.

\section{REFERENCES CITED}

Anderson, M. P., 1984, Movement of contaminants in groundwater--groundwater transport-advection and dispersion, in Studies in geophysics, groundwater contamination: National Academy Press, p. 37-45.

Cherry, J. A., Gillham, R. W., and Barker, J. F., 1984, Contaminants in groundwater--chemical processes, in Studies in geophysics, groundwater contamination: National Academy Press, p. 46-64.

Chiou, C. T., Peters, L. J., and Freed, V. H., 1979, A physical concept of soil-water equilibria for nonionic organic compounds: Science, v. 206, p. 831-832.

Cohen, Philip, Franke, 0. L., and Foxworthy, B. L., 1968, An atlas of Long Island's water resources: New York State Water Resources Commission Bulletin 62, $117 \mathrm{p}$.

Dilling, W. L., Tefertiller, N. B., and Kallos, G. J., 1975, Evaporation rates and reactivities of methylene chloride, chloroform, 1,1,1-trichloroethane, trichloroethylene, tetrachloroethylene, and other chlorinated compounds in dilute aqueous solutions: Environmental Science and Technology, v. 9, no. 9, p. 833-838.

Donaldson, C. D., and Koszalka, E. J., 1983a, Potentiometric surface of the Magothy aquifer, Long Island, New York, in March 1979: U.S. Geological Survey Open-File Report 82-160, 2 sheets, scale 1:125,000.

$1983 \mathrm{~b}$, Potentiometric surface of the Lloyd aquifer, Long Island, in January 1979: U.S. Geological Survey Open-File Report 82-162, 2 sheets, scale $1: 125,000$.

1983c, Water table on Long Island, New York, March 1979: U.S. Geological Survey Open-File Report 82-163, 2 sheets, scale 1:125,000.

Franke, 0. L., and Cohen, Philip, 1972, Regional rates of ground-water movement on Long Island, New York: U.S. Geological Survey Professional Paper 800-C, p. C271-277. 


\section{REFERENCES CITED (Continued)}

Franke, 0. L., and McClymonds, N. E., 1972, Summary of the hydrologic situation on Long Island, New York, as a guide to water-management alternatives: U.S. Geological Survey Professional Paper 627-F, 59 p.

Getzen, R. T., 1977, Analog-model analysis of regional three-dimensional flow in the ground-water reservoir of Long Island, New York: U.S. Geological Survey Professional Paper 982, 49 p.

Isbister, John, 1966, Geology and hydrology of northeastern Nassau County, Long Island, New York: U.S. Geological Survey Water-Supply Paper 1825, $89 \mathrm{p}$.

Karickhoff, S. W., Brown, D. S., and Scott, T. A., 1979, Sorption of hydrophobic pollutants on natural sediments: Water Research, v. 13, no. 3 , p. 241-248.

Katz, B. G., and Lindner, J. B., 1978, Nitrogen concentration in Nassau County ground water from early 1950's through 1976 [abstract]: Adelphi, N.Y., American Chemical Society Conference, April 23, 1978, 1 p.

Kilburn, Chabot, 1979, Hydrogeology of the Town of North Hempstead, Nassau County, Long Island, New York: Long Island Water Resources Bulletin 12, $87 \mathrm{p}$.

Kilburn, Chabot, and Krulikas, R. K., 1987, Hydrogeology and ground-water quality of the northern part of the Town of Oyster Bay, Nassau County, New York, in 1980: U.S. Geological Survey Open-File Report 85-4051, $61 \mathrm{p}$.

Kleopfer, R. D., Easley, D. M., Haas, B. B., Diehl, T. G., Jackson, D. E., and Wurrey, C. J., 1985, Anaerobic degradation of trichloroethylene in soil: Environmental Science and Technology, v. 19, no. 3, p. 277-280.

Lindner, J. B., and Reilly, T. E., 1983, Analysis of three tests of the unconfined aquifer in southern Nassau County, Long Island, New York: U.S. Geological Survey Water-Resources Investigations Report 82-4021, $52 \mathrm{p}$.

Mackay, S. L., Fleisher, M. B., and Cusumano, R. D., 1979, Inventory for "Report on survey of consumer products containing or suspected of containing harmful organic chemicals and having the potential of contaminating the ground water of Nassau County, New York: Nassau County Department of Health, $17 \mathrm{p}$.

McCarty, P. L, Reinhard, M., and Rittmann, B. E., 1981, Trace organics in ground water: Environmental Science and Technology, v. 15, no. 1, p. 40-51.

McClymonds, N. E., and Franke, O. L., 1972, Water-transmitting properties of aquifers on Long Island, New York: U.S. Geological Survey Professional Paper 627-E, $24 \mathrm{p}$. 


\section{REFERENCES CITED (Continued)}

Miller, J. F., and Frederick, R. H., 1969, The precipitation regime of Long Island, New York: U.S. Geological Survey Professional Paper 627-A, 21 p.

Myott, D. H., 1980, Groundwater qual1ty assessment, Nassau County, New York, 1978 report year: Nassau County Department of Health, 39 p.

Narang, R. S., and Bush, D., 1980, Determination of arenes, vinyl chloride, and other volatile haloorganic compounds in water at microgram-per-liter levels by gas chromatography: Analytical Chemistry, v. 52, no. 13, p. 2076-2079.

National Academy of Sciences, 1977, Drinking water and health: National Research Council, Washington, D.C., 939 p.

Parsons, Frances, Wood, P. R., and DeMarco, Jack, 1984, Transformations of tetrachloroethene and trichloroethene in microcosms and groundwater: Journal of American Water Works Association, v. 76, no. 2, p. 56-59.

Pearsa11, K. A., and Eckhardt, D. A., 1987, Effects of selected sampling equipment and procedures on the concentrations of trichloroethylene and related compounds in ground-water samples: Ground Water Monitoring Review, v. 7, no. 2, p. 64-73.

Perlmutter, N. M., and Geraghty, J. J., 1963, Geology and ground-water conditions in southern Nassau and southeastern Queens Counties, Long Island, New York: U.S. Geological Survey Water-Supply Paper 1613-A, 205 p.

Philips, K. J., and Gelhar, L. W., 1978, Contaminant transport to deep wells: American Society of Civil Engineers Journal of the Hydraulics Division, proceedings, v. 104, no. HY6, p. 807-819.

Reilly, T. E., 1978, Convective contaminant transport to pumping well: American Society of Civil Engineers Journal of the Hydraulics Division proceedings, v. 104, no. HY12, p. 1565-1575.

Roberts, P. V., Reinhard, M., and Valocchi, A. J., 1982, Movement of organic contaminants in ground water--implications for water supply: Journal of American Water Works Association, v. 74, no. 8, p. 408-413.

Schwarzenbach, R. P., and Westall, John, 1981, Transport of nonpolar organic compounds from surface water to ground water--laboratory sorption studies: Environmental Science and Technology, v. 15, no. 11, p. $1360-1367$.

Skougstad, M. W., Fishman, M. J., Friedman, L. C. Erdmann, D. E. and Duncan, S. S., eds., 1979, Methods for determination of inorganic substances in water and fluvial sediments: Techniques of Water-Resources Investigations of the U. S. Geological Survey, Book 5, Laboratory Analysis, Chapter A1, 626 p. 


\section{REFERENCES CITED (continued)}

Swarzenski, W. V., 1963, Hydrogeology of northwestern Nassau and northeastern Queens Counties, Long Island, New York: U.S. Geological Survey Water-Supply Paper 1657, 90 p.

U.S. Environmental Protection Agency, 1979a, Methods for chemical analysis of water and wastes: Cincinnati, Ohio, Environmental Monitoring and Support Laboratory, Office of Research and Development, U.S. Environmental Protection Agency Publication EPA-600/4-79-020, 460 p.

$1979 \mathrm{~b}$, Water-related environmental fate of 129 priority pollutants--volume II: Washington, D.C., Office of Water Planning and Standards, U.S. Environmental Protection Agency Publication EPA-440/4-79-029b, p. 52:1-52:13.

U.S. Environmental Protection Agency, 1979c, Status assessment of toxic chemicals--Trichloroethylene: Cincinnati, Ohio, Industrial and Environmental Research Laboratory, Office of Research and Development, U.S. Environmental Protection Agency Publication EPA-600/2-79-210m, 25 p.

Wershaw, R.L., Fishman, M. J. Grabbe, R. R. and Lowe, L. E. 1982, Methods for analysis of organic substances in water: U.S. Geological Survey Open-File Report 82-1004, 180 p. 
Table 6.--Data on wells in the Roosevelt Field area, Nassau County, New York

\begin{tabular}{|c|c|c|c|c|c|c|}
\hline \multirow[b]{2}{*}{ We11 } & \multirow[b]{2}{*}{$\begin{array}{c}\text { Lat } \\
0\end{array}$} & \multirow[b]{2}{*}{$\begin{array}{c}\text { Long Itude } \\
\end{array}$} & \multirow[b]{2}{*}{ Owner } & \multicolumn{3}{|c|}{$\begin{array}{l}\text { Depth to screen, in } \\
\text { feet below land surface }\end{array}$} \\
\hline & & & & $\begin{array}{l}\text { Top } \\
\text { (feet) }\end{array}$ & $\begin{array}{l}\text { Bottom } \\
\text { (feet) }\end{array}$ & $\begin{array}{l}\text { Diameter } \\
\text { (Inches) }\end{array}$ \\
\hline 79 & 404252 & 733714 & V11lage of Hempstead & 338 & 428 & 10 \\
\hline 80 & 404256 & 733712 & V11lage of Hempstead & 428 & 478 & 16 \\
\hline 81 & 404305 & 733709 & V1llage of Hempstead & 360 & 420 & 28 \\
\hline 82 & 404308 & 733707 & V1llage of Hempstead & 390 & 542 & -- \\
\hline 83 & 404306 & 733713 & V1llage of Hempstead & 363 & 403 & 28 \\
\hline 94 & 404350 & 733825 & V1llage of Garden City & 322 & 372 & 18 \\
\hline 95 & 404352 & 733830 & Village of Garden City & 474 & 534 & 20 \\
\hline 97 & 404448 & 733812 & Village of Garden City & 310 & 369 & 16 \\
\hline 101 & 404521 & 733534 & Village of Westbury & 280 & 340 & 18 \\
\hline 1139 & 404415 & 733803 & Nassau County & 65 & 68 & 2 \\
\hline 1141 & 404304 & 733752 & Nassau County & 40 & 43 & 1 \\
\hline 1160 & 404359 & 733616 & Nassau County & 53 & 58 & 4 \\
\hline 1180 & 404411 & 733437 & Nassau County & 30 & 32 & 1 \\
\hline 1451 & 404355 & 733711 & Nassau County & 32 & 35 & 1 \\
\hline 1697 & 404357 & 733837 & Village of Garden City & 478 & 518 & 24 \\
\hline 2418 & 404403 & 733631 & Unknown & 40 & 55 & 10 \\
\hline 2419 & 404402 & 733636 & Unknown & 37 & 58 & 12 \\
\hline 2747 & 404446 & 733650 & V1llage of Carle Place & 278 & 328 & 18 \\
\hline 2748 & 404445 & 733651 & Village of Carle Place & 460 & 510 & 16 \\
\hline 3185 & 404416 & 733847 & Village of Mineola & 423 & 463 & 10 \\
\hline 3699 & 404446 & 733713 & Destroyed & 67 & 89 & 10 \\
\hline 3700 & 404448 & 733705 & Destroyed & 52 & 73 & 10 \\
\hline 3890 & 404455 & 733700 & Unknown & 22 & 33 & 6 \\
\hline 3934 & 404402 & 733708 & Village of Garden City & 377 & 417 & 18 \\
\hline 3935 & 404400 & 733705 & Village of Garden City & 370 & 410 & 18 \\
\hline 4082 & 404525 & 733732 & Village of Mineola & 422 & 462 & 18 \\
\hline 4206 & 404524 & 733632 & Village of Carle Place & 305 & 355 & 18 \\
\hline 4425 & 404259 & 733715 & Village of Hempstead & 325 & 365 & 20 \\
\hline 4772 & 404437 & 733743 & Destroyed & 197 & 237 & 6 \\
\hline 5484 & 404420 & 733644 & Town of Hempstead & 500 & 572 & 20 \\
\hline 5485 & 404423 & 733655 & Town of Hempstead & 473 & 554 & 20 \\
\hline 5486 & 404415 & 733655 & Town of Hempstead & 450 & 556 & 20 \\
\hline 5507 & 404413 & 733647 & R.H. Macy and Company & 107 & 330 & 16 \\
\hline 5596 & 404454 & 733726 & Village of Mineola & 403 & 463 & 18 \\
\hline 5654 & 404451 & 722526 & Village of WEstbury & 275 & 335 & 20 \\
\hline 5725 & 404348 & 733649 & Newsday, Inc. & 46 & 56 & 10 \\
\hline 6045 & 404432 & 733656 & Town of Hempstead & 277 & 328 & 16 \\
\hline 6046 & 404416 & 733548 & Town of Hempstead & 145 & 175 & 10 \\
\hline 6315 & 404526 & 733626 & V1llage of Carle Place & 298 & 348 & 12 \\
\hline 6512 & 404428 & 733636 & Island Heliport, Inc. & 61 & 71 & 6 \\
\hline 6545 & 404426 & 733636 & Island Hellport, Inc. & 30 & 40 & 6 \\
\hline 6841 & 404438 & 733610 & Island Inn & 312 & 337 & 8 \\
\hline 6842 & 404442 & 733610 & Island Inn & 143 & 158 & 6 \\
\hline 6949 & 404351 & 733648 & Newsday, Inc. & 41 & 46 & 6 \\
\hline 6951 & 404439 & 733614 & Avis International, Inc. & 304 & 334 & 12 \\
\hline
\end{tabular}


Table 6.--Data on wells in the Roosevelt Field area, Nassau County, New York (cont.)

\begin{tabular}{|c|c|c|c|c|c|c|}
\hline \multirow[b]{2}{*}{ We11 } & \multirow[b]{2}{*}{$\begin{array}{l}\text { Latitude } \\
\end{array}$} & \multirow[b]{2}{*}{$\begin{array}{l}\text { Longitude } \\
\end{array}$} & \multirow[b]{2}{*}{ Owner } & \multicolumn{3}{|c|}{$\begin{array}{c}\text { Depth to screen, in } \\
\text { feet below land surface } \\
\end{array}$} \\
\hline & & & & $\begin{array}{l}\text { Top } \\
\text { (feet) }\end{array}$ & $\begin{array}{l}\text { Bottom } \\
\text { (feet) }\end{array}$ & $\begin{array}{l}\text { Diameter } \\
\text { (inches) }\end{array}$ \\
\hline 6994 & 404418 & 733617 & Georgian-Web Press, Inc. & 250 & 270 & 8 \\
\hline 6998 & 404438 & 733607 & Island Inn & 39 & 60 & 6 \\
\hline 7174 & 404317 & 733632 & M.C.M. Beverage Company & 57 & 67 & 20 \\
\hline 7298 & 404303 & 733714 & Village of Hempstead & 394 & 444 & 20 \\
\hline 7500 & 404419 & 733450 & Nassau County & 405 & 458 & 20 \\
\hline 7785 & 404526 & 733534 & Village of Westbury & 330 & 400 & 20 \\
\hline 7957 & 404420 & 733531 & Town of Hempstead & 433 & 519 & 20 \\
\hline 8007 & 404543 & 733549 & Village of Westbury & 490 & 564 & 20 \\
\hline 8050 & 404422 & 733700 & Bernhardt and Stein, Inc. & 300 & 328 & 8 \\
\hline 8068 & 404357 & 733646 & VMI, Inc. & 265 & 291 & 10 \\
\hline 8305 & 404453 & 733713 & BOCES & 51 & 60 & 8 \\
\hline 8457 & 404457 & 733607 & Village of Carle Place & 355 & 435 & 20 \\
\hline 8458 & 404422 & 733644 & Pembrook Management, Inc. & 290 & 350 & 12 \\
\hline 8474 & 404325 & 733630 & Town of Hempstead & 485 & 556 & 20 \\
\hline 8475 & 404325 & 733630 & Town of Hempstead & 409 & 481 & 20 \\
\hline 8576 & 404453 & 733834 & Village of Mineola & 445 & 505 & 12 \\
\hline 8598 & 404239 & 733555 & Nassau County & 42 & 45 & 1 \\
\hline 8666 & 404418 & 733702 & VMI, Inc. & 43 & 67 & 8 \\
\hline 8682 & 404440 & 733529 & Uman Parante Company & 89 & 94 & 8 \\
\hline 8753 & 404440 & 733529 & Uman Parante Company & 100 & 110 & 8 \\
\hline 8958 & 404306 & 733537 & Nassau County & 30 & 35 & 2 \\
\hline 8971 & 404344 & 733543 & Nassau County & 30 & 35 & 1 \\
\hline 8984 & 404452 & 733446 & Nassau County & 43 & 48 & 4 \\
\hline 9057 & 404242 & 733422 & Nassau County & 42 & 47 & 4 \\
\hline 9078 & 404324 & 733422 & Nassau County & 60 & 65 & 4 \\
\hline 9201 & 404327 & 733359 & Nassau County & 40 & 45 & 6 \\
\hline 9222 & 404351 & 733327 & Nassau County & 40 & 45 & 6 \\
\hline 9225 & 404331 & 733308 & Nassau County & 39 & 44 & 6 \\
\hline 9234 & 404430 & 733310 & Nassau County & 200 & 205 & 6 \\
\hline 9236 & 404430 & 733310 & Nassau County & 45 & 50 & 6 \\
\hline 9239 & 404410 & 733332 & Nassau County & 200 & 205 & 6 \\
\hline 9241 & 404410 & 7333332 & Nassau County & 40 & 45 & 6 \\
\hline 9310 & 404410 & 733660 & VMI, Inc. & 180 & 230 & 12 \\
\hline 9311 & 404418 & 733702 & VMI, Inc. & 189 & 229 & 12 \\
\hline 9355 & 404337 & 733605 & Nassau County & 58 & 63 & 4 \\
\hline 9398 & 404311 & 733716 & Nassau County & 21 & 22 & 2 \\
\hline 9521 & 404411 & 733610 & Town of Hempstead & 475 & 601 & 20 \\
\hline 9703 & 404356 & 733618 & Nassau County & 96 & 106 & 4 \\
\hline 9709 & 404416 & 733521 & Town of Hempstead & 305 & 363 & 16 \\
\hline 9713 & 404356 & 733618 & Nassau County & 205 & 215 & 4 \\
\hline 9751 & 404416 & 733521 & Town of Hempstead & 125 & 286 & 16 \\
\hline 9802 & 404330 & 733530 & Nassau County & 132 & 142 & 4 \\
\hline 9803 & 404330 & 733530 & Nassau County & 54 & 59 & 4 \\
\hline 9804 & 404336 & 733509 & Nassau County & 130 & 140 & 4 \\
\hline 9805 & 404336 & 733509 & Nassau County & 53 & 58 & 4 \\
\hline
\end{tabular}


Table 6.--Data on wells in the Roosevelt Field area, Nassau County, New York (cont.)

\begin{tabular}{|c|c|c|c|c|c|c|}
\hline \multirow[b]{2}{*}{ We11 } & \multirow[b]{2}{*}{$\begin{array}{c}\text { Latitude } \\
0.1\end{array}$} & \multirow[b]{2}{*}{$\begin{array}{c}\text { Longitude } \\
\end{array}$} & \multirow[b]{2}{*}{ Owner } & \multicolumn{3}{|c|}{$\begin{array}{l}\text { Depth to screen, in } \\
\text { feet below land surface }\end{array}$} \\
\hline & & & & $\begin{array}{l}\text { Top } \\
\text { (feet) }\end{array}$ & $\begin{array}{l}\text { Bottom } \\
\text { (feet) }\end{array}$ & $\begin{array}{l}\text { Diameter } \\
\text { (inches) }\end{array}$ \\
\hline 9846 & 404412 & 733510 & Town of Hempstead & 500 & 600 & 14 \\
\hline 9914 & 404409 & 733741 & Nassau County & 49 & 54 & 4 \\
\hline 9938 & 404526 & 733335 & Nassau County & 72 & 77 & 4 \\
\hline 9939 & 404435 & 733343 & Nassau County & 66 & 71 & 4 \\
\hline 9940 & 404523 & 733634 & Nassau County & 45 & 50 & 4 \\
\hline 9941 & 404443 & 733625 & Nassau County & 42 & 47 & 4 \\
\hline 9942 & 404455 & 733814 & Nassau County & 61 & 66 & 4 \\
\hline 9943 & 404342 & 733805 & Nassau County & 61 & 66 & 4 \\
\hline 9950 & 404513 & 733534 & Nassau County & 64 & 69 & 4 \\
\hline 9951 & 404431 & 733703 & Nassau County & 38 & 54 & 4 \\
\hline 9952 & 404427 & 733704 & Nassau County & 48 & 54 & 4 \\
\hline 9953 & 404421 & 733705 & Nassau County & 48 & 54 & 4 \\
\hline 9954 & 404407 & 733704 & Nassau County & 48 & 54 & 4 \\
\hline 9955 & 404406 & 733657 & Nassau County & 48 & 54 & 4 \\
\hline 9956 & 404420 & 733644 & Nassau County & 48 & 54 & 4 \\
\hline 9957 & 404423 & 733654 & Nassau County & 48 & 54 & 4 \\
\hline 9958 & 404416 & 733654 & Nassau County & 48 & 54 & 4 \\
\hline 9959 & 404412 & 733634 & Nassau County & 48 & 54 & 4 \\
\hline 9960 & 404423 & 733639 & Nassau County & 48 & 54 & 4 \\
\hline 9961 & 404423 & 733643 & Nassau County & 48 & 54 & 4 \\
\hline 9962 & 404446 & 733724 & Nassau County & 48 & 54 & 4 \\
\hline 9963 & 404446 & 733650 & Nassau County & 48 & 54 & 4 \\
\hline 9964 & 404403 & 733706 & Nassau County & 48 & 54 & 4 \\
\hline 9965 & 404413 & 733707 & Nassau County & 48 & 54 & 4 \\
\hline 9966 & 404358 & 733656 & Nassau County & 48 & 54 & 4 \\
\hline 9967 & 404404 & 733631 & Nassau County & 48 & 54 & 4 \\
\hline 9968 & 404432 & 733712 & Nassau County & 62 & 68 & 4 \\
\hline 9971 & 404417 & 733705 & VMI, Inc. & 35 & 40 & 1 \\
\hline 9972 & 404416 & 733705 & VMI, Inc. & 35 & 40 & 1 \\
\hline 9973 & 404415 & 733705 & VMI, Inc. & 35 & 40 & 1 \\
\hline 9974 & 404410 & 733701 & VMI, Inc. & 30 & 35 & 1 \\
\hline 10019 & 404407 & 733704 & Nassau County & 223 & 228 & 4 \\
\hline 10020 & 404406 & 733657 & Nassau County & 185 & 190 & 4 \\
\hline 10033 & 404259 & 733806 & Village of Garden City & 440 & 540 & 20 \\
\hline 10034 & 404258 & 733806 & Village of Garden City & 509 & 570 & 20 \\
\hline 10035 & 404338 & 733715 & Nassau County & 48 & 53 & 4 \\
\hline 10041 & 404336 & 733509 & Nassau County & 0 & 0 & 18 \\
\hline 10042 & 404330 & 733530 & Nassau County & 0 & 0 & 18 \\
\hline 10043 & 404419 & 733616 & Georglan-Web Press, Inc. & 165 & 185 & 8 \\
\hline 10076 & 404438 & 733610 & Island Inn & 207 & 334 & 10 \\
\hline 10094 & 404416 & 733720 & Nassau County & 60 & 65 & 4 \\
\hline 10095 & 404417 & 733711 & U.S. Geological Survey & 48 & 51 & 2 \\
\hline 10096 & 404403 & 733660 & U.S. Geological Survey & 35 & 36 & 2 \\
\hline 10097 & 404359 & 733702 & U.S. Geological Survey & 35 & 36 & 2 \\
\hline 10202 & 404348 & 733724 & U.S. Geological Survey & 42 & 45 & 2 \\
\hline 10204 & 404352 & 733656 & U.S. Geological Survey & 41 & 44 & 2 \\
\hline 10205 & 404308 & 733706 & U.S. Geological Survey & 41 & 44 & 2 \\
\hline
\end{tabular}


Table 7.--Concentrations of volatile organic compounds in ground-water samples collected by Nassau County before 1989.

[Analyses by Nassau County Department of Health except where noted. All concentrations are in micrograms per 1iter.]

\begin{tabular}{|c|c|c|c|c|c|c|}
\hline $\begin{array}{c}\text { Well } \\
\text { number }\end{array}$ & Aquifer 1 & $\begin{array}{c}\text { Sampling } \\
\text { Date } \\
\text { (mo/day/yr) }\end{array}$ & $\begin{array}{c}1,2 \text {-Dichloro- } \\
\text { ethylene }\end{array}$ & $\begin{array}{c}\text { Trichloro- } \\
\text { ethylene }\end{array}$ & $\begin{array}{l}\text { Tetrachloro- } \\
\text { et hylene }\end{array}$ & $\begin{array}{l}\text { Total } \\
\text { voCs } \\
\end{array}$ \\
\hline \multirow[t]{5}{*}{1160} & G & 060280 & -- & 7 & 2 & 13 \\
\hline & & 100180 & $<30$ & 6 & 1 & 9 \\
\hline & & 022582 & $<25$ & 3 & -- & 26 \\
\hline & & 072682 & $<7$ & 1 & 24 & 27 \\
\hline & & 120182 & 1 & 1 & 35 & 39 \\
\hline \multirow[t]{4}{*}{2747} & M & 120377 & -- & $<4$ & $<2$ & e \\
\hline & & 123077 & -- & $<4$ & $<2$ & e \\
\hline & & $101783 \mathrm{P}$ & $<1$ & $<1$ & $<1$ & 7 \\
\hline & & $102083 \mathrm{P}$ & $<1$ & 2 & $<1$ & 160 \\
\hline \multirow[t]{4}{*}{2748} & M & 091180 & $<1$ & $<1$ & $<1$ & e \\
\hline & & 080481 & -- & $<4$ & $<2$ & e \\
\hline & & 090381 & $<1$ & $<1$ & $<1$ & e \\
\hline & & 012782 & $<25$ & 3 & $<1$ & 3 \\
\hline \multirow[t]{4}{*}{3699} & M & 070279 & -- & 4 & 2 & 13 \\
\hline & & 061780 & -- & 4 & 2 & 15 \\
\hline & & 061681 & $<5$ & 4 & 4 & 74 \\
\hline & & 051282 & $<25$ & 5 & 2 & 56 \\
\hline 3700 & M & 051282 & $<25$ & 3 & 2 & 13 \\
\hline \multirow[t]{5}{*}{3934} & M & 100680 & $<30$ & 11 & 4 & 20 \\
\hline & & 092380 & $<1$ & 12 & 2 & 16 \\
\hline & & 051381 & -- & 5 & 2 & 9 \\
\hline & & 101381 & $<1$ & 8 & 2 & 14 \\
\hline & & 031682 & -- & 6 & 2 & 14 \\
\hline \multirow[t]{4}{*}{3935} & M & 091179 & -- & 12 & 1 & 27 \\
\hline & & 082980 & -- & 11 & 2 & 17 \\
\hline & & 100680 & $<30$ & 14 & 5 & 24 \\
\hline & & 091581 & -- & 14 & 5 & 24 \\
\hline \multirow{14}{*}{5484} & M & 092377 & -- & $<4$ & $<2$ & e \\
\hline & & 022378 & -- & $<1$ & $<1$ & e \\
\hline & & 101978 & -- & $<1$ & $<1$ & $\epsilon$ \\
\hline & & 081679 & -- & $<5$ & $<5$ & e \\
\hline & & 091379 & - & $<5$ & $<5$ & e \\
\hline & & 022780 & -- & 3 & $<3$ & 3 \\
\hline & & 022780 & -- & 4 & $<2$ & 4 \\
\hline & & 022780 & -- & 4 & $<2$ & 4 \\
\hline & & 022980 & -- & 3 & $<3$ & 3 \\
\hline & & 061380 & -- & 4 & $<3$ & 4 \\
\hline & & 071580 & -- & 6 & $<2$ & 6 \\
\hline & & 071880 & -- & 4 & $<2$ & 4 \\
\hline & & 021781 & - & 12 & 1 & 21 \\
\hline & & 050481 & -- & 7 & $<1$ & 7 \\
\hline
\end{tabular}

$1 \quad G=$ upper glacial aquifer; $M=$ Magothy aquifer

2 e All vocs below detection limits 
Table 7.--Concentrations of volatile organic compounds in ground-water samples collected by Nassau County before 1989 (cont.)

\begin{tabular}{|c|c|c|c|c|c|c|}
\hline $\begin{array}{c}\text { We11 } \\
\text { number }\end{array}$ & Aquifer ${ }^{1}$ & $\begin{array}{c}\text { Sampling } \\
\text { Date } \\
\text { (mo/day/yr) } \\
\end{array}$ & $\begin{array}{c}\text { 1,2-Dichloro- } \\
\text { ethylene }\end{array}$ & $\begin{array}{r}\text { Trichloro- } \\
\text { ethylene }\end{array}$ & $\begin{array}{c}\text { Tetrachloro- } \\
\text { ethylene }\end{array}$ & $\begin{array}{r}\text { Total } \\
\text { VoCs } \\
\end{array}$ \\
\hline 5484 & M & 052181 & -- & 16 & 1 & 21 \\
\hline \multirow{3}{*}{$(\operatorname{cont})}$. & & 052681 & -- & 7 & $<2$ & 7 \\
\hline & & 061981 & -- & 6 & $<1$ & 9 \\
\hline & & 021782 & -- & 1 & $<1$ & 1 \\
\hline \multirow[t]{48}{*}{5485} & M & 092377 & -- & $<4$ & $<2$ & e \\
\hline & & 012678 & -- & 24 & $<2$ & 24 \\
\hline & & 022378 & -- & 43 & $<1$ & 43 \\
\hline & & 031578 & -- & 32 & $<2$ & 32 \\
\hline & & 101378 & -- & 21 & $<1$ & 24 \\
\hline & & 110678 & -- & 43 & $<1$ & 43 \\
\hline & & 120878 & -- & 39 & $<2$ & 39 \\
\hline & & 081679 & - & 60 & $<5$ & 60 \\
\hline & & 082979 & -- & 85 & $<2$ & 85 \\
\hline & & 082979 & -- & 100 & $<5$ & 100 \\
\hline & & 091079 & -- & 48 & $<3$ & 48 \\
\hline & & 091379 & -- & 85 & $<2$ & 85 \\
\hline & & 022780 & - & 46 & $<3$ & 46 \\
\hline & & 022780 & -- & 57 & $<3$ & 57 \\
\hline & & 022780 & -- & 57 & $<3$ & 61 \\
\hline & & 022780 & -- & 36 & $<2$ & 36 \\
\hline & & 022780 & -- & 37 & $<2$ & 37 \\
\hline & & 062480 & -- & 24 & $<3$ & 24 \\
\hline & & 062580 & -- & 25 & $<3$ & 25 \\
\hline & & 062680 & -- & 33 & $<3$ & 33 \\
\hline & & 070380 & -- & 24 & $<2$ & 24 \\
\hline & & 071480 & -- & 14 & $<3$ & 14 \\
\hline & & 072980 & -- & 13 & $<3$ & 13 \\
\hline & & 073080 & -- & 19 & $<2$ & 19 \\
\hline & & 073080 & -- & 15 & $<3$ & 15 \\
\hline & & 073180 & -- & 27 & $<3$ & 31 \\
\hline & & 080180 & -- & 21 & $<3$ & 21 \\
\hline & & 080480 & -- & 36 & no sample & 36 \\
\hline & & 080580 & -- & 32 & $<3$ & 32 \\
\hline & & 080780 & -- & 37 & $<3$ & 37 \\
\hline & & 081180 & -- & 48 & $<3$ & 48 \\
\hline & & 081180 & -- & 30 & $<3$ & 30 \\
\hline & & 081280 & -- & 35 & $<3$ & 35 \\
\hline & & 081480 & -- & 38 & $<3$ & 38 \\
\hline & & 081880 & -- & 42 & $<3$ & 42 \\
\hline & & 082180 & -- & 42 & $<3$ & 42 \\
\hline & & 082580 & -- & 46 & $<3$ & 46 \\
\hline & & 082580 & -- & 40 & $<3$ & 40 \\
\hline & & 082780 & -- & 53 & $<2$ & 53 \\
\hline & & 090280 & -- & 54 & $<3$ & 54 \\
\hline & & 090380 & -- & 44 & $<3$ & 44 \\
\hline & & 052181 & -- & 20 & 2 & 25 \\
\hline & & 061981 & -- & 2 & $<1$ & 6 \\
\hline & & 062281 & -- & 11 & $<1$ & 15 \\
\hline & & 063081 & -- & 10 & $<1$ & 10 \\
\hline & & 070881 & -- & 13 & $<1$ & 14 \\
\hline & & 072081 & -- & 18 & $<1$ & 18 \\
\hline & & 072781 & -- & 24 & $<1$ & 24 \\
\hline
\end{tabular}


Table 7.--Concentrations of volatile organic compounds in ground-water samples collected by Nassau County before 1989 (cont.)

\begin{tabular}{|c|c|c|c|c|c|c|}
\hline $\begin{array}{c}\text { Wel1 } \\
\text { number }\end{array}$ & Aquifer ${ }^{1}$ & $\begin{array}{c}\text { Sampling } \\
\text { Date } \\
\text { (mo/day/yr) }\end{array}$ & $\begin{array}{c}\begin{array}{l}1,2-\text {-Dichloro- } \\
\text { ethylene }\end{array} \\
\end{array}$ & $\begin{array}{r}\text { Trichloro- } \\
\text { ethylene } \\
\end{array}$ & $\begin{array}{c}\text { Tetrachloro- } \\
\text { ethylene }\end{array}$ & $\begin{array}{l}\text { Total } \\
\text { VOC's }\end{array}$ \\
\hline 5485 & M & 080481 & -- & 28 & $<1$ & 28 \\
\hline \multirow{15}{*}{$(\operatorname{cont})}$. & & 081081 & -- & 16 & $<1$ & 16 \\
\hline & & 081781 & -- & 29 & $<1$ & 31 \\
\hline & & 091081 & -- & 7 & $<1$ & 10 \\
\hline & & 092181 & -- & 29 & $<1$ & 31 \\
\hline & & 100681 & - & 19 & $<1$ & 21 \\
\hline & & 111981 & -- & 19 & $<1$ & 22 \\
\hline & & 020382 & -- & 19 & 1 & 20 \\
\hline & & 022582 & -- & 12 & $<1$ & 15 \\
\hline & & 031182 & - & 17 & $<1$ & 19 \\
\hline & & 043082 & - & 11 & $<1$ & 14 \\
\hline & & 061882 & - & 11 & $<1$ & 13 \\
\hline & & 072682 & - & 13 & $<1$ & 13 \\
\hline & & 082082 & -- & 6 & $<1$ & 6 \\
\hline & & 092382 & -- & 13 & $<1$ & 13 \\
\hline & & 102082 & - & 24 & $<1$ & 26 \\
\hline \multirow[t]{18}{*}{5486} & M & 092377 & - & 12 & 8 & 20 \\
\hline & & 012678 & -- & 15 & 8 & 32 \\
\hline & & 031578 & -- & 24 & 6 & 46 \\
\hline & & 033078 & -- & 32 & 17 & 70 \\
\hline & & 101378 & - & 88 & 8 & 113 \\
\hline & & 101878 & -- & 99 & 10 & 127 \\
\hline & & 120878 & - & 39 & $<2$ & 39 \\
\hline & & 042979 & -- & 40 & 15 & 96 \\
\hline & & 081779 & -- & 40 & 15 & 80 \\
\hline & & 082979 & -- & 76 & 7 & 96 \\
\hline & & 082979 & - & 64 & 12 & 102 \\
\hline & & 091079 & -- & 41 & 15 & 103 \\
\hline & & 091279 & -- & 41 & 15 & 97 \\
\hline & & 022980 & -- & 70 & $<3$ & 102 \\
\hline & & 022980 & -- & 68 & $<3$ & 97 \\
\hline & & 022980 & -- & 72 & $<3$ & 104 \\
\hline & & 022980 & - & 170 & 3 & 200 \\
\hline & & 022980 & -- & 150 & 3 & 170 \\
\hline \multirow[t]{5}{*}{5507} & M & 101079 & -- & 240 & 160 & 460 \\
\hline & & 072880 & -- & 300 & 190 & 590 \\
\hline & & 062381 & $<25$ & 250 & 210 & 490 \\
\hline & & 051882 & $<25$ & 360 & 240 & 630 \\
\hline & & 062083 & $<4$ & 50 & 6 & 58 \\
\hline \multirow[t]{4}{*}{5596} & M & 121879 & -- & $<4$ & $<2$ & e \\
\hline & & 101080 & - & $<4$ & $<2$ & e \\
\hline & & 020981 & - & $<4$ & $<2$ & e \\
\hline & & 050682 & - & $<1$ & $<1$ & e \\
\hline 5725 & G & 070782 & $<7$ & 32 & 5 & 38 \\
\hline
\end{tabular}

$1 \quad G=$ upper glacial aquifer; $M=$ Magothy aquifer

2 e All vocs below detection limits 
Table 7.--Concentrations of volatile organic compounds in ground-water samples collected by Nassau County before 1989 (cont.)

\begin{tabular}{|c|c|c|c|c|c|c|}
\hline $\begin{array}{c}\text { We11 } \\
\text { number }\end{array}$ & Aquifer 1 & $\begin{array}{c}\text { Sampling } \\
\text { Date } \\
\text { (mo/day/yr) }\end{array}$ & $\begin{array}{l}\text { 1,2-Dichloro- } \\
\text { ethylene }\end{array}$ & $\begin{array}{r}\text { Trichloro- } \\
\text { ethylene } \\
\end{array}$ & $\begin{array}{c}\text { Tetrachloro- } \\
\text { ethylene }\end{array}$ & $\begin{array}{l}\text { Total } \\
\text { Voc's }\end{array}$ \\
\hline \multirow[t]{4}{*}{6045} & M & 102379 & -- & 4 & 2 & 6 \\
\hline & & 072880 & -- & $<4$ & 3 & 3 \\
\hline & & 062481 & $<25$ & 4 & 4 & 8 \\
\hline & & 051982 & $<25$ & 4 & 3 & 9 \\
\hline \multirow[t]{4}{*}{6841} & M & 112179 & -- & $<4$ & $<2$ & e \\
\hline & & 072880 & - & $<4$ & $<2$ & e \\
\hline & & 062981 & $<25$ & $<1$ & 1 & 1 \\
\hline & & 052582 & $<25$ & $<1$ & $<1$ & 1 \\
\hline \multirow[t]{4}{*}{6842} & M & 112979 & - & $<4$ & 2 & 32 \\
\hline & & 072880 & -- & $<4$ & $<2$ & 27 \\
\hline & & 062381 & $<25$ & 1 & $<1$ & 22 \\
\hline & & 052582 & $<25$ & 2 & $<1$ & 20 \\
\hline 6949 & G & 070782 & $<7$ & 18 & 2 & 25 \\
\hline \multirow[t]{4}{*}{6994} & M & 101079 & - & $<4$ & $<2$ & e \\
\hline & & 072880 & -- & $<4$ & $<2$ & e \\
\hline & & 062481 & -- & 1 & 1 & 2 \\
\hline & & 051282 & $<25$ & $<1$ & $<1$ & e \\
\hline \multirow[t]{4}{*}{7174} & G & 042478 & - & 3 & 3 & 7 \\
\hline & & 031379 & -- & $<4$ & 2 & 4 \\
\hline & & 120180 & -- & $<1$ & $<1$ & 30 \\
\hline & & 011981 & $<5$ & 1 & 1 & 3 \\
\hline \multirow[t]{2}{*}{8050} & M & 062381 & 975 & 3700 & 61 & 4800 \\
\hline & & 051882 & 1500 & 2400 & 54 & 4100 \\
\hline \multirow[t]{3}{*}{8068} & M & 072980 & -- & 8 & 2 & 23 \\
\hline & & 093080 & $<30$ & 9 & 2 & 220 \\
\hline & & 060282 & $<25$ & 1 & 1 & 2 \\
\hline \multirow[t]{2}{*}{8305} & G & 060778 & - & 8 & 3 & 48 \\
\hline & & 071679 & -- & $<4$ & $<2$ & 21 \\
\hline \multirow[t]{4}{*}{8457} & M & 122178 & $<1$ & 2 & 1 & 3 \\
\hline & & 092779 & $<1$ & $<1$ & $<1$ & e \\
\hline & & 091880 & $<1$ & $<1$ & $<1$ & e \\
\hline & & 090381 & $<1$ & $<1$ & $<1$ & e \\
\hline \multirow[t]{4}{*}{8458} & M & 101079 & - & 62 & 15 & 79 \\
\hline & & 072880 & -- & 44 & 9 & 53 \\
\hline & & 062381 & $<25$ & 43 & 19 & 65 \\
\hline & & 051282 & $<25$ & 32 & 11 & 45 \\
\hline \multirow[t]{4}{*}{8474} & M & 080779 & - & $<5$ & $<5$ & e \\
\hline & & 031480 & -- & $<3$ & $<3$ & 4 \\
\hline & & 052681 & - & $<4$ & $<2$ & e \\
\hline & & 060282 & $<25$ & 1 & $<1$ & 1 \\
\hline
\end{tabular}


Table 7.--Concentrations of volatile organic compounds in ground-water samples collected by Nassau County before 1989 (cont.)

\begin{tabular}{|c|c|c|c|c|c|c|}
\hline $\begin{array}{c}\text { Well } \\
\text { number }\end{array}$ & Aquifer 1 & $\begin{array}{c}\text { Sampling } \\
\text { Date } \\
\text { (mo/day/yr) }\end{array}$ & $\begin{array}{l}\text { 1,2-Dichloro- } \\
\text { ethylent }\end{array}$ & $\begin{array}{r}\text { Trichloro- } \\
\text { ethylene }\end{array}$ & $\begin{array}{c}\text { Tetrachloro- } \\
\text { ethylene }\end{array}$ & $\begin{array}{r}\text { Total } \\
\text { VOCs } \\
\end{array}$ \\
\hline \multirow[t]{4}{*}{8475} & M & 080779 & -- & $<5$ & $<5$ & e \\
\hline & & 031480 & -- & $<3$ & $<3$ & e \\
\hline & & 052681 & -- & $<4$ & $<2$ & e \\
\hline & & 060282 & $<25$ & $<1$ & $<1$ & e \\
\hline 8666 & G & 031781 & $<5$ & 120 & 1 & 120 \\
\hline \multirow[t]{3}{*}{8682} & M & 102379 & -- & $<4$ & 4 & 9 \\
\hline & & 100880 & $<30$ & 1 & 2 & 48 \\
\hline & & 052582 & $<25$ & 1 & 1 & 8 \\
\hline \multirow{2}{*}{8753} & M & 100880 & $<30$ & 2 & 2 & 75 \\
\hline & & 052582 & $<25$ & 1 & 1 & 3 \\
\hline \multirow[t]{5}{*}{9310} & M & 120579 & -- & 9 & $<2$ & 46 \\
\hline & & 072880 & - & 29 & 2 & 63 \\
\hline & & 021781 & $<5$ & 140 & 9 & 200 \\
\hline & & $080781 P$ & $<10$ & 52 & $<2$ & 74 \\
\hline & & 051882 & $<25$ & 340 & 8 & 400 \\
\hline \multirow[t]{5}{*}{9311} & M & 120579 & -- & 930 & 2 & 930 \\
\hline & & 072880 & -- & 2200 & 6 & 2200 \\
\hline & & 021781 & $<5$ & 400 & 1 & 400 \\
\hline & & $080781 \mathrm{P}$ & 200 & 2000 & 12 & 2200 \\
\hline & & 051882 & 150 & 1300 & 3 & 1500 \\
\hline \multirow[t]{4}{*}{9355} & G & 091478 & -- & $<4$ & $<2$ & 54 \\
\hline & & 060280 & - & $<4$ & $<2$ & e \\
\hline & & 100280 & $<30$ & 1 & 4 & 22 \\
\hline & & 010782 & $<25$ & $<1$ & $<1$ & 31 \\
\hline \multirow[t]{4}{*}{9521} & M & 120280 & $<1$ & $<1$ & $<1$ & e \\
\hline & & 052681 & -- & $<4$ & $<2$ & e \\
\hline & & 020382 & - & $<1$ & $<1$ & e \\
\hline & & 021782 & -- & $<1$ & $<1$ & e \\
\hline 9914 & G & 111682 & $<1$ & 1 & $<1$ & 1 \\
\hline \multirow[t]{2}{*}{9951} & G & 070182 & $<7$ & 4 & 2 & 19 \\
\hline & & 111682 & $<1$ & 1 & $<1$ & 24 \\
\hline \multirow[t]{2}{*}{9952} & G & 063082 & $<7$ & 14 & 1 & 35 \\
\hline & & 111882 & $<1$ & 5 & $<1$ & 6 \\
\hline \multirow[t]{2}{*}{9953} & G & 062882 & $<7$ & $<1$ & $<1$ & 1 \\
\hline & & 111682 & 24 & 210 & 2 & 240 \\
\hline \multirow[t]{2}{*}{9954} & G & 061782 & 30 & 220 & 21 & 280 \\
\hline & & 111582 & 8 & 110 & 36 & 160 \\
\hline \multirow[t]{2}{*}{9955} & G & 061882 & $<7$ & 36 & 21 & 58 \\
\hline & & 111782 & 79 & 510 & 71 & 670 \\
\hline
\end{tabular}

$I G=$ upper glacial aquifer; $M=$ Magothy aquifer

2 e all vocs below detection limits 
Table 7.--Concentrations of volatile organic compounds in ground-water samples collected by Nassau County before 1989 (cont.)

\begin{tabular}{|c|c|c|c|c|c|c|}
\hline $\begin{array}{c}\text { Well } \\
\text { number }\end{array}$ & Aquiferl & $\begin{array}{c}\text { Sampling } \\
\text { Date } \\
\text { (mo/day/yr) } \\
\end{array}$ & $\begin{array}{c}\text { 1,2-Dichloro- } \\
\text { ethylene }\end{array}$ & $\begin{array}{r}\text { Trichloro- } \\
\text { ethylene } \\
\end{array}$ & $\begin{array}{c}\text { Tetrachloro- } \\
\text { ethylene }\end{array}$ & $\begin{array}{c}\text { Total } \\
\text { voC's }\end{array}$ \\
\hline \multirow[t]{2}{*}{9956} & G & 063082 & $<7$ & 17 & $<1$ & 18 \\
\hline & & 111782 & $<1$ & 5 & $<1$ & 6 \\
\hline \multirow[t]{2}{*}{9957} & G & 063082 & $<7$ & $<1$ & 1 & 1 \\
\hline & & 111782 & $<1$ & 2 & $<1$ & 2 \\
\hline \multirow[t]{2}{*}{9958} & G & 063082 & $<7$ & 1 & 1 & 3 \\
\hline & & 111782 & 5 & 11 & $<1$ & 18 \\
\hline \multirow[t]{2}{*}{9959} & G & 062982 & $<7$ & $<1$ & 1 & 3 \\
\hline & & 111582 & $<1$ & 1 & $<1$ & 2 \\
\hline \multirow[t]{2}{*}{9960} & G & 062882 & 7 & 33 & 1 & 42 \\
\hline & & 111582 & 1 & 27 & 1 & 29 \\
\hline \multirow[t]{2}{*}{9961} & G & 062982 & $<7$ & 1 & 1 & 3 \\
\hline & & 111582 & $<1$ & $<1$ & 1 & 2 \\
\hline \multirow[t]{2}{*}{9962} & G & 070882 & $<7$ & $<1$ & $<1$ & 1 \\
\hline & & 111682 & $<1$ & $<1$ & $<1$ & 21 \\
\hline \multirow[t]{2}{*}{9963} & G & 070182 & $<7$ & 10 & 4 & 26 \\
\hline & & 111682 & $<1$ & 7 & 4 & 20 \\
\hline \multirow[t]{3}{*}{9964} & G & 061882 & $<7$ & 30 & 11 & 42 \\
\hline & & 062482 & 16 & 120 & 24 & 160 \\
\hline & & 111782 & 45 & 360 & 68 & 480 \\
\hline \multirow[t]{2}{*}{9965} & G & 070882 & $<7$ & 3 & $<1$ & 3 \\
\hline & & 063082 & $<7$ & 3 & 1 & 5 \\
\hline 9966 & G & 062482 & 13 & 100 & 14 & 130 \\
\hline \multirow[t]{2}{*}{9967} & G & 062882 & $<7$ & $<1$ & 1 & 2 \\
\hline & & 111582 & $<1$ & $<1$ & $<1$ & 1 \\
\hline \multirow[t]{2}{*}{9968} & G & 111682 & $<1$ & 1 & 9 & 20 \\
\hline & & 120682 & $<1$ & $<1$ & 4 & 5 \\
\hline 9971 & G & $081381 P$ & $<5$ & 10 & $<1$ & 87 \\
\hline 9972 & G & $081381 P$ & $<5$ & 15 & $<1$ & 64 \\
\hline 9973 & G & $081381 P$ & $<5$ & $<1$ & $<1$ & e \\
\hline 9974 & G & $081381 \mathrm{P}$ & $<5$ & 50 & 2 & 70 \\
\hline 10019 & M & 111582 & 1 & 19 & 9 & 32 \\
\hline
\end{tabular}


Table 8.--Concentrations of volatile organic compounds in ground-water samples collected by U.S. Geological Survey 1989-84

[Analyses by Nassau County Department of Health, except where noted. Al1 concentrations are in micrograms per liter.]

A. WELLS

\begin{tabular}{|c|c|c|c|c|c|c|}
\hline $\begin{array}{l}\text { Well } \\
\text { number }\end{array}$ & Aquifer ${ }^{1}$ & $\begin{array}{c}\text { Sampling } \\
\text { Date } \\
\text { (mo,day,yr) }{ }^{2}\end{array}$ & $\begin{array}{c}\text { 1,2-Dichloro- } \\
\text { ethylene }\end{array}$ & $\begin{array}{r}\text { Trichloro- } \\
\text { ethylene }\end{array}$ & $\begin{array}{c}\text { Tetrachloro- } \\
\text { ethylene }\end{array}$ & $\begin{array}{l}\text { Total } \\
\text { VoCs } 3 \\
\end{array}$ \\
\hline 79 & M & $\begin{array}{l}011184 \\
040284\end{array}$ & $\begin{array}{l}<4 \\
<4\end{array}$ & $\begin{array}{l}<1 \\
<3\end{array}$ & $\begin{array}{l}<1 \\
<1\end{array}$ & $\begin{array}{l}\text { e } \\
\text { e }\end{array}$ \\
\hline 80 & M & 011184 & $<4$ & $<1$ & $<1$ & e \\
\hline 81 & M & 111484 & $<15$ & $<1$ & $<1$ & e \\
\hline 82 & M & 011184 & $<4$ & $<1$ & $<1$ & e \\
\hline 83 & M & 040284 & $<4$ & 29 & 15 & 44 \\
\hline 95 & M & 070384 & $<5$ & $<1$ & $<1$ & e \\
\hline 97 & M & $\begin{array}{l}060484 \\
111384\end{array}$ & $\begin{array}{l}<5 \\
<15\end{array}$ & $\begin{array}{l}<1 \\
<1\end{array}$ & $\begin{array}{l}<1 \\
<1\end{array}$ & $\begin{array}{l}\text { e } \\
\text { e }\end{array}$ \\
\hline 101 & M & 112684 & $<15$ & $<1$ & 6 & 6 \\
\hline 1139 & G & 050884 & $<5$ & 8 & 1 & 14 \\
\hline 1141 & G & 050884 & $<5$ & $<1$ & $<1$ & e \\
\hline 1160 & G & $\begin{array}{l}082583 \\
082583 \mathrm{~N} \\
041984 \\
041984 \mathrm{~N}\end{array}$ & $\begin{array}{l}<4 \\
<1 \\
<4 \\
<3\end{array}$ & $\begin{array}{r}3 \\
4 \\
<3 \\
<3\end{array}$ & $\begin{array}{r}7 \\
15 \\
3 \\
3\end{array}$ & $\begin{array}{l}43 \\
70 \\
56 \\
92\end{array}$ \\
\hline 1451 & G & 050384 & $<4$ & $<3$ & $<1$ & e \\
\hline 1697 & M & 070284 & $<5$ & $<1$ & $<1$ & e \\
\hline 2748 & M & $\begin{array}{l}080383 \\
041184\end{array}$ & $\begin{array}{l}<4 \\
<4\end{array}$ & $\begin{array}{l}<1 \\
<3\end{array}$ & $\begin{array}{l}<1 \\
<1\end{array}$ & $\begin{array}{l}\text { e } \\
\text { e }\end{array}$ \\
\hline 3185 & M & 051084 & $<5$ & 3 & 4 & 13 \\
\hline 3699 & M & $\begin{array}{l}080983 \\
050184\end{array}$ & $\begin{array}{l}<4 \\
<4\end{array}$ & $\begin{array}{r}2 \\
<3\end{array}$ & $\begin{array}{l}5 \\
2\end{array}$ & $\begin{array}{l}19 \\
10\end{array}$ \\
\hline 3700 & M & $\begin{array}{l}082283 \\
041884\end{array}$ & $\begin{array}{l}<4 \\
<4\end{array}$ & $\begin{array}{r}4 \\
<3\end{array}$ & $\begin{array}{l}2 \\
2\end{array}$ & $\begin{array}{r}14 \\
6\end{array}$ \\
\hline 3934 & M & $\begin{array}{l}082483 \\
041384\end{array}$ & $\begin{array}{l}<4 \\
<4\end{array}$ & $\begin{array}{r}9 \\
17\end{array}$ & $\begin{array}{l}1 \\
2\end{array}$ & $\begin{array}{l}13 \\
22\end{array}$ \\
\hline
\end{tabular}

l G = upper glacial aquifer; $M=$ Magothy aquifer

2 Analyses from same well on same date are of duplicate samples

$\mathbf{N}$ = analysis by National Water Quality Laboratory, At lanta, Ga.

$3 \mathrm{e}=$ all volatile organic compounds below detection limits 
Table 8.--Concentrations of volatile organic compounds in ground-water samples collected by U.S. Geological Survey 1989-84 (cont.)

A. WELLS (continued)

\begin{tabular}{|c|c|c|c|c|c|c|}
\hline $\begin{array}{c}\text { Well } \\
\text { number }\end{array}$ & Aquifer 1 & 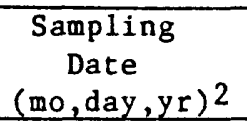 & $\begin{array}{l}\text { 1,2-Dichloro- } \\
\text { ethylene }\end{array}$ & $\begin{array}{r}\text { Trichloro- } \\
\text { ethylene } \\
\end{array}$ & $\begin{array}{c}\text { Tetrachloro- } \\
\text { ethylene }\end{array}$ & $\begin{array}{l}\text { Total } \\
\text { VoCs } 3 \\
\end{array}$ \\
\hline \multirow[t]{2}{*}{3935} & M & 082483 & $<4$ & 15 & 2 & 24 \\
\hline & & 041184 & $<4$ & 18 & 3 & 27 \\
\hline \multirow[t]{2}{*}{4082} & $M$ & 060484 & $<5$ & $<1$ & $<1$ & 1 \\
\hline & & 120784 & $<15$ & $<1$ & $<1$ & e \\
\hline 4206 & M & 060484 & $<5$ & $<1$ & $<1$ & e \\
\hline 4425 & M & 111484 & $<15$ & 19 & 8 & 27 \\
\hline 4772 & G & 042084 & $<4$ & $<3$ & $<1$ & e \\
\hline \multirow[t]{2}{*}{5484} & M & 081083 & $<4$ & 8 & $<1$ & 8 \\
\hline & & 040684 & $<4$ & 11 & 1 & 13 \\
\hline \multirow[t]{2}{*}{5485} & M & 090783 & 5 & -- & 1 & 6 \\
\hline & & 041284 & $<4$ & 22 & $<1$ & 26 \\
\hline \multirow[t]{5}{*}{5507} & M & 080383 & 10 & 260 & 170 & 470 \\
\hline & & $080383 \mathrm{~N}$ & 6 & 240 & 160 & 430 \\
\hline & & 041884 & $<4$ & 440 & 140 & 600 \\
\hline & & $041884 \mathrm{~N}$ & 6 & 330 & 140 & 510 \\
\hline & & 080784 & $<4$ & 380 & 350 & 840 \\
\hline \multirow[t]{2}{*}{5596} & M & 080383 & $<4$ & $<1$ & $<1$ & e \\
\hline & & 041384 & $<4$ & $<3$ & $<1$ & e \\
\hline \multirow[t]{2}{*}{5725} & G & 080383 & 7 & 49 & 7 & 65 \\
\hline & & 051184 & 3 & 140 & 14 & 170 \\
\hline \multirow[t]{5}{*}{6045} & $M$ & 080983 & $<4$ & 3 & 3 & 6 \\
\hline & & $080983 \mathrm{~N}$ & 3 & 7 & $<1$ & 10 \\
\hline & & 042384 & $<4$ & 5 & 4 & 9 \\
\hline & & $042384 \mathrm{~N}$ & $<3$ & 5 & 3 & 8 \\
\hline & & 080784 & $<4$ & 3 & 3 & 6 \\
\hline 6315 & M & 041184 & $<4$ & $<3$ & $<1$ & e \\
\hline \multirow[t]{2}{*}{6842} & $M$ & 082283 & $<4$ & 5 & $<1$ & 32 \\
\hline & & 042384 & $<4$ & 3 & $<1$ & 9 \\
\hline \multirow[t]{2}{*}{6949} & G & 080383 & 11 & 51 & 7 & 7 \\
\hline & & 051184 & $<5$ & 12 & 3 & 38 \\
\hline 7298 & M & 111484 & $<15$ & $<1$ & $<1$ & e \\
\hline 7500 & $M$ & 041284 & $<4$ & $<3$ & $<1$ & e \\
\hline 7785 & M & 112684 & $<15$ & $<1$ & $<1$ & e \\
\hline \multirow[t]{2}{*}{7957} & M & 081083 & $<4$ & $<1$ & $<1$ & 1 \\
\hline & & 041284 & $<4$ & $<3$ & $<1$ & e \\
\hline
\end{tabular}


Table 8.--Concentrations of volatile organic compounds in ground-water samples collected by U.S. Geological Survey 1989-84 (cont.)

A. WELLS (continued)

\begin{tabular}{|c|c|c|c|c|c|c|}
\hline $\begin{array}{l}\text { Well } \\
\text { number }\end{array}$ & Aquifer ${ }^{1}$ & $\begin{array}{c}\text { Sampling } \\
\text { Date } \\
\text { (mo,day,yr) }{ }^{2} \\
\end{array}$ & $\begin{array}{l}\text { 1,2-Dichloro- } \\
\text { ethylene }\end{array}$ & $\begin{array}{r}\text { Trichloro- } \\
\text { ethylene }\end{array}$ & $\begin{array}{c}\text { Tetrachloro- } \\
\text { ethylene }\end{array}$ & $\begin{array}{l}\text { Total } \\
\text { VoCs } 3 \\
\end{array}$ \\
\hline \multirow[t]{2}{*}{8007} & M & 042384 & $<4$ & $<3$ & $<1$ & e \\
\hline & & 082084 & $<5$ & $<1$ & $<1$ & e \\
\hline \multirow[t]{4}{*}{8050} & M & 080483 & 720 & 2100 & 34 & 2900 \\
\hline & & $\begin{array}{l}080483 \mathrm{~N} \\
050284\end{array}$ & $\begin{array}{l}1400 \\
2800\end{array}$ & $\begin{array}{l}13000 \\
38000\end{array}$ & $\begin{array}{l}36 \\
87\end{array}$ & $\begin{array}{l}14000 \\
41000\end{array}$ \\
\hline & & $050284 \mathrm{~N}$ & 2500 & 23000 & 77 & 26000 \\
\hline & & 080784 & 1100 & 13000 & 47 & 14000 \\
\hline \multirow{2}{*}{8068} & M & 080983 & 8 & 14 & 4 & 42 \\
\hline & & 042384 & 4 & 15 & 3 & 27 \\
\hline \multirow[t]{2}{*}{8457} & M & 080383 & $<4$ & $<1$ & $<1$ & e \\
\hline & & 041184 & $<4$ & $<3$ & $<1$ & e \\
\hline \multirow[t]{3}{*}{8458} & M & 080983 & 9 & 51 & 19 & 84 \\
\hline & & 042684 & $<4$ & 39 & 16 & 60 \\
\hline & & 080784 & $<4$ & 37 & 2 & 64 \\
\hline \multirow{2}{*}{8474} & M & 081083 & $<4$ & $<1$ & $<1$ & e \\
\hline & & 041184 & $<4$ & $<3$ & $<1$ & e \\
\hline \multirow{2}{*}{8475} & M & 081083 & $<4$ & $<1$ & $<1$ & e \\
\hline & & 040684 & $<4$ & $<3$ & $<1$ & e \\
\hline 8576 & M & 041384 & $<4$ & $<3$ & 2 & 2 \\
\hline 8598 & G & 050784 & $<5$ & $<1$ & $<1$ & e \\
\hline \multirow[t]{3}{*}{8666} & G & 080883 & 92 & 450 & 2 & 550 \\
\hline & & $080883 \mathrm{~N}$ & 140 & 580 & 7 & 740 \\
\hline & & 042484 & 84 & 540 & 2 & 630 \\
\hline 8682 & M & 082483 & $<4$ & 6 & 3 & 67 \\
\hline \multirow[t]{2}{*}{8753} & M & 082483 & $<4$ & 5 & 1 & 29 \\
\hline & & 051084 & $<5$ & 1 & 1 & 11 \\
\hline \multirow[t]{2}{*}{8958} & G & 050184 & $<4$ & $<3$ & $<1$ & 2 \\
\hline & & $050184 \mathrm{~N}$ & $<3$ & $<3$ & $<3$ & e \\
\hline 8971 & G & 051484 & $<5$ & $<1$ & $<1$ & e \\
\hline 8984 & G & 051684 & $<5$ & $<1$ & $<1$ & 4 \\
\hline 9057 & G & 051784 & $<5$ & $<1$ & $<1$ & 4 \\
\hline 9078 & G & 051684 & $<5$ & $<1$ & $<1$ & 6 \\
\hline $\begin{array}{ll}1 & G= \\
2 & \text { Anc } \\
N & \text { an } \\
3 & e=c\end{array}$ & $\begin{array}{l}\text { pper gla } \\
\text { ses frou } \\
\text { sis by N } \\
\text { volatil }\end{array}$ & $\begin{array}{l}\text { al aquifer; } \\
\text { ame well on } \\
\text { ional Water } \\
\text { organic comp }\end{array}$ & $\begin{array}{l}M=\text { Magothy a } \\
\text { same date are } \\
\text { Quality Labor } \\
\text { pounds below d }\end{array}$ & $\begin{array}{l}\text { duplicate } \\
\text { ry, At lanta } \\
\text { ction limit }\end{array}$ & $\begin{array}{l}\text { amples } \\
\text { Ga. }\end{array}$ & \\
\hline
\end{tabular}


Table 8.--Concentrations of volatile organic compounds in ground-water samples collected by U.S. Geological Survey 1989-84 (cont.)

A. WELLS (continued)

\begin{tabular}{|c|c|c|c|c|c|c|}
\hline $\begin{array}{c}\text { Well } \\
\text { number }\end{array}$ & Aquifer ${ }^{1}$ & $\begin{array}{l}\text { Sampling } \\
\text { Date } \\
\text { (mo,day,yr) }{ }^{2} \\
\end{array}$ & $\begin{array}{l}1,2 \text {-Dichloro- } \\
\text { ethylene }\end{array}$ & $\begin{array}{r}\text { Trichloro- } \\
\text { ethylene }\end{array}$ & $\begin{array}{c}\text { Tetrachloro- } \\
\text { ethylene }\end{array}$ & $\begin{array}{l}\text { Total } \\
\text { Vocs } 3 \\
\end{array}$ \\
\hline \multirow[t]{3}{*}{9310} & M & 080983 & 42 & 370 & 11 & 450 \\
\hline & & $\begin{array}{l}042684 \\
042684 \mathrm{~N}\end{array}$ & $\begin{array}{l}120 \\
160\end{array}$ & $\begin{array}{r}1300 \\
950\end{array}$ & $\begin{array}{r}12 \\
9\end{array}$ & $\begin{array}{l}1500 \\
1200\end{array}$ \\
\hline & & 080884 & 73 & 810 & 19 & 930 \\
\hline \multirow[t]{5}{*}{9311} & M & 080983 & 190 & 990 & 4 & 1200 \\
\hline & & $080983 \mathrm{~N}$ & 490 & 2800 & 10 & 3300 \\
\hline & & 041984 & 78 & 550 & 2 & 630 \\
\hline & & $041984 \mathrm{~N}$ & 97 & 450 & $<3$ & 550 \\
\hline & & 080884 & 530 & 3000 & 10 & 3500 \\
\hline \multirow[t]{2}{*}{9355} & G & 043084 & $<4$ & $<3$ & $<1$ & 3 \\
\hline & & $043084 \mathrm{~N}$ & $<3$ & $<3$ & $<3$ & e \\
\hline 9398 & G & 091984 & no sample & $<1$ & $<1$ & e \\
\hline \multirow[t]{2}{*}{9521} & M & 081083 & $<4$ & $<1$ & $<1$ & e \\
\hline & & 040684 & $<4$ & $<3$ & $<1$ & e \\
\hline 9703 & M & 051484 & 260 & 18 & 36 & 520 \\
\hline \multirow[t]{2}{*}{9709} & M & 083083 & $<4$ & 2 & $<1$ & 2 \\
\hline & & 041784 & $<4$ & $<3$ & $<1$ & e \\
\hline 9713 & M & 051484 & $<5$ & $<1$ & $<1$ & e \\
\hline \multirow[t]{2}{*}{9751} & M & 083083 & $<4$ & 4 & 4 & 4 \\
\hline & & 050184 & $<4$ & $<3$ & $<1$ & e \\
\hline 9802 & M & 051584 & $<5$ & 2 & $<1$ & 35 \\
\hline 9803 & G & 050284 & $<4$ & 51 & 26 & 400 \\
\hline 9804 & $M$ & 051684 & $<5$ & $<1$ & $<1$ & e \\
\hline 9805 & G & 050284 & $<4$ & 3 & $<1$ & 4 \\
\hline \multirow[t]{2}{*}{9846} & M & 081083 & $<4$ & 1 & $<1$ & 1 \\
\hline & & 051084 & $<5$ & $<1$ & $<1$ & e \\
\hline \multirow[t]{2}{*}{9914} & G & 082983 & $<4$ & 3 & $<1$ & 3 \\
\hline & G & 040384 & $<4$ & $<3$ & $<1$ & e \\
\hline 9940 & G & 041084 & $<4$ & $<3$ & $<1$ & e \\
\hline \multirow[t]{2}{*}{9941} & G & 082983 & $<4$ & 2 & 2 & 16 \\
\hline & & 040684 & $<4$ & $<3$ & 2 & 8 \\
\hline 9942 & G & 041084 & $<4$ & $<3$ & 1 & 1 \\
\hline 9943 & G & 041084 & $<4$ & 5 & $<1$ & 6 \\
\hline
\end{tabular}


Table 8.--Concentrations of volatile organic compounds in ground-water samples collected by U.S. Geological Survey 1989-84 (cont.)

A. WELLS (continued)

\begin{tabular}{|c|c|c|c|c|c|c|}
\hline $\begin{array}{c}\text { Well } \\
\text { number }\end{array}$ & Aquifer 1 & $\begin{array}{c}\text { Sampling } \\
\text { Date } \\
\text { (mo, day,yr) }{ }^{2} \\
\end{array}$ & $\begin{array}{c}\text { 1, 2-Dichloro- } \\
\text { ethylene }\end{array}$ & $\begin{array}{r}\text { Trichloro- } \\
\text { ethylene }\end{array}$ & $\begin{array}{c}\text { Tetrachloro- } \\
\text { et hylene }\end{array}$ & $\begin{array}{l}\text { Total } \\
\text { voCs } \\
\end{array}$ \\
\hline 9950 & $G$ & 050284 & $<4$ & $<3$ & 3 & 7 \\
\hline \multirow{4}{*}{9951.1} & G & 080283 & $<4$ & 4 & 1 & 1000 \\
\hline & & $080283 \mathrm{~N}$ & $<1$ & $<1$ & $<1$ & e \\
\hline & & 101883 & $<4$ & 4 & 2 & \\
\hline & & $101883 \mathrm{~N}$ & $<3$ & 7 & 4 & 1200 \\
\hline \multirow[t]{2}{*}{9951.2} & G & 043084 & $<4$ & $<3$ & $<1$ & 5 \\
\hline & & $043084 \mathrm{~N}$ & $<3$ & $<3$ & $<3$ & e \\
\hline \multirow{3}{*}{9952.1} & G & 080483 & $<4$ & 8 & $<1$ & 9 \\
\hline & & 102083 & $<4$ & 6 & $<1$ & \\
\hline & & $102083 \mathrm{~N}$ & $<3$ & 10 & $<3$ & 10 \\
\hline \multirow[t]{2}{*}{9952.2} & G & 042384 & $<4$ & $<3$ & $<1$ & e \\
\hline & & $042384 \mathrm{~N}$ & $<3$ & 4 & $<3$ & 4 \\
\hline \multirow[t]{2}{*}{9953} & G & 080483 & 84 & 480 & 3 & 570 \\
\hline & & $\begin{array}{l}043084 \\
043084 \mathrm{~N}\end{array}$ & $\begin{array}{r}<4 \\
5\end{array}$ & $\begin{array}{r}56 \\
200\end{array}$ & $\begin{array}{r}3 \\
<3\end{array}$ & $\begin{array}{r}64 \\
210\end{array}$ \\
\hline \multirow[t]{6}{*}{9954} & $G$ & 080283 & 61 & 480 & 50 & 600 \\
\hline & & $080283 \mathrm{~N}$ & $<1$ & 9 & 3 & 240 \\
\hline & & $120183 \mathrm{~N}$ & 10 & 84 & 34 & 130 \\
\hline & & 041784 & $<4$ & 92 & 31 & 130 \\
\hline & & $041784 \mathrm{~N}$ & 4 & 69 & 28 & 100 \\
\hline & & $071984 \mathrm{~N}$ & 39 & 310 & 56 & 410 \\
\hline \multirow[t]{2}{*}{9955} & G & 080483 & 5 & 5 & 2 & 12 \\
\hline & & 042484 & 24 & 440 & 77 & 560 \\
\hline \multirow[t]{2}{*}{9956} & G & 080583 & $<4$ & 5 & $<1$ & 6 \\
\hline & & 041684 & $<4$ & 8 & $<1$ & 8 \\
\hline \multirow[t]{2}{*}{9957} & G & 080583 & $<4$ & 1 & $<1$ & 2 \\
\hline & & 042484 & $<4$ & $<3$ & $<1$ & e \\
\hline \multirow[t]{2}{*}{9958} & G & 080583 & $<4$ & 1 & $<1$ & 1 \\
\hline & & 041284 & $<4$ & $<3$ & $<1$ & e \\
\hline \multirow[t]{2}{*}{9959} & G & 081183 & $<4$ & $<1$ & $<4$ & e \\
\hline & & 040684 & $<4$ & $<3$ & $<1$ & e \\
\hline \multirow[t]{2}{*}{9960} & G & 081183 & $<4$ & 10 & $<4$ & 10 \\
\hline & & 040984 & $<4$ & 5 & 1 & 28 \\
\hline \multirow[t]{2}{*}{9961} & G & 081183 & $<4$ & $<1$ & $<4$ & e \\
\hline & & 040984 & $<4$ & $<3$ & 1 & 2 \\
\hline
\end{tabular}

$1 G=$ upper glacial aquifer; $M=$ Magothy aquifer

2 Analyses from same well on same date are of duplicate samples

$\mathrm{N}=$ analysis by National Water Quality Laboratory Atlanta, Ga.

3 e=all volatile organic compounds below detection limits 
Table 8.--Concentrations of volatile organic compounds in ground-water samples collected by U.S. Geological Survey 1989-84 (cont.)

A. WELLS (continued)

\begin{tabular}{|c|c|c|c|c|c|c|}
\hline $\begin{array}{c}\text { Well } \\
\text { number }\end{array}$ & Aquifer 1 & $\begin{array}{l}\text { Sampling } \\
\text { Date } \\
\text { (mo,day,yr) }{ }^{2} \\
\end{array}$ & $\begin{array}{l}\begin{array}{l}\text { 1,2-Dichloro- } \\
\text { ethylene }\end{array} \\
\end{array}$ & $\begin{array}{r}\text { Trichloro- } \\
\text { ethylene } \\
\end{array}$ & $\begin{array}{c}\text { Tetrachloro- } \\
\text { ethyle }{ }^{n_{e}}\end{array}$ & $\begin{array}{l}\text { Total } \\
\text { VOCs }\end{array}$ \\
\hline \multirow[t]{2}{*}{9962} & ri & 081583 & $<4$ & $<1$ & $<1$ & 10 \\
\hline & & 040984 & $<4$ & $<3$ & $<1$ & 1 \\
\hline \multirow[t]{2}{*}{9963} & G & 081583 & $<4$ & 6 & 2 & 8 \\
\hline & & 041684 & $<4$ & $<3$ & 2 & 6 \\
\hline \multirow[t]{4}{*}{9964} & G & 080883 & 62 & 290 & 50 & 410 \\
\hline & & $080883 \mathrm{~N}$ & 83 & 360 & 67 & 520 \\
\hline & & 041984 & $<4$ & 20 & 7 & 27 \\
\hline & & $041984 \mathrm{~N}$ & $<3$ & 16 & 8 & 24 \\
\hline \multirow[t]{3}{*}{9965.1} & G & 080483 & 120 & 670 & 4 & 800 \\
\hline & & 101883 & 83 & 370 & 2 & \\
\hline & & $101883 \mathrm{~N}$ & 170 & 530 & 5 & 710 \\
\hline \multirow[t]{2}{*}{9965.2} & G & 042384 & 70 & 320 & 1 & 390 \\
\hline & & $042384 \mathrm{~N}$ & $<3$ & 270 & $<3$ & 270 \\
\hline \multirow[t]{3}{*}{9966} & G & 080883 & 40 & 320 & 55 & 430 \\
\hline & & 041684 & $<4$ & 3 & 1 & 4 \\
\hline & & 080784 & 28 & 350 & 97 & 510 \\
\hline \multirow{2}{*}{9967} & G & 081183 & $<4$ & 1 & 2 & 3 \\
\hline & & 040984 & $<4$ & $<3$ & $<1$ & e \\
\hline \multirow[t]{2}{*}{9968} & G & 081583 & $<4$ & 5 & 3 & 11 \\
\hline & & 040684 & $<4$ & $<3$ & 2 & 4 \\
\hline \multirow[t]{2}{*}{9971} & G & 050884 & $<5$ & 29 & 1 & 32 \\
\hline & & 080884 & 130 & 560 & 3 & 700 \\
\hline \multirow[t]{2}{*}{9972} & G & 050884 & 82 & 440 & 2 & 530 \\
\hline & & 080884 & 100 & 360 & $<4$ & 460 \\
\hline \multirow[t]{2}{*}{9973} & G & 050884 & 140 & 750 & 2 & 890 \\
\hline & & 080884 & 130 & 550 & 5 & 690 \\
\hline \multirow{2}{*}{9974} & G & 050784 & $<5$ & 2 & $<1$ & 2 \\
\hline & & 080884 & $<4$ & 1 & $<4$ & 1 \\
\hline \multirow[t]{3}{*}{10019} & M & 081683 & $<4$ & 19 & 8 & 30 \\
\hline & & 051484 & $<5$ & 29 & 12 & 50 \\
\hline & & $051484 \mathrm{~N}$ & 7 & 23 & 12 & 42 \\
\hline \multirow[t]{2}{*}{10020} & M & 083083 & 24 & 170 & 24 & 220 \\
\hline & & 050984 & 9 & 150 & 20 & 190 \\
\hline 10033 & M & 051584 & $<5$ & $<1$ & $<1$ & e \\
\hline 10034 & M & 101584 & $<10$ & $<1$ & $<1$ & 4 \\
\hline
\end{tabular}


Table 8.--Concentrations of volatile organic compounds in ground-water samples collected by U.S. Geological Survey 1989-84 (cont.)

A. WELLS (continued)

\begin{tabular}{|c|c|c|c|c|c|c|}
\hline $\begin{array}{c}\text { Well } \\
\text { number }\end{array}$ & Aquifer ${ }^{1}$ & $\begin{array}{l}\text { Sampling } \\
\text { Date } \\
\text { (mo,day,yr) }{ }^{2} \\
\end{array}$ & $\begin{array}{c}\text { 1,2-Dichloro- } \\
\text { ethylene }\end{array}$ & $\begin{array}{r}\text { Trichloro- } \\
\text { ethylene } \\
\end{array}$ & $\begin{array}{c}\text { Tetrachloro- } \\
\text { et hylene }\end{array}$ & $\begin{array}{l}\text { Total } \\
\text { VOCs } 3 \\
\end{array}$ \\
\hline \multirow[t]{8}{*}{10035} & G & 082583 & 16 & 72 & 8 & 98 \\
\hline & & $082583 \mathrm{~N}$ & 18 & 92 & 13 & 120 \\
\hline & & $121383 \mathrm{~N}$ & 36 & 85 & 11 & 130 \\
\hline & & $022184 \mathrm{~N}$ & 29 & 79 & 12 & 120 \\
\hline & & 041184 & 7 & 70 & 9 & 86 \\
\hline & & $041184 \mathrm{~N}$ & 23 & 63 & 11 & 97 \\
\hline & & $060484 \mathrm{~N}$ & 11 & 56 & 13 & 80 \\
\hline & & $080284 \mathrm{~N}$ & $<3$ & 31 & 10 & 34 \\
\hline \multirow[t]{2}{*}{10043} & M & 080983 & $<4$ & 2 & 2 & 8 \\
\hline & & 041784 & $<4$ & $<3$ & 1 & 9 \\
\hline \multirow[t]{2}{*}{10076} & M & 082283 & $<4$ & 2 & $<1$ & 7 \\
\hline & & 042384 & $<4$ & $<3$ & $<1$ & e \\
\hline \multirow[t]{2}{*}{10094} & G & 093083 & $<4$ & $<1$ & $<1$ & e \\
\hline & & 040384 & $<4$ & $<3$ & $<1$ & e \\
\hline \multirow[t]{2}{*}{10095.1} & G & 093083 & $<4$ & 1 & 5 & 7 \\
\hline & $G$ & 101983 & $<4$ & 2 & 4 & 6 \\
\hline 10095.2 & G & 041684 & 34 & 280 & 2 & 320 \\
\hline \multirow[t]{3}{*}{10096.1} & G & 082583 & 80 & 300 & 44 & 430 \\
\hline & & $082583 \mathrm{~N}$ & 140 & 400 & 550 & 1100 \\
\hline & & 102083 & 32 & 220 & 36 & \\
\hline \multirow[t]{4}{*}{10096.2} & G & 050184 & $<4$ & 19 & 1 & 21 \\
\hline & & $050184 \mathrm{~N}$ & $<3$ & 16 & $<3$ & 16 \\
\hline & & $072684 \mathrm{~N}$ & 130 & 300 & 74 & 520 \\
\hline & & 080784 & 40 & 370 & 110 & 540 \\
\hline \multirow[t]{2}{*}{10097.1} & G & 081783 & 45 & 250 & 39 & 340 \\
\hline & & $111583 \mathrm{~N}$ & 38 & 260 & 45 & 340 \\
\hline \multirow[t]{4}{*}{10097.2} & G & 050784 & $<5$ & 2 & $<1$ & 2 \\
\hline & & $070284 \mathrm{~N}$ & 16 & 170 & 44 & 230 \\
\hline & & 080784 & 17 & 300 & 80 & 450 \\
\hline & & 091984 & 25 & 270 & 100 & 400 \\
\hline 10202 & G & 050784 & $<5$ & 4 & $<1$ & 4 \\
\hline 10204 & G & 041384 & 10 & 210 & 30 & 260 \\
\hline
\end{tabular}

$\bar{l} G=$ upper glacial aquifer; $M=$ Magothy aquifer

2 Analyses from same well on same date are of duplicate samples

$\mathbf{N}=$ analysis by National Water Quality Laboratory, At lanta, Ga.

$3 e=a l l$ volatile organic compounds below detection limits 
Table 8.--Concentrations of volatile organic compounds in ground-water samples collected by U.S. Geological Survey 1989-84 (cont.)

A. WELLS (continued)

\begin{tabular}{|c|c|c|c|c|c|c|}
\hline $\begin{array}{c}\text { Well } \\
\text { number }\end{array}$ & Aquiferl & $\begin{array}{c}\text { Sampling } \\
\text { Date } \\
\left(\text { mo,day,yr) }{ }^{2}\right. \\
\end{array}$ & $\begin{array}{l}\text { 1,2-Dichloro- } \\
\text { ethylene }\end{array}$ & $\begin{array}{r}\text { Trichloro- } \\
\text { ethylene } \\
\end{array}$ & $\begin{array}{c}\text { Tetrachloro- } \\
\text { ethylene }\end{array}$ & $\begin{array}{l}\text { Total } \\
\text { VoC's } 3 \\
\end{array}$ \\
\hline 10205 & G & $\begin{array}{l}041384 \\
050984 \mathrm{~N} \\
060784 \mathrm{~N} \\
071284 \mathrm{~N}\end{array}$ & $\begin{array}{l}12 \\
41 \\
63 \\
15\end{array}$ & $\begin{array}{l}81 \\
72 \\
94 \\
48\end{array}$ & $\begin{array}{r}65 \\
59 \\
100 \\
33\end{array}$ & $\begin{array}{r}160 \\
170 \\
260 \\
96\end{array}$ \\
\hline \multicolumn{7}{|c|}{$\begin{array}{c}1 \\
2 \\
3 \\
*_{N}=\end{array}$} \\
\hline Sitel & & $\begin{array}{c}\text { Sampling } \\
\text { Date } \\
\text { (mo-day-yr) }\end{array}$ & $\begin{array}{c}\text { 1,2-Dichloro- } \\
\text { ethylene }\end{array}$ & $\begin{array}{c}\text { Trichloro- } \\
\text { ethylene }\end{array}$ & $\begin{array}{c}\text { Tetrachloro- } \\
\text { ethylene }\end{array}$ & $\begin{array}{r}\text { Total } \\
\text { VOCs } \\
\end{array}$ \\
\hline$P R B$ in & & $\begin{array}{l}090783 \\
080784\end{array}$ & $\begin{array}{l}47 \\
41\end{array}$ & $\begin{array}{l}410 \\
600\end{array}$ & $\begin{array}{r}61 \\
150\end{array}$ & $\begin{array}{l}530 \\
840\end{array}$ \\
\hline PRB mid & & 080784 & 24 & 380 & 120 & 570 \\
\hline NCB 124 & & $\begin{array}{l}090783 \\
080784\end{array}$ & $\begin{array}{l}24 \\
17\end{array}$ & $\begin{array}{l}230 \\
340\end{array}$ & $\begin{array}{r}50 \\
100\end{array}$ & $\begin{array}{l}310 \\
490\end{array}$ \\
\hline NCB 167 & & 090783 & $<4$ & -- & 1 & 1 \\
\hline Aerator & $(\text { in })^{2}$ & 080884 & 270 & 1800 & 15 & 2100 \\
\hline Aerator & $(\text { out })^{2}$ & 080884 & 130 & 1000 & 3 & 1100 \\
\hline
\end{tabular}

1 PRB = Pembrook recharge basin. In = inflow to first basin; mid = midpoint $=$ flow to second basin

$\mathrm{NCB}=$ Nassau County basin (sampled at inflow) and basin \#

2 Aerator $=$ treatment system for wells N9310 and N9311.

In = inlet; out = outlet 